\title{
HISTORIA DE UNA INVENCIÓN: REALIDAD Y FICCIÓN DEL SUPUESTO AUTORRETRATO DEL MAESTRO MATEO EN EL PÓRTICO DE LA GLORIA*
}

\author{
Alfredo Vigo Trasancos \\ Universidade de Santiago de Compostela
}

Data recepción: 2017/01/10

Data aceptación: 2017/04/18

Contacto autor: alfredomanuel.vigo@usc.es

ORCID: https://orcid.org/0000-0001-6932-8627

\section{RESUMEN}

La historiografía decimonónica difundió la opinión de que la figura arrodillada que se encuentra en la parte posterior del parteluz del Pórtico de la Gloria, en la catedral de Santiago, era un retrato o representación del Maestro Mateo, añadiendo además que, en la cartela que lleva en su mano izquierda, aparecía escrita la palabra "ARCHITECTUS", hoy borrada. Sin duda se trata de una falsedad histórica que este artículo pretende demostrar, proponiendo asimismo una interpretación muy diferente del que, popularmente, se conoce también como "Santo dos Croques".

Palabras clave: Pórtico de la Gloria, Maestro Mateo, Santo dos Croques, Architectus, Hércules, Fernando II de León, España, Galicia, Catedral de Santiago de Compostela, siglo XII, siglo XIX

\section{ABSTRACT}

Nineteenth-century historiography was responsible for spreading the belief that the kneeling figure situated at the rear of the mullion of the Pórtico de la Gloria, in Santiago Cathedral, was an image or representation of Maestro Mateo. It also put forward the idea that the small placard he holds in his left hand, which is free of any inscription, once bore the word "ARCHITECTUS". This is, without question, a historical falsehood, as this paper attempts to demonstrate, while also providing a very different interpretation of a figure that is also popularly known as "Santo dos Croques" ("the saint of the head bumps").

Keywords: Pórtico de la Gloria, Maestro Mateo, Santo dos Croques, Architectus, Hercules, Ferdinand II of León, Spain, Galicia, Santiago de Compostela Cathedral, 12th century, 19th century

Alli vamos a colocarnos. No haremos un retrato; esculpiremos un símbolo. Será un artista cualquiera y no el maestro Mateo el que contemplará desde el pórtico de la Gloria al apóstol Santiago sentado en el tabernáculo de la capilla mayor. ¡ De espaldas a los vicios!... Asi debe caminar el hombre por el mundo. iY de rodillas! De esta manera devuelve el artista a Dios la chispa de luz celestial que ha depositado en su cabeza. (Antonio Neira de Mosquera, Historia de una cabeza, 1850)

\section{El Salvador, la Gloria y la Nueva Jerusa- lén}

Aunque son muy numerosos los autores que han tratado de analizar las múltiples representaciones sacras que se dan cita en ese gran drama humano y divino que es el Pórtico de la Gloria - con razón López Ferreiro lo consideró "un compendio de la Historia de la Humanidad"2-, suele aceptarse que todas ellas, con sus diferentes lecturas, quedan subordinadas a la visión gloriosa 


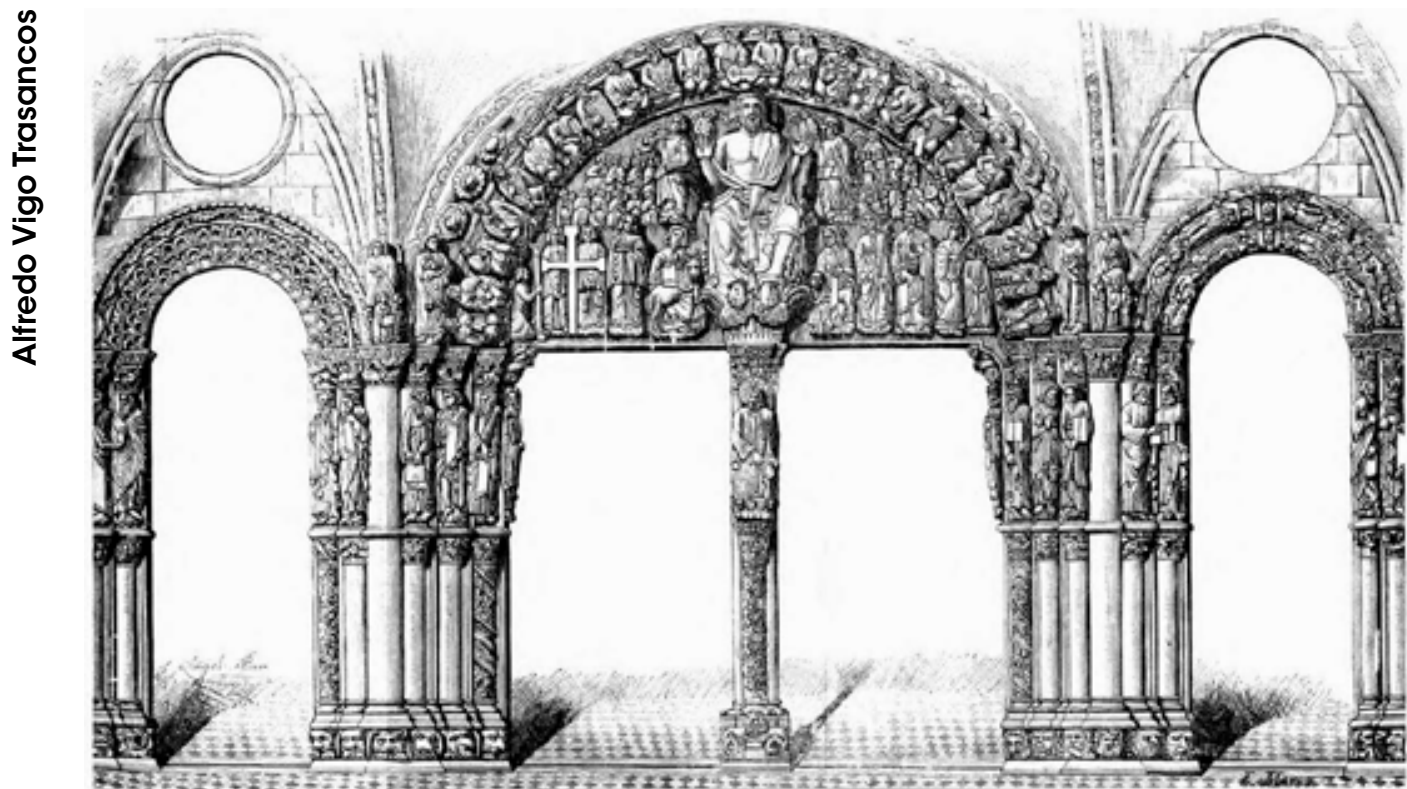

Fig. 1. Pórtico de la Gloria, dibujo de E. Mayer grabado por A. Bar (Foto: A. López Ferreiro, El Pórtico de la Gloria, 1893)

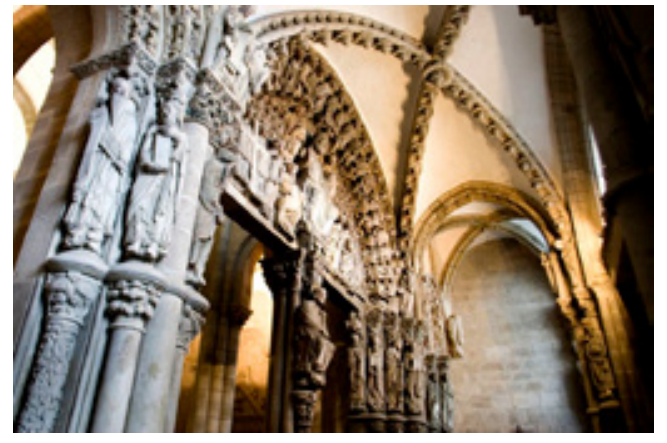

Fig. 2. Sector principal del Pórtico de la Gloria con sus abovedamientos (Foto: www.caminodesantiago.gal)

de Jesucristo que, como Rey y Salvador, se aparece sedente y coronado en el centro del gran tímpano, dominando con su presencia la visión apocalíptica de la Nueva Jerusalén hacia la que son conducidos los justos del pueblo judío y los bienaventurados del resto de las naciones tras haber superado el filtro dramático del Juicio Final ${ }^{3}$. La propia arquitectura del Pórtico pone énfasis en esta cuestión de "territorios" narrativos - recuérdese que a la izquierda se representa el limbo, los justos y los profetas del Antiguo Testamento, a la derecha los apóstoles y el juicio final-infierno y en el centro la genealogía de Cristo y su visión gloriosa en la Ciudad de Dios -, pues dos altísimas columnas de porte monumental separan los tres arcos y es distinta igualmente la propia decoración de sus bóvedas (fig. 1). De hecho, son sencillas, iguales y surcadas por simples nervios apenas decorados las de los tramos colaterales y, en cambio, adornada con flores y gruesos y extraños frutos la del tramo principal - la Gloria en la Ciudad de Dios - que ha de tener, sin duda, una clara significación metafórica (fig. 2). Difícilmente podrán interpretarse tales formas claramente vegetales como un trasunto de cualquier elemento de tipo astral - sol, luna o estrellas ${ }^{4}$ - pues, como sabemos por el Apocalipsis de San Juan, en el Cielo Nuevo de Dios, en donde está la Ciudad Santa, no hay noche, ni tampoco sol ni luna "porque la ilumina la gloria de Dios y su única lámpara es el Cordero"5. Es decir, que se busca separar el cielo terreno del otro cielo superior, evocando la Jerusalén Celeste como ya en su día señaló Moralejo y que puso de manifiesto al recordarnos que en la cripta del Pórtico - metáfora del mundo terrenal - estaban el sol y la luna en las claves de sus bóvedas y, por el contrario, en la zona alta de la tribuna del Pórtico, la representación del Cordero entendido así como su única y suprema lumbrera ${ }^{6}$. 


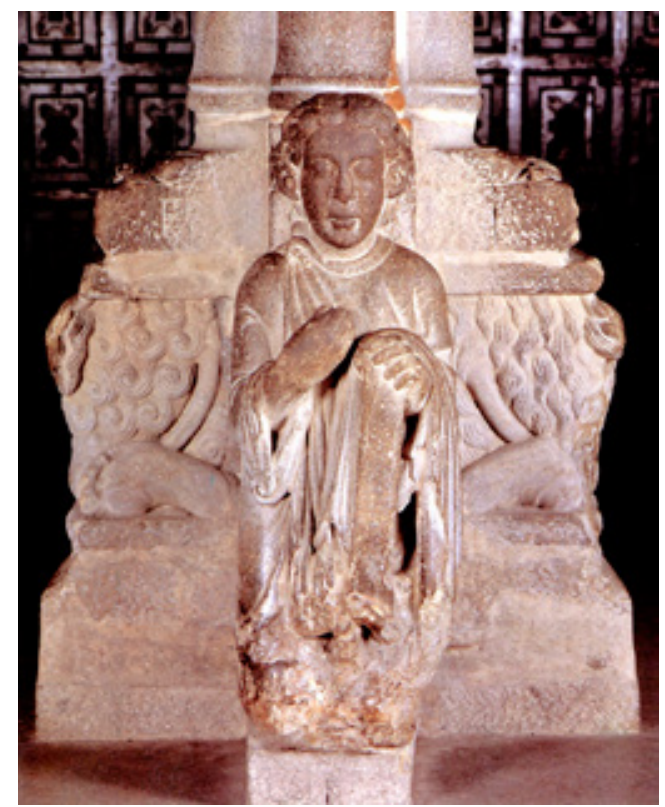

Fig. 3. Joven penitente de la parte posterior del parteluz del Pórtico de la Gloria popularmente conocido como "Santo dos Croques" (Foto: www.epapontevedra.com)

Dicho esto, tampoco está de más recordar que, según el Apocalipsis, en la Ciudad Santa de Dios, se encontraba el "árbol de la vida" de cuyos abundantes e inagotables frutos se alimentaban los bienaventurados que, gracias a ellos, gozaban, sin sufrir ningún dolor, de la vida eterna?

Quizá por esta razón se explique la presencia, en la bóveda central, de formas vegetales de las que surgen frutos que, de este modo, parecen sugerir la presencia de una exuberante y alimenticia pérgola que evocaría en el Cielo de Dios la imagen primigenia del más extraordinario y celestial Edén ${ }^{8}$. Es decir, más o menos, lo que se aprecia también en la puerta occidental de la iglesia de San Juan de Portomarín, muy mateana, en donde, en efecto, junto a la visión sintética de la Gloria apocalíptica, también se ven en las arquivoltas formas vegetales y una arquería decorada con jugosos frutos`. Más aún, el saber que en el "Nuevo Cielo" y la "Nueva Tierra" de Dios sería Cristo quien, como Salvador, reinaría para siempre ante la gozosa contemplación de su pueblo de elegidos - los bienaventurados de todas las naciones y pueblos -, nos hace evocar la figura del Salvador como "el Alfa y la Ome- ga" o el principio y el fin ${ }^{10}$, toda vez que, en la propia arquitectura de la catedral de Santiago, al oriente se inicia el templo jacobeo románico con la vieja capilla dedicada al Salvador y se culmina al occidente con el Salvador del Pórtico esta vez integrado en el tema apocalíptico.

No carece de sentido esta doble alusión salvífica de Jesucristo; pero además debe recordarse que estamos en la casa del apóstol Santiago, que San Juan era su hermano, el propio Juan el autor del Apocalipsis, y eso explica que, en la escultura que lo representa, en el pilar de la derecha y junto a Santiago, lleve Juan un libro en el que va escrita una famosa frase de su visión: "Vi la ciudad santa, Jerusalén, que descendía del cielo enviada por Dios" "1. Sin duda una alusión a lo que vemos dominando la zona alta y central del Pórtico que, a su vez, estaría coronada por la tribuna, obviamente la parte más elevada del mundo celestial que coronaría la Gloria y estaría iluminada por la imagen luminosa del Cordero; de ahí su vertiginosa altura y sus enormes horadaciones que hacen suponer un mundo superior sublime, ascendente, inmaterial y lleno de luz.

\section{El supuesto autorretrato del Maestro Mateo, el "Santo dos Croques" y la palabra ARCHITECTUS}

Ahora bien, junto a todo esto que parece muy preciso, en otras zonas del pórtico hay muchas otras historias, representaciones y personajes que han despertado muy distintas interpretaciones. Esto se explica porque muchas de las figuras llevan cartelas con textos escritos que ayudaban a identificarlas y que hoy se han borrado en su gran mayoría. Ayudaban a sonorizar el silencio, tal como dijo en su día el canónigo compostelano José María Díaz ${ }^{12}$. Su pérdida complica sobremanera identidades y significados pues, de existir, seguramente simplificarían muchas interpretaciones que se han vertido ${ }^{13}$.

No es cuestión aquí de resolver esta espinosa cuestión que da, sin duda, para muchas lecturas e investigaciones; pero con el fin de aclarar algún aspecto referido a ellas, sí me parece de interés que nos centremos en analizar el curioso caso de una palabra que, tradicionalmente, siempre se ha puesto en relación con la figura arrodillada que, tras el parteluz central, mira hacia el altar 


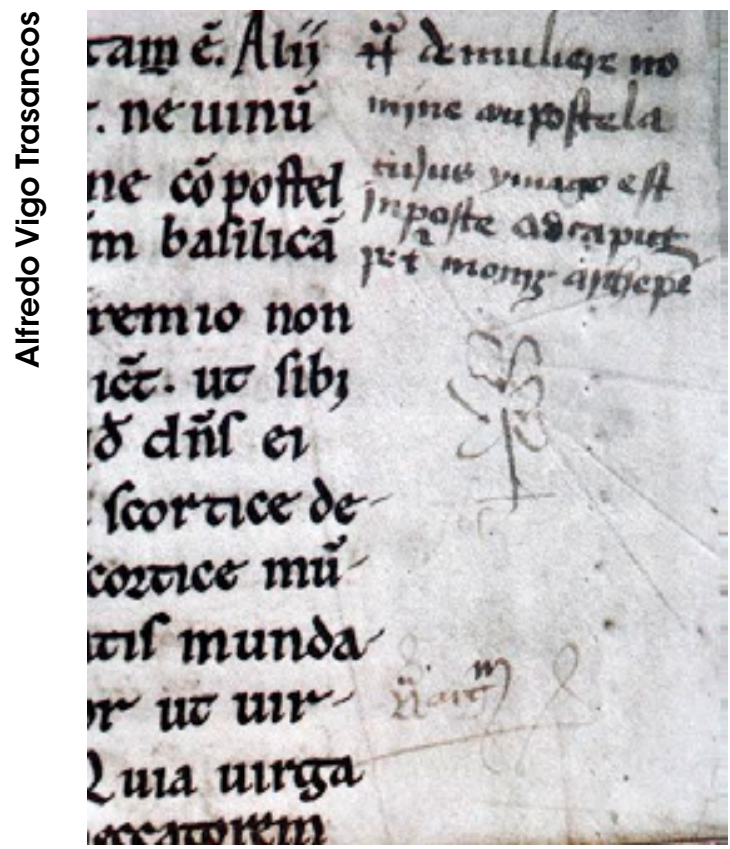

Fig. 4. De muliere nomine Compostela..., Códice Calixtino, libro I, cap. XVII, fol. 765. Nota marginal (Foto: O Pórtico da Gloria e o seu tempo, 1988)

mayor, se la conoce con el nombre popular de "Santo dos Croques" o "Santa" o "Santiña da Memoria" y ha solido identificarse con el autorretrato del Maestro Mateo, autor del Pórtico, basándose precisamente en el hecho de que llevaba en la cartela que sostiene su mano izquierda un vocablo, hoy desaparecido, que ponía en letras capitales: "ARCHITECTUS" (fig. 3).

Debe afirmarse que tal suposición, al igual que la que quiere ver en la figura del arrodillado la imagen genérica de un artista o arquitecto, ha de considerarse una falsedad histórica que no va más allá del siglo XIX, aunque sea cierto que, desde entonces, a pesar de algunas críticas, sigue resistiéndose a morir. De hecho, en toda la bibliografía histórica que hemos consultado anterior a ese siglo, además de la escasa atención que se le presta a las figuras y temática del Pórtico ${ }^{14}$, puede decirse que no hay ninguna referencia al joven arrodillado del parteluz más allá de una breve nota puesta al margen del ejemplar del Codex Calixtinus de la catedral (fol. Lxxvj, Lib. I, cap. XVII) que la identifica con una mujer de nombre "Compostela" que, dice la glosa, "est in poste ad

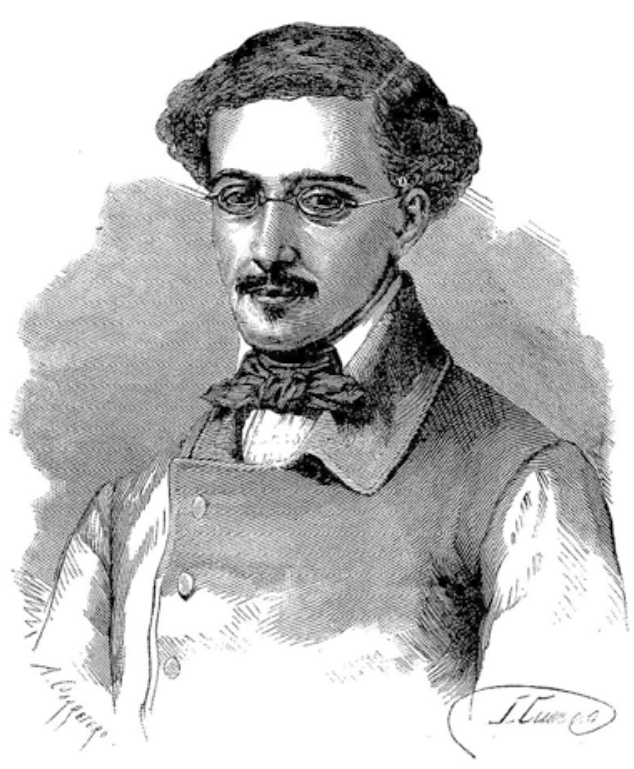

Fig. 5. Retrato de Antonio Neira de Mosquera en La llustración Gallega y Asturiana (11 de marzo de 1880), por José Fernández Cuevas, según grabado de Carretero (Foto:https:// es.wikipedia.org)

caput Petri moniz archiepiscopi"15 (fig. 4); es decir, que estaba muy cerca del desaparecido sepulcro primitivo del arzobispo Pedro Muñizi ${ }^{16}$ que hoy ha sido sustituido por una lápida de bronce mucho más moderna ${ }^{17}$. Cuenta Moralejo que esta nota debió de ponerse hacia 1400, lo que pone de manifiesto que, ya para entonces, la figura del joven arrodillado era ya controvertida ${ }^{18}$, pues se la identifica con una imposible imagen de mujer que, además, llevaba el nombre de la ciudad del Apóstol19. Ninguna mención a Mateo, al "Santo dos Croques", a la "Santa" o "Santiña da Memoria" por la que es popularmente conocida y, por supuesto, sin aludir tampoco a la palabra escrita en la citada cartela.

En los siglos posteriores los resultados son todavía más silentes, pues ni Andrade, Mendoza de los Ríos, Riobóo, Miguel Ferro Caaveiro, ni tan siquiera Ceán Bermúdez mencionan al citado orante, ni tampoco la palabra ARCHITECTUS que, de haber existido, es seguro que habría despertado el interés de tan destacados personajes de la historia de nuestra arquitectura y de la catedral de Santiago. No olvidemos que Domingo de Andrade fue el arquitecto compostelano más 


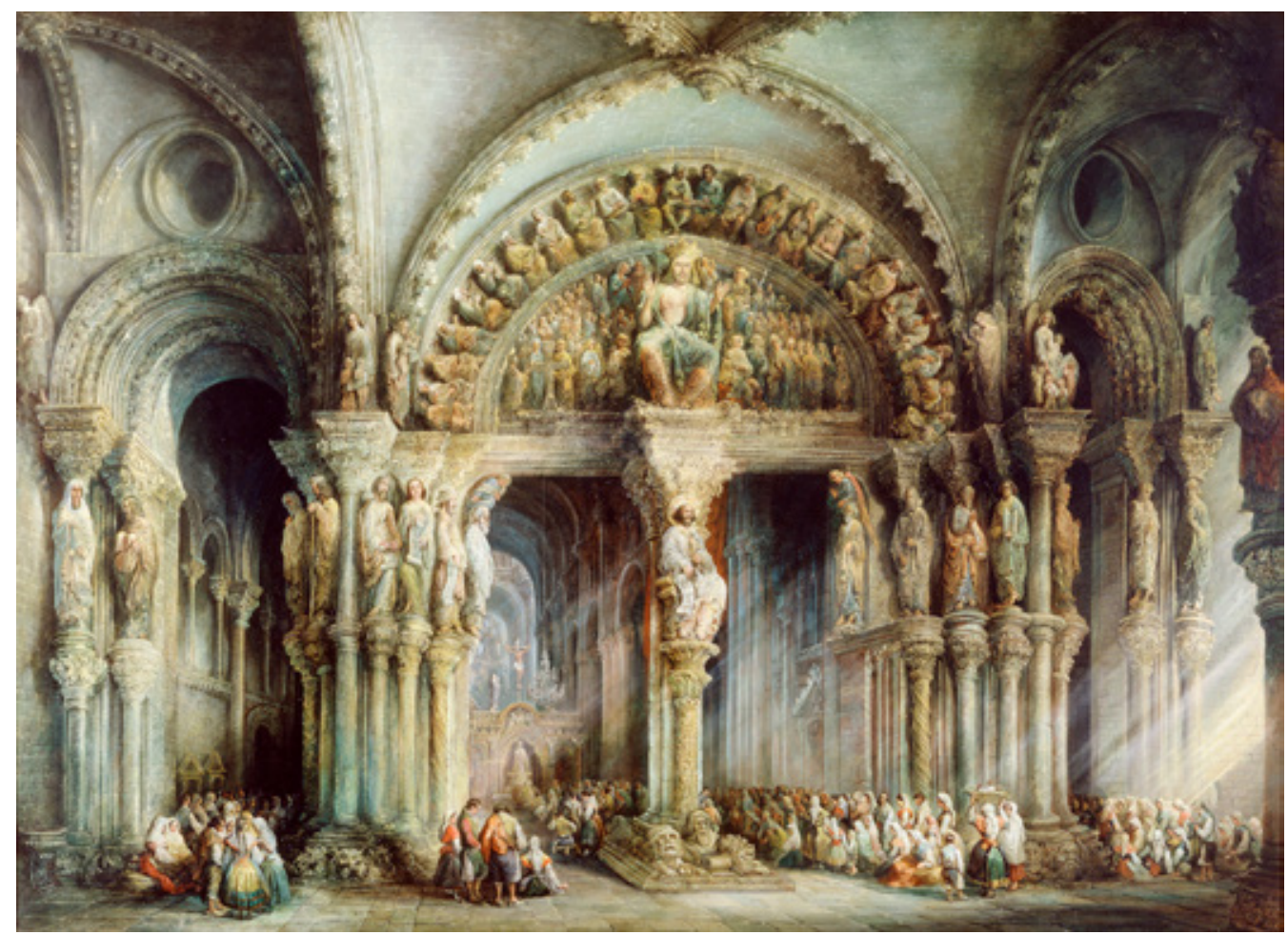

Fig. 6. Pórtico de la Gloria, por Jenaro Pérez Villaamil, 1849-1850. Patrimonio Nacional, Palacio de la Moncloa. Núm. catálogo: PI-19E1431P, núm. inventario: 10055399

interesado en reivindicar la importancia de la arquitectura y el papel de su profesión y que una mención así, tan erudita y precisa, hubiera dado alas a sus reivindicaciones que expresó con contundencia en su obra titulada Excelencias, antigüedad y nobleza de la Arquitectura que publicó en Santiago en $1695^{20}$. Tampoco mencionan ni la figura ni la palabra en cuestión ni Mendoza de los Ríos -1731-21, ni Riobóo y Seixas -1747- a pesar de interesarse el primero en valorar las "maravillas" arquitectónicas del templo jacobeo y ser el segundo uno de sus primeros historiadores ${ }^{22}$. Asimismo, Miguel Ferro Caaveiro, hijo de arquitecto y él mismo maestro de obras de la catedral en el período ilustrado, tan preocupado por este tipo de cuestiones, tampoco señala al orante y su mención de profesión, a pesar de que, en una colección de planos de gran rigor que ejecutó en 1794 de la catedral compostelana, señala el nártex compostelano como "Magnífico pórtico i principal entrada de esta Sta. Yglesia, echo en tiempo de Dn. Fernando $2^{\circ}$ y del Eminentíssimo
Señor Arzobispo don Pedro Suárez de Deza; cuya obra se ha concluido en 1188 , según se lee en la inscripción esculpida en los dinteles de las Puertas" 23. Finalmente, tampoco Ceán, que en 1800 menciona a Mateo en su Diccionario histórico de los más ilustres profesores de las bellas artes en España, nada dice referido a la escultura y a la palabra Architectus ya a las puertas del siglo XIX ${ }^{24}$, del mismo modo que silencian también tales datos Eugenio Llaguno en 182925, Inclán Valdés en $1833^{26}$, Richard Ford en la primera edición de su A Handbook for Travellers in Spain -1845-27, los autores anónimos del Manual del viajero en la catedral de Santiago de 184728, José Caveda y William Stirling-Maxwell en $1848^{29}$ o la publicación de Francisco de Paula Mellado que alude al Pórtico justamente en $1850^{30}$. Por lo tanto, todo parece indicar que la "falsedad histórica" sobre el autorretrato del maestro y su famoso vocablo debieron surgir justo a partir de esta fecha. 
Fueron Matilde Mateo $^{31}$ y Serafín Moralejo 32 , en efecto, los primeros en atribuir a una narración del escritor compostelano Neira de Mosquera la identificación de una figura del Pórtico con un autorretrato del Maestro Mateo, pues así lo indica este autor en Historia de una cabeza que publicó en $1850^{33}$ (fig. 5), para rendir homenaje a su amigo el pintor Jenaro Pérez Villaamil que, poco antes, había procedido a dibujar y pintar el Pórtico de la Gloria ${ }^{34}$ en un gran lienzo que hoy se encuentra en el Palacio de la Moncloa35 (fig. 6). Como el cuadro del pintor romántico ferrolano, que no carece de imaginación, también el relato de Neira es igualmente fantasioso, pues aunque toma la historia como trasfondo, no deja de subordinarla a la narración novelada que él nos quiere transmitir, llena de licencias históricas como ya en su momento destacó Julio Vázquez Castro al analizar su figura como "historiador" y su "estudio" sobre el gran Botafumeiro compostelano ${ }^{36}$. No es, pues, su texto, un trabajo de investigación histórica convencional; todo lo contrario, se trata de un relato histórico-novelesco que participa de todo tipo de fantasías. $Y$ entre ellas cuenta el escritor que el Maestro Mateo, arquitecto de palacio del rey Fernando II, orgulloso de su gran realización en el Pórtico de la Gloria, se había atrevido a autorretratarse en la figura del joven arrodillado que aparece en el ángulo izquierdo del gran tímpano compostelano llevando en sus manos una columna - en realidad se trata de un ángel con uno de los símbolos de la pasión de Cristo o "Arma Christi" -, que él interpreta como un claro elemento de su profesión de arquitecto ${ }^{37}$. Sigue luego indicando Neira que el día de la inauguración oficial del Pórtico - 1188 - toda la multitud que lo contemplaba se dio cuenta de este hecho, por lo que, indignado el arzobispo Pedro Suárez de Deza de que Mateo se hubiese atrevido a retratarse en la Gloria y entre los bienaventurados, lo reprendió, obligándole a hacer desaparecer su cabeza de la figura si es que no quería ser excomulgado. Así lo hizo Mateo; eliminó su retrato de la cabeza del joven y la sustituyó por otra que representaría a Sansón; aunque disconforme con esta desaparición de su cabeza, a la vista del Pórtico discurrió situar una figura que lo volviese a evocar - así lo indica claramente en el texto que hemos elegido para abrir este artículo - a espaldas del parteluz, mirando al

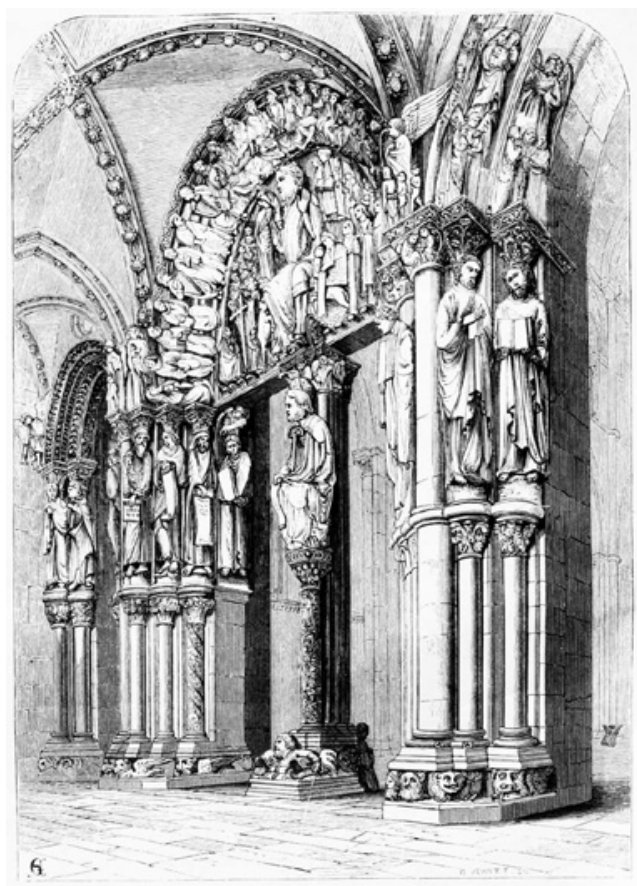

Fig. 7. Pórtico de la Gloria, por O. Jewitt (Foto: Some Account of Gothic Architecture in Spain, de George Edmund Street, 1865)

altar, aunque, precisa el autor, no sería un autorretrato, sino un símbolo; es decir, que la nueva figura representaría "un artista cualquiera y no el Maestro Mateo" que contemplaría desde el Pórtico al apóstol Santiago sentado en el tabernáculo, y de rodillas, para que de esta manera devuelva "el artista a Dios la chispa de luz celestial que ha depositado en su cabeza" ${ }^{38}$. Esto sería lo que justificaría que la muchedumbre tomase la efigie del arquitecto por un voto del religioso Maestro Mateo, por lo que, dice Neira, "de siglo en siglo ha llegado hasta nosotros la tradición de que esta imagen representa el ingenio tributando respeto y admiración al poder divino", de lo que resultó que la imagen fuese conocida como "Santo de las cabezadas" o, lo que es lo mismo, "Santo dos Croques" ${ }^{39}$.

No fue más que el principio. Puesta la simiente, era cuestión de tiempo que fuesen brotando nuevas y ampliadas interpretaciones. Sólo diez años después, de hecho, en 1860, Rada y Delgado vuelve a insistir, ya como si fuera una auténtica verdad histórica, en todo lo indicado por Neira, 


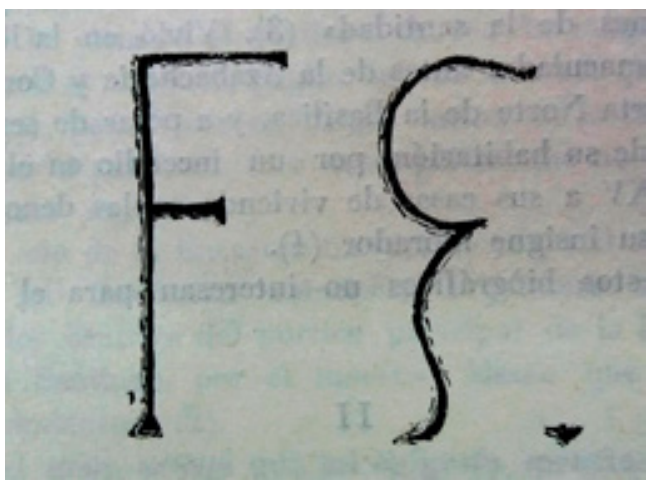

Fig. 8. Inscripción en la base del parteluz del Pórtico de la Gloria inmediata al "Santo dos Croques", según calco de Fermín Bouza Brey (Foto: Compostellanum, 1959)

aunque añadiendo esta vez de su cosecha que el arquitecto había puesto "su estatua en el pavimento de la catedral, en el confín de la que hoy se llama la nave de la Soledad" dando pie a que se identificase al "orante" con nuestro arquitecto e insistiendo de nuevo en la tradición popular del "Santo dos Croques" 40 . Sólo un año más tarde, la "leyenda" de Mateo volvió a acrecentarse al señalar Antonio de la Iglesia, en 1861, que Mateo se había retratado "postrado en tierra contrito y limpio ya de pecado", con "su rostro algo largo y joven todavía, su cabeza de pelo ensortijado en mechones", con su mano derecha golpeando el pecho, y en su izquierda "el título de su profesión: Ahí tenéis al grande artista Matheo" ${ }^{41}$. Ni que decir tiene que era el paso previo a ver ya una palabra concreta escrita en la cartela que llevaba en la mano el personaje, si bien nada dice de ella ni de la personalidad del orante George Edmund Street, el famoso historiador y arquitecto historicista británico, que visitó Santiago en $1863^{42}$ y publicó los datos referidos a la catedral y el Pórtico en 1865; algo ciertamente sospechoso ${ }^{43}$ (fig. 7). En cambio, en 1866, un historiador del prestigio de Villaamil y Castro, crítico por cierto con la narración de Neira al que tacha de tener "una imaginación algo exaltada" y ser artífice de "caprichosas creaciones" 44 , cae en la tentación y cita, por primera vez de manera muy explícita, que la estatua de Mateo llevaba escrita en su cartela la palabra ARCHITECTUS45; esto a pesar de ser él el primer historiador de prestigio que abordó la historia y la descripción de la catedral de Santiago. No desmintió su afirmación otro peso pesado de la historiografía compostelana del momento como fue Antonio Zepedano y Carnero, prestigioso canónigo de la catedral, que en 1870 volvió a decir que la estatua arrodillada de Mateo llevaba escrita la palabra Architectus convirtiendo esta afirmación en una verdad incontestable ${ }^{46}$, lo que volverá a repetir, ese mismo año, Bernardo Fernández en su Reseña Histórica del Pórtico de la Gloria ${ }^{47}$.

La razón de por qué se extendió esta falsedad histórica entre tan destacados historiadores, no la llegamos a comprender más allá de que resulta muy atractiva en una época que sintió especial interés por el arte medieval y las biografías de los grandes artistas convertidos muchas veces en auténticas leyendas ${ }^{48}$; pero lo cierto es que, a partir de entonces, otros autores volvieron a insistir en que el orante era el retrato de Mateo y que, en efecto, éste llevaba en su mano la cartela con la ya citada escritura, como confirman las informaciones que nos proporcionan personalidades como el británico Lonsdale ${ }^{49}$, el español Álvarez de la Braña ${ }^{50}$ o el ya citado Richard Ford que, por cierto, en la quinta edición de su famoso Handbook, publicada en 1878, sí daba cuenta de las últimas argumentaciones referidas al famoso "orante" y a la palabra Architectus ${ }^{51}$.

Sea como fuere, a partir de la década de 1880, a la vez que se sigue insistiendo en que el orante es un retrato de Mateo que daba forma al "Santo dos Croques" 52, también se empieza a poner en entredicho que tuviese en la mano la mencionada palabra. Fernández Sánchez y Freire Barreiro fueron, de hecho, los primeros en indicar, en 1880, que la estatua orante del Pórtico llevaba en la mano izquierda un rollo "donde se leía en otro tiempo la palabra ARCHITECTUS", por lo que no olvidan mencionar que, para entonces, estaba ya "enteramente borrada"53; lo mismo señala el gran historiador de la catedral Antonio López Ferreiro en 1886 al afirmar que la representación de Mateo, "según algunos" Ilevaba "escrita antiguamente" la palabra ARCHITECTUS, dejando claro que en ese momento nada se podía leer ${ }^{54}$. Por el contrario, es el primero en indicar que, tras la figura del orante y en el pedestal del parteluz, sí existía una inscripción en la que nadie había reparado y en la que parecía leerse, según él, FEC; es decir FEC(IT) (hizo) ${ }^{55}$, con lo que, a falta 
de una certeza para la primera palabra desaparecida, la nueva inscripción así leída reforzaba la identificación del arrodillado con la supuesta figura del Maestro Mateo56 (fig. 8). Podríamos seguir citando a otros autores que repiten con más o menos fidelidad datos y atribuciones en las que no queremos insistir y que en ocasiones, tratando de incrementar la leyenda, ponen en relación al penitente con el yacente de bronce que presidiría la tumba desaparecida del arzobispo Pedro Muñiz, muerto en $1224^{57}$. Por eso que sea muy importante volver de nuevo sobre la figura del ya mencionado Villaamil y Castro, aunque solo sea por haber cuestionado en una nueva publicación que existiese en la cartela la palabra ARCHITECTUS. Recuérdese que la había mencionado por primera vez y sin titubear en 1866; ahora en cambio, en 1909, cuarenta y tres años después, consciente seguramente del error que había cometido, se limita a decir que en el citado tarjetón "antiguamente, según algunos, estaba escrito ARCHITECTUS"58; una manera, pues, de corregirse de un modo preciso, aunque discreto. Esta vez cita también las letras FEC del pedestal interpretándolas como FEC(IT) ${ }^{59}$, al igual que López Ferreiro. En suma, que todo lo que hemos expuesto parece indicar que cualquier identificación del orante con Mateo, con la representación genérica de un arquitecto, con el "Santo dos Croques" o "Santiña da Memoria" o con la supuesta certeza de que llevaba en la mano la cartela con la citada palabra alusiva a su profesión, no parece en absoluto que se pueda retrotraer más allá de 1850, 1861 o 1866 respectivamente, coincidiendo justamente con el auge del romanticismo y con el rebrotar del historicismo medieval que quiso poner en valor toda la artisticidad del Pórtico de la Gloria; y justo en el tiempo en que lo pintaba Jenaro Pérez Villaamil, lo fotografiaba Charles Thurston Thompson ${ }^{60}$, lo rescataban del silencio tantos cultos eruditos y alcanzaba la fama inmortal a través del vaciado que, por ese tiempo, se expuso en una de las salas del South Kensington Museum de Londres tal como ha estudiado con precisión Matilde Mateo ${ }^{61}$.

Por otra parte, la palabra ARCHITECTUS, tan antigua y vitruviana, se integra mal en un contexto medieval del siglo XII como el que comentamos ${ }^{62}$. No era habitual, y menos en España, denominar en la Edad Media "architectus" 63 a los responsables de diseñar o llevar a cabo una obra arquitectónica ${ }^{64}$. Lo habitual era denominarlos, según nos recuerda Beatriz Mariño, como "caementarius" o "latomus", o mejor aún "magister", si bien este término se empleaba indistintamente para referirse tanto al arquitecto, como al escultor o al clérigo encargado de la supervisión ${ }^{65}$. Para mayor confusión, señala la autora, que fórmulas como la de "sapiens architectus", que aparecen con frecuencia en los documentos medievales, no se refieren al arquitecto, sino al comitente, al que se parangona con el «sabio arquitecto» de la Carta de San Pablo a los Corintios ${ }^{66}$.

En todo caso, cuenta Macdonald que en época romana era común que todos los técnicos dedicados a la construcción se autoproclamasen "architectus", como se aprecia en las numerosas lápidas funerarias que se pusieron en las tumbas de tantos artífices que se dedicaron a esta actividad67, pero con el tiempo, en la Edad Media, el término cayó en desuso, precisamente, dice Kostof, porque el concepto clásico de arquitecto representado por Vitruvio fue sustituido por otro: el arquitecto como maestro constructor que, tomando sus títulos del mundo de las agrupaciones masónicas ${ }^{68}$, prefirió asumir los términos ya comentados; también aparece el de "didascalus lapicida" tal como refiere el Codex Calixtinus ${ }^{69}$. Con todo, se prefirió el de "magister" pues así menciona el Calixtino al primer arquitecto responsable de la catedral de Santiago - "domnus Bernardus senex, mirabilis magister"70-, así nombra también Fernando II al Maestro Mateo en el documento de 1168 que lo vincula de por vida a las obras de la catedral - "magistro Matheo"71 - y así se denomina a sí mismo el propio Mateo en la famosa inscripción de los dinteles del Pórtico de la Gloria que fue colocada donde hoy la vemos en 1188: "Magistrum Matheum"72. Debe precisarse, no obstante, tal como señala Vázquez Castro, que el término indicado solo se justifica cuando el lapicida, el cantero o el "pedreiro" tiene a su cargo la maestría de una obra o construcción"73, como es el caso de los "maestros" que hemos señalado. Por lo tanto, nada tiene de extraño que, en referencia a Galicia, en la tardía Edad Media siga denominándose a los principales constructores o arquitectos que llevan la dirección de una fábrica, "maestro de la obra" - sin duda derivado 


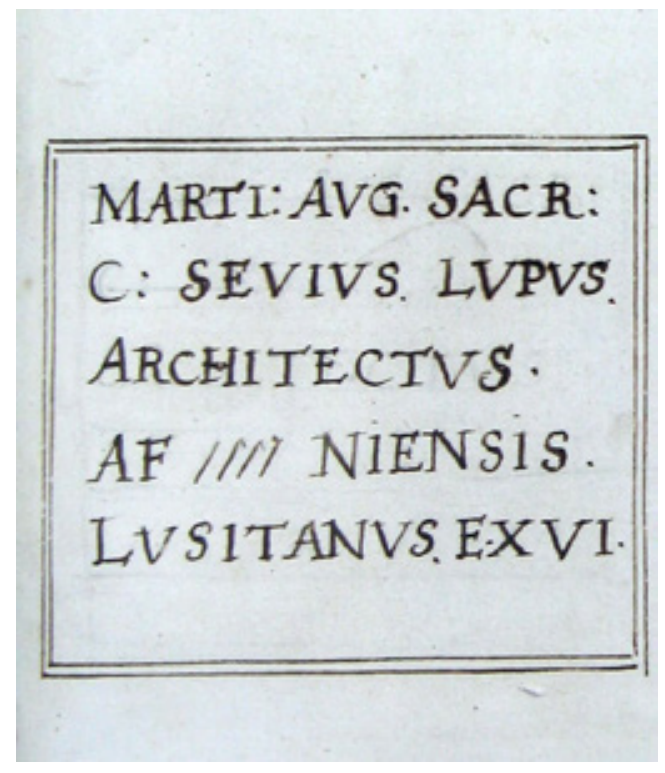

Fig. 9. Inscripción romana de la Torre de Hércules de A Coruña transcrita por el canónigo cardenal de la catedral de Santiago Jerónimo del Hoyo hacia 1607. Archivo Histórico Diocesano de Santiago, Fondo General, serie: Visita pastoral (1.52), $\mathrm{n}^{\circ}$. 1 (detalle)

de "magister operis" - o "maestre/mestre/meestre da obra", tal como ponen de manifiesto buen número de documentos referidos al período ${ }^{74}$.

Al mismo tiempo, la figura juvenil del supuesto autorretrato del artista ${ }^{75}$ tampoco lleva ningún atributo que permita identificarlo con un arquitecto o constructor, pese a que, en la Edad Media, ya era habitual identificar el cargo del maestro de obras con una autoridad que solía llevar en la mano una vara de medir o cualquier otro instrumento - bastón de mando, compás o escuadra - característico de la profesión ${ }^{76}$. Por lo tanto, sin elemento alguno que ayude a identificarlo y sabiendo ya que la palabra ARCHITECTUS ha de verse como una invención decimonónica seguramente cargada de intenciones y no pequeña erudición - uno de los pocos arquitectos gallegos que se atrevió a proclamarse como tal en una inscripción pública fue Clemente Sarela en 1758 al disponerla en la fachada principal de la barroca Casa del Cabildo de Santiago de Compostela: "ARCHITECTO SARELA" 77 -, no es imposible que quisiese ser un eco en Compostela, de la inscripción romana - siglo I - que, en efecto, tenía la Torre de Hércules de A Coruña y que proclamaba

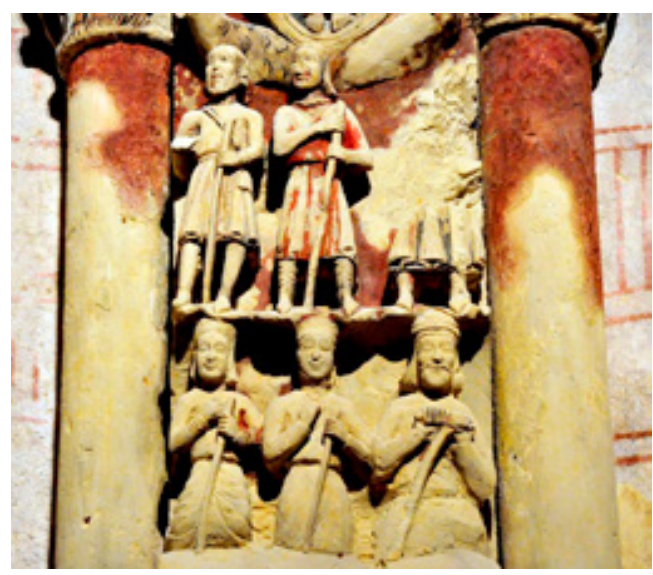

Fig. 10. Representación de seis peregrinos en distinta actitud y de diferente clase social esculpidos en la iglesia de Santiago de Turégano (Segovia), de principios del siglo XIII (Foto: https:// www.flickr.com)

al mundo a quién estaba dedicado el viejo Faro romano de Brigantium, quién había sido su autor y qué profesión había ejercido:

$$
\begin{gathered}
\text { MARTI } \\
\text { AVG.SACR } \\
\text { C.SEVIVS } \\
\text { LVPVS } \\
\text { ARCHITECTVS } \\
\text { AEMINIENSIS } \\
\text { LVSITANVS. EX.VO }{ }^{78} \text { (fig. 9) }
\end{gathered}
$$

Y no olvidemos que esta inscripción era, para entonces, sobradamente conocida por todos los eruditos $^{79}$, por lo que no sería extraño que sirviese de inspiración a quien propuso evocarla ficticiamente en la cartela del pseudo-Mateo, sin duda para engrandecer su fama, su leyenda y la de su formidable portal.

Descartado que la figura arrodillada del Pórtico haga alusión a Mateoso, a cualquier arquitecto $^{81} \mathrm{o}$ artista en general y también que llevase en su día la palabra señalada, todo parece indicar que el personaje que hoy conocemos como "Santo dos Croques", debió de tener otra identidad fácil de reconocer en su día gracias al auténtico vocablo que llevaría en su cartela y que hace siglos desapareció. No es la primera vez que algún autor ha dudado de los planteamientos tradicionales proponiendo para la figura otras identidades. Aunque sin ponerlo en relación con ningún personaje en concreto, Michael L. Ward 


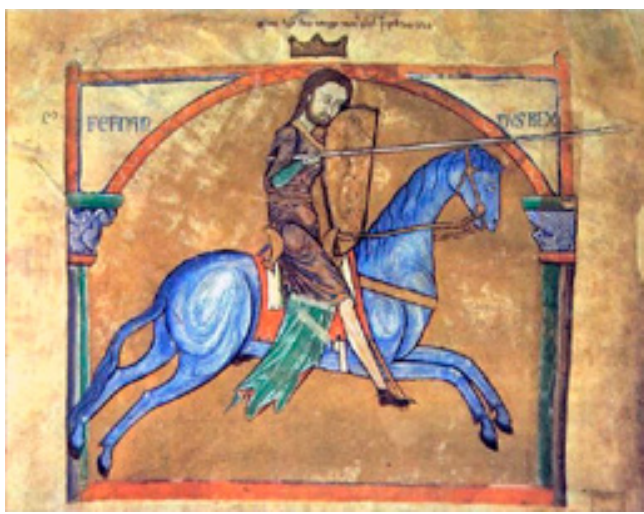

Fig. 11. Imagen ecuestre del rey Fernando II. Miniatura del Tumbo A de la catedral de Santiago de Compostela. (Foto: https://www.wikimedia.org)

pone en duda la atribución tradicional y señala claramente que su identificación con Mateo no era, en absoluto, satisfactoria ${ }^{82}$. Más preciso Manuel Núñez, la ha identificado con "Meus peregrinus" o, lo que es lo mismo, con la imagen del peregrino devoto y arrepentido que se acercaría al santuario jacobeo en actitud penitente ${ }^{83}$, lo que tiene, en efecto, bastante sentido teniendo en cuenta la condición de centro de peregrinación que tenía el santuario jacobeo desde la Alta Edad Media. Sin embargo, es difícil de aceptar que un peregrino no lleve ningún atributo identificativo cuando, cuenta el Calixtino, todos los que venían a Compostela debían de llevar como elementos característicos el báculo y el morral benditos - con estos elementos se representan, en efecto, los seis peregrinos esculpidos en la iglesia de Santiago de Turégano (Segovia) a principios del siglo XIIIs4 (fig. 10) - que, en efecto, significaban el "hábito" de su peregrinación y "el sustento de la marcha y del trabajo" ${ }^{85}$. Ninguno de los dos elementos aparecen en el personaje arrodillado; tampoco se ve ninguna otra identificación reconocible - concha o venera, sombrero, manto corto, etc.; además, vestida como va la figura de una manera bastante clásica y elegante, más distinguida de lo habitual como confirma su manto afiblado, a manera de clámide, puesto sobre la túnica y anudado sobre el hombro derecho con aire ciertamente aristocrático ${ }^{86}$, parece que es también un dato que podría ir en contra de esta suposición pues los peregrinos suelen representarse con un atuendo más humilde, acorde

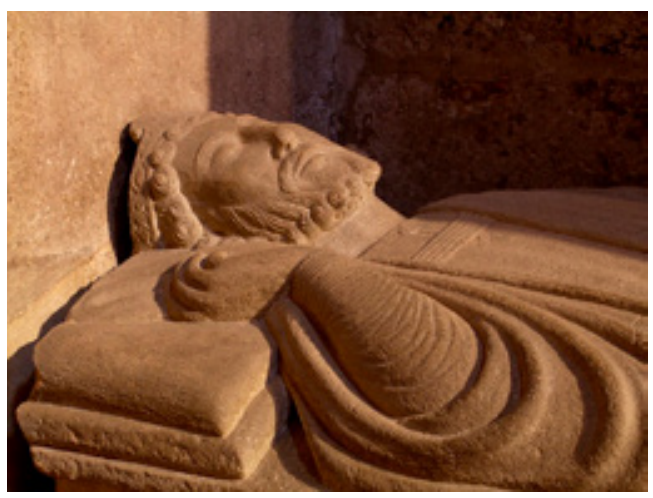

Fig. 12. Sepulcro del rey Fernando II o Alfonso IX, en la capilla de las Reliquias de la catedral de Santiago de Compostela (detalle). (Foto:http://3.bp.blogspot.com)

con su condición penitente y andariega. En otra dirección iconográfica, primero López Pacho $^{87}$ y más recientemente Claussen han sugerido que el pseudo Mateo arrodillado, por su vestimenta cortesana y claramente civil, podría ser una efigie del monarca Fernando II promotor del Pórtico, protector de Mateo y enterrado en la catedral en $1188^{88}$. Como sugiere este autor ${ }^{89}$ podría apoyar esta suposición la inscripción F o FE -vista al natural no está tan clara la lectura que propone López Ferreiro: FEC- que podría leerse en el pedestal y que aludiría a $F$ (ERNANDUS), descartando así el tradicional F(ECIT) que ya comentamos.

Con todo, tratándose del rey de León y de Galicia y de un personaje de tanta categoría que varias veces se autoproclamó "Hispaniarum Rex" ${ }^{\prime \prime}$, resulta extraño que no lleve ningún distintivo regio como sería, obviamente, la corona. También es atípico representar al "rey" en una imagen tan juvenil y lampiña cuando la "aetas" o edad de los personajes tiene en el Pórtico muy precisos significados, tal como en su día demostró Serafín Moralejo ${ }^{91}$. Por otra parte, no se debe olvidar que, al menos en la miniatura del Tumbo A, Fernando II aparece con barba, como queriendo dar a entender que estaba en la plenitud de su edad y madurez como monarca, asimismo representado como un activo y belicoso caballero - es una imagen ecuestre - y, por supuesto, como rey pues, aunque no lleva, como la gran mayoría de los monarcas que se representan en el Tumbo, la corona ceñida directamente a la cabeza, sí la lleva, en efecto, suspendida sobre ella92 (fig. 11). Es como si FERNANDUS REX fuese, en el Tumbo 


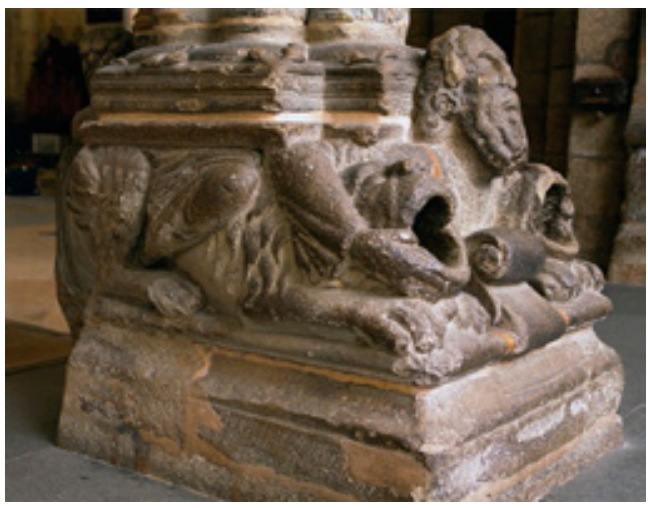

Fig. 13. Figura de hombre barbado agarrando por las bocas a dos leones en el basamento del parteluz del Pórtico de la Gloria (Foto: http://4.bp.blogspot.com)

A, el "alter ego" del Santiago ecuestre - lacobus miles Christi. También las representaciones numismáticas apuestan por un Fernando II barbado y con corona93 - suele llevar también un cetro crucífero y una espada -, lo mismo que las controvertidas figuras de los yacentes que presiden los sepulcros de Fernando II y Alfonso IX de la catedral de Santiago ${ }^{94}$ (fig. 12). Todo esto dificulta la identificación propuesta por Claussen, que debe ponerse, por tanto, en cuarentena.

\section{Hércules y España}

Dicho esto, la enigmática figura arrodillada que mira hacia oriente y al altar mayor, creo que debe ponerse en relación directa con la otra figura que también se encuentra en la base de parteluz pero, en este caso, mirando muy claramente hacia occidente. Es más, pienso que son complementarias, que están concebidas como el haz y el envés, si bien es seguro que han de ofrecer, a la vez, interpretaciones contrapuestas tal como parecen indicarlo sus propias posiciones encontradas, su distinta actitud y hasta su relación diferente con la misma arquitectura. El problema es que la nueva figura a la que nos referimos, y que lleva también una cartela con una leyenda bajo su pecho que ha desaparecido, es igualmente muy controvertida. Representa un personaje vigoroso, de rústica barba ${ }^{95}$, lleno de ímpetu vital que aparece, además, echado literalmente con su túnica y sus pies descalzos sobre dos poderosos leones que agarra con fuerza por sus fauces en clara expresión de dominio (fig.

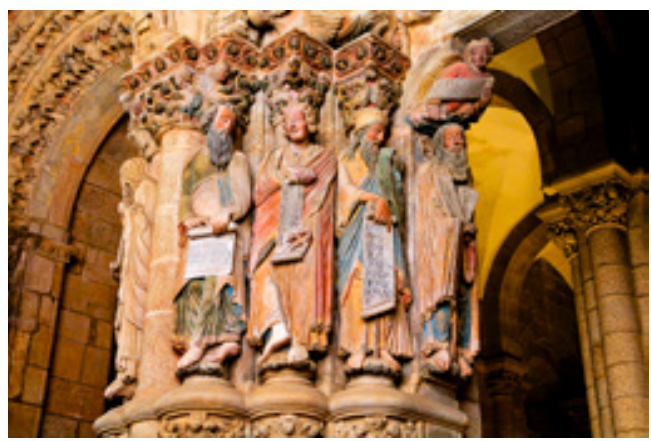

Fig. 14. Profetas de la jamba izquierda del Pórtico de la Gloria, con la figura juvenil y sonriente de Daniel. (Foto:http://www. nationalgeographic.com.es)

13). Junto a esto, no debemos olvidar que tan poderosa figura aparece asimismo aplastada con contundencia por el pilar del parteluz, de la misma manera en que lo están todos los animales, monstruos y hombres - también controvertidos en sus significados - que aparecen oprimidos en los basamentos por los restantes pilares del Pórtico. Visto así, todo lo que se encuentra debajo, aplastado y sometido por la arquitectura, parece querer subrayar la imagen simbólica del triunfo de la parte superior dominada por la Gloria. Por este motivo, sea cual sea la identidad del forzudo que nos ocupa - y de las restantes bestias, hombres y monstruos del basamento -, creo que debiera tener un claro significado negativo pues, aplastado como está, parece asociarse con aquel sobre el que se ha vencido. Así pues, identificarlo con Sansón, con Adán, con Daniel, con Gilgamés o incluso con Fernando II como alguna vez se ha propuesto, no me parece que sea correcto.

De ningún modo Gilgamés ${ }^{96}$ por lo extraño de su representación en la cultura medieval cristiana del siglo XII que no tiene, creo, justificación alguna y menos en un contexto religioso y jacobeo como es el compostelano; tampoco Adán"7 o Sansón ${ }^{98}$ porque, pese a haber tenido ambos sus flaquezas a los ojos de Dios, son personajes del Antiguo Testamento que siempre se vinculan con el mundo de los justos y que estarían, tras su muerte, en el Limbo de los patriarcas a la espera de su liberación por Jesucristo en su descenso a los infiernos ${ }^{99}$, tal como se ve en el arco de la izquierda. Además, el que aparezca la figura agarrando con sus manos dos leones, excluye la 


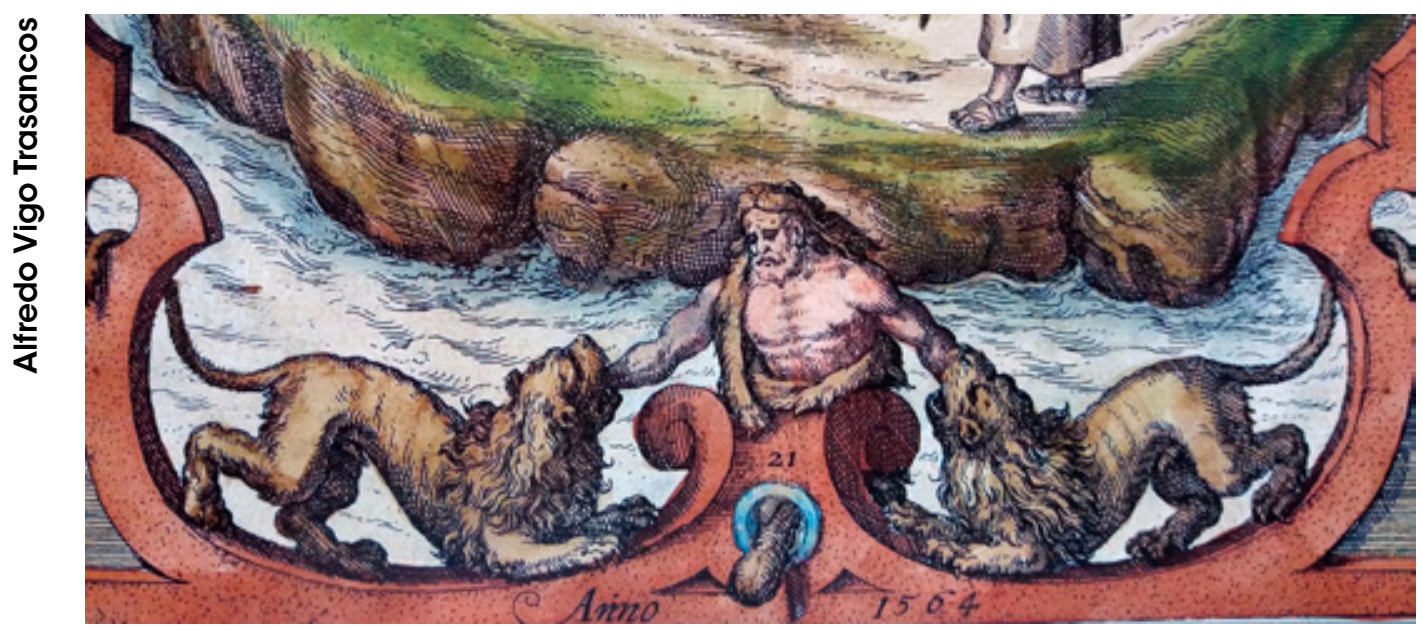

Fig. 15. Representación de las armas de la ciudad de Cádiz con Hércules dominando a dos leones. Gades Ab Occidvis Insvlae Partibvs. Año 1564. Depingebat Georg Hovfnaglivs. Civitates Orbis Terrarum

tradicional representación de ambos personajes bíblicos con un solo león como suele ser habitual; el primero por mostrarse así sólo cuando aparece como señor de los animales tras la creación ${ }^{100}$ y Sansón por su conocida lucha con el león en su famoso pasaje bíblico. Además éste último suele identificarse en el mundo cristiano, por su fortaleza, como una prefiguración del mismo Jesús ${ }^{101}$ que aquí, en la base del pórtico y aplastado, resultaría sorprendente ${ }^{102}$. Lo de Fernando II es, sencillamente, incomprensible, una licencia del historiador que la propuso que no aportó ningún argumento y que carece por completo de todo fundamento ${ }^{103}$; no tiene sentido que el rey que reina en Galicia y León, promueve el Pórtico, protege a Mateo y ayuda a engrandecer el templo apostólico aparezca, sin ningún atributo real, en una posición aplastada tan poco digna y comprensible y agarrando por las bocas dos leones. En cambio, Daniel en la fosa de los leones ha sido, hasta la fecha, la identificación que ha tenido mayor fortuna ${ }^{104}$; en parte por ser Daniel profeta y vidente que vio en sus sueños cuatro bestias muy semejantes a las que pululan por los basamentos. Pero a decir verdad, aunque a Daniel suele representárselo tanto con aspecto juvenil y lampiño - en recuerdo del apuesto joven que entró a servir en la corte de Nabucodonosor -, como barbado y por tanto con un aire más maduro, ya se encuentre sedente o de pie, lo habitual es que adopte en su iconografía una actitud más tran- quila ante los leones, bien levantando sus manos como si estuviese orando, pensativo o dejándose lamer por las salvajes fieras manos o pies ${ }^{105}$. Llama la atención además que su iconografía sea tan opuesta a la del auténtico e incontrovertible Daniel del pilar de los profetas del Pórtico que, en efecto, tiene una imagen juvenil, sin barba, risueña y sin nada que ver con la brutal y vigorosa figura del parteluz ${ }^{106}$ (fig. 14). Incluso aceptando la suposición de que los animales monstruosos del basamento de la izquierda tengan que ver con las cuatro bestias de sus sueños - en el Pórtico, son, no obstante, bastantes más -, tendrían sentido en relación con el auténtico Daniel de la parte alta y no con el hombre del basamento que aparece aplastado por la arquitectura, fusionándose en un todo con los leones y en una actitud de evidente sometimiento y castigo; en modo alguno son aspectos que convengan a una figura tan venerable y sagrada como la del famoso profeta bíblico que, maduro o juvenil, suele ofrecer un aspecto más honorable ${ }^{107}$.

Hércules ha sido otra de las propuestas que han salido a escena en relación con la figura del hombre fornido del parteluz; la primera vez, creo, en una publicación de Ángel del Castillo que, sin embargo, no llegó a argumentar ${ }^{108}$, y la segunda sólo sugerida, aunque con mucha agudeza, por Serafín Moralejo, que saca en su apoyo un texto muy expresivo del Códice Calixtino ${ }^{109}$. Con posterioridad a este hecho, yo mismo he vuelto 
a insistir sobre esta identificación, basándome en que estaría perfectamente justificada por las claras y antiguas relaciones del héroe clásico con la Península Ibérica, estar la figura en un punto clave y capital del santuario del Apóstol que era considerado el patrón de las Españas - en la base de la columna del parteluz donde está la figura sedente de Santiago que conduce directamente hacia la Gloria - y porque el personaje podría asociarse perfectamente con la Monarquía Hispánica, con la imagen de la fuerza y, claro está, tratándose de Hércules, con el gran héroe que sabemos dominó al león de Nemea ${ }^{110}$. Es decir, que muy bien podría relacionarse la figura con un portal, como el de la Gloria, que estaba en los confines de España, que era obra de patrocinio real y de un rey, como Fernando II, que no dudaba en autoproclamarse "Rey de la Españas" para de este modo recordar su preeminencia sobre todos los demás soberanos ibéricos ${ }^{111}$. $Y$ en este sentido conviene recordar asimismo que Moralejo ha querido ver relaciones del pórtico compostelano con los "portails royaux" franceses, que aquí cabría interpretar en clave nítidamente española112.

La relación de España con Hércules viene, de hecho, desde la misma Antigüedad, pues se asocia al héroe tebano con las Columnas de Hércules de Gibraltar113, con la victoria sobre el rey y tirano Gerión ${ }^{114}$ y aún se llegó a afirmar que había muerto en nuestro país y que sus restos estaban depositados en un templo de Cádiz, - la relación gaditana con Hércules justifica, de hecho, que su escudo heráldico esté presidido por la figura del héroe tebano agarrando con sus brazos las bocas de dos leones como en la base del parteluz del Pórtico (fig. 15) - tal como sostiene el escritor latino Pomponio Mela115 nacido, por cierto, en Tingentera, actual Algeciras. Con posterioridad, a medida que la idea de España se iba de nuevo recomponiendo tras la invasión musulmana, fueron surgiendo también las primeras crónicas que querían contar, ya con argumentos históricos o con relatos fabulosos, la historia de nuestro país que alcanzaría su momento álgido con De Rebus Hispaniae del arzobispo Jiménez de Rada y de la época de Fernando III116, la Estoria de Espanna'17 de Alfonso X y la General Estoria del mismo rey ${ }^{118}$ que fueron escritas en la plenitud del siglo XIII; por cierto en los reinados de dos monarcas que eran, respectivamente, nieto y biznieto de

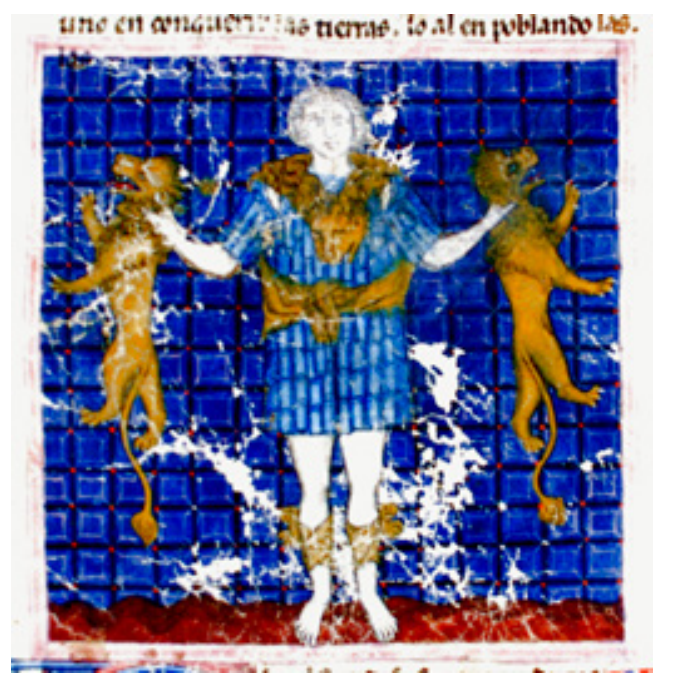

Fig. 16. Hércules estrangulando a dos leones en la selva Nemea. Estoria de Espanna. Biblioteca del Real Monasterio de El Escorial, ms.Y.I.2, fol. 4.

Fernando II, el promotor del Pórtico. Antes de ellos, ya en el siglo X, la Crónica de Al-Rasi, seguramente remontándose a fuentes anteriores, cita los orígenes de España señalando que Espan, hijo de Jafet y nieto de Noé, habría sido el primer poblador y rey de España ${ }^{119}$ - de ahí el nombre que recibe el país ${ }^{120}$ - y el cabeza de una estirpe de muchos reyes de origen patriarcal, el último de los cuales sería precisamente el poderoso Gerión. Ya en el tiempo de este último, habría venido a España el "rey" griego Hércules, que tras luchar, vencer y matar a Gerión, conquistaría todo el país poniéndose a la cabeza de una nueva estirpe de reyes españoles, esta vez de origen griego ${ }^{121}$. No solo eso nos cuenta Al-Rasi, sino que también habría sido Hércules el responsable de que España se poblase de ídolos paganos tal como indica con estas palabras:

E nunca él [Hércules] tomó tierra que non pusiese luego sus ymagines e sus señales muy marauillosas; e estas ymágenes eran en figura de toros e dellas de cavallos e dellas de cabrones; e estas eran las ymagines a que ellos adorauan en aquella sazon ${ }^{122}$.

Con algunas diferencias, el resto de las historias mencionadas vuelven a insistir en los orígenes bíblicos de España - en estas crónicas el primer poblador de España sería Túbal, hijo de Jafet y nieto de Noé, mientras que Espan sería, por el contrario, el heredero de Hércules -, en la 


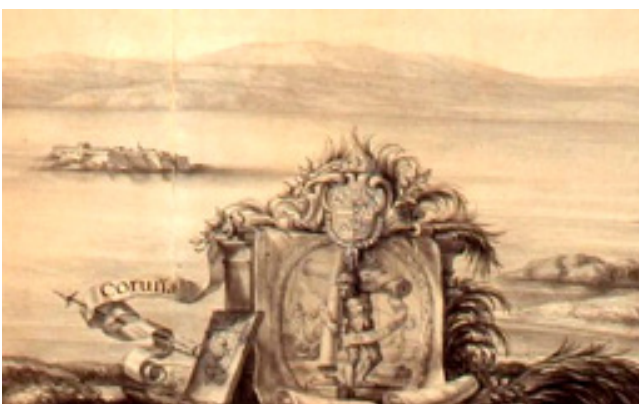

Fig. 17. Representación de Hércules sosteniendo el escudo de España en la vista panorámica de A Coruña del pintor Pier María Baldi de 1669. Florencia, Biblioteca Medícea Laurenziana, Ms. Med. Palat. 123/1, c. 162 (detalle)

figura de Gerión, pero sobre todo en convertir a Hércules en el gran protagonista de este tiempo primigenio que daba rumbo nuevo a nuestro país. Al mismo tiempo describen al héroe como griego, fuerte, conquistador, fundador de ciudades e incluso como una persona terrible que tuvo, no obstante, la sensatez de elegir como heredero y rey de España a un servidor suyo llamado Espan - Látin en la Crónica de Al-Rasi -, que sería el que daría nombre al país y al que siempre se considera, en cambio, un hombre noble, sabio, prudente y excelente gobernante ${ }^{123}$. Asimismo algunas crónicas como la Estoria de España y la General Estoria, citan la relación de Hércules con varios leones y no con el único y solitario león de Nemea que suelen citar mayoritariamente las fuentes clásicas y cuya piel conseguiría nuestro héroe como trofeo hasta convertirla en su atributo más característico ${ }^{124}$. Con todo, no debemos olvidar que, en cuestiones de narraciones míticas y legendarias, no es raro que cada autor introduzca cambios y variantes más o menos llamativos; de ahí que, en la Estoria de España ${ }^{125}$ y en la General Estoria de Alfonso X, en el apartado que el monarca castellano dedica a señalar "los leones que mato Ercules a manos", digan, en efecto, que habían sido tres, uno en el monte Partemio, según lo había indicado el escritor romano Ovidio, y los otros dos "en la selva Nemea". "E a los dos leones de Nemea tomolos Ercules en un ora con las sendas manos por las gargantas; e alçolos a amos de tierra. E de allí adelante le llamaron Ercules el domador de los leones e de las bestias fieras salvages" ${ }^{126}$. Estos relatos están datados aproximadamente entre las décadas de

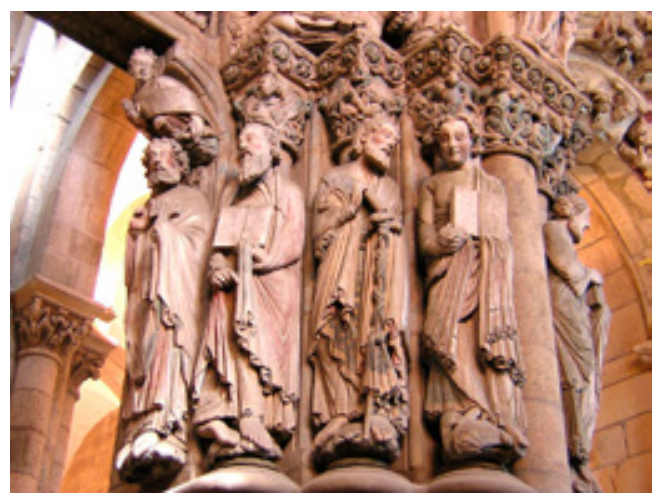

Fig. 18. Apóstoles de la jamba derecha del Pórtico de la Gloria, con las figuras de Santiago el Mayor y San Juan (Foto: https:// es.wikipedia.org)

1270 y 1280, aunque es muy probable que lo que cuentan se remonte a tiempos anteriores; y eso explica la figura del hombre dominando a dos leones del Pórtico de la Gloria que, por cierto, tiene mucha relación con el joven Hércules que, en una miniatura alfonsí de la propia Estoria de España, aunque en otra actitud dado su carácter de ilustración de un pasaje triunfal de su vida, aparece estrangulando a los dos leones nemeos ${ }^{127}$ (fig. 16).

Por otra parte, desde la Edad Media fue habitual asociar el origen de la monarquía española con el héroe tebano ${ }^{128}$; tradición ésta que siguió viva en la época moderna, lo que explica la presencia de las Columnas de Hércules en el escudo de España o la figura del propio héroe en muchas otras iconografías regias - en este sentido es interesante la representación que introduce el pintor italiano Pier María Baldi en la vista de A Coruña de 1669 pues, en alusión a su carácter herculino y a su condición de capital del Reino de Galicia por designio real, aparece la figura de Hércules sosteniendo sus columnas y sirviendo de soporte poderoso, como si fuera un atlante o telamón, al escudo de España que aparece con la corona real y el toisón de oro; además se aprecia apoyado en ambos el escudo del Reino de Galicia del que surge una flecha que lleva una cartela con el nombre de CORUÑA que señala hacia la ciudad y la Torre de Hércules, ambas fundación del héroe tebano según la leyenda (fig. 17) - que se advierten en el arte cortesano hasta casi el final del siglo XVIII'29. Por lo tanto, con todos estos datos, no me pare- 


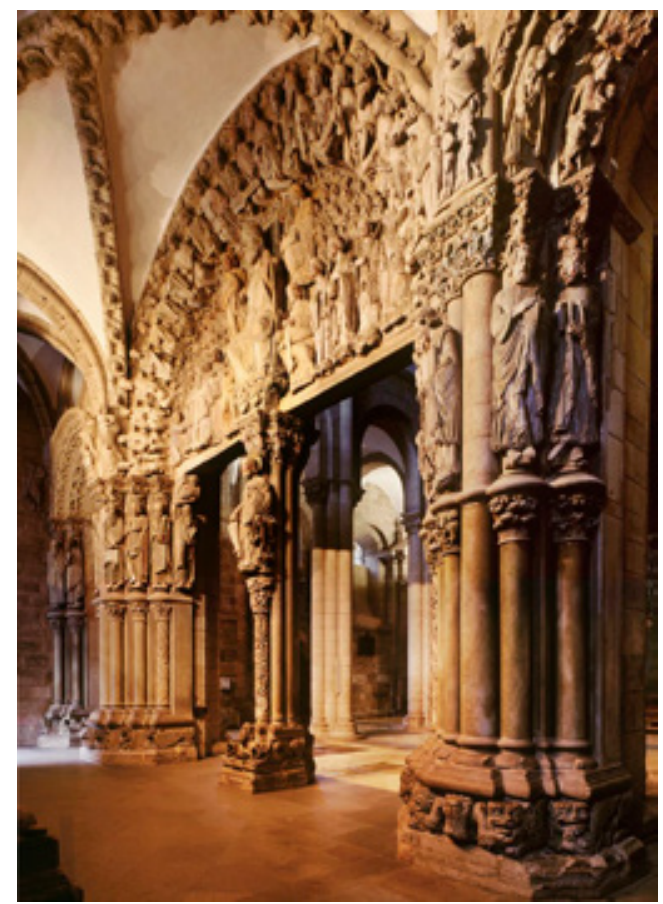

Fig. 19. Pórtico de la Gloria de la catedral de Santiago de Compostela (Foto: www.xaimecortizo.com)

ce incorrecto que la figura del Pórtico sea, como proponemos, Hércules ${ }^{130}$, que aquí estaría representado en su condición de conquistador del país, fundador de nuestra monarquía al haber dejado como heredero a Espan, pero también por ser el responsable de haber introducido en España la idolatría. Y esto explicaría que, pese a representar a nuestro país, en el Pórtico se lo represente en el basamento y aplastado por el parteluz que está presidido por la figura sedente del apóstol Santiago que, por cierto, lleva a los pies de su silla curul las figuras de dos sumisos leoncillos ${ }^{131}$.

Al mismo tiempo, la relación del Hércules aplastado con el Santiago sedente del parteluz, ha de verse como algo perfectamente coherente. Hemos dicho que Hércules representaría a España, pero una España antigua y ancestral, post-patriarcal - recuérdese que las crónicas más vinculadas a la monarquía consideraban que el primer poblador de España había sido Túbal, un nieto de Noé y que en la desaparecida fachada del Pórtico estaban varias representaciones de lo que se suponen eran viejos patriarcas bíblicos: ¿Abraham, Isaac...? - que adoraría por su culpa a los falsos ídolos, como ya hemos señalado. En cambio el apóstol Santiago, sería nuestro evangelizador, el encargado de venir a España por deseo expreso de Jesús para enseñarnos el evangelio y convertirnos a la nueva fe de Cristo ${ }^{132}$. Lo dicen claramente las dos cartelas que tradicionalmente se asocian a las dos figuras de Santiago el Mayor del Pórtico: "El Señor me envió [a España-Galicia]", decía al parecer la de la figura sedente ${ }^{133}-$ en la actualidad, no obstante, está completamente borrada- y "Dios dio crecimiento a esta región [España-Galicia]" la que aparece, en efecto, en el Santiago de pie que se encuentra en el pilar de la derecha ${ }^{134}$ hablando animadamente con su hermano San Juan, por cierto el autor del Apocalipsis (fig. 18). Todo esto nos hace recordar distintos párrafos del Calixtino que, no lo olvidemos, es de todos los códices compostelanos el más vinculado a la catedral y al templo jacobeo, una vez que sus diferentes libros son un compendio de todo lo relacionado con el culto del Apóstol'135. En él España y Galicia -tierras de evangelización y del último descanso de Santiago- tienen un protagonismo muy relevante; se las eleva y sublima, casi como si fuesen el pueblo o nación - "plebs", "gens" en el texto latino original del Calixtino - más queridos por Dios gracias precisamente a la predicación del Apóstol. Son continuos los elogios al país -"Regocíjate, España"136, "Dichosa eres España"137, "Vive justamente, nación española"138, "Feliz tierra de Galicia"139...-, a sus pobladores - " ¡Oh dichoso pueblo de España y de Galicia!"140- y a la Península que en diferentes ocasiones se compara con el Paraíso: “Eres feliz [España], porque en el clima eres semejante al Paraíso; pero eres más dichosa, porque has sido encomendada al paraninfo del cielo"141. Y por esta razón, junto a estos elogios, siempre aparece la figura de Santiago como artífice de esta especial querencia divina que explicaría, en efecto, que sobre el aplastado y pagano Hércules aparezca la figura serena y beatífica del apóstol Santiago que, al ser artífice de nuestra evangelización, nos conduciría por la vía más directa a la contemplación del Salvador que preside la Gloria con todos los bienaventurados (fig. 19).

Ya hemos dicho que todo esto tiene relación con párrafos muy escogidos que aparecen en el 


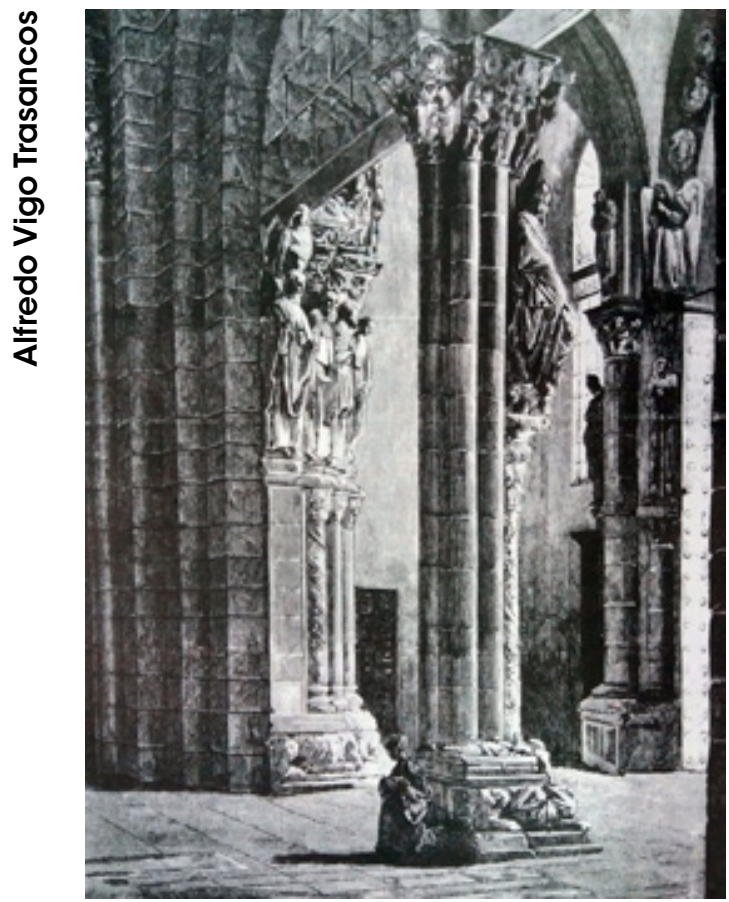

Fig. 20. Representación de la parte posterior del Pórtico de la Gloria basada en una fotografía de Th. Thompson (Foto: La Ilustración Gallega y Asturiana, 1879, p. 187)

Códice Calixtino y en particular en el sermón del papa León sobre Santiago que casi dice con palabras lo que el parteluz a través de sus principales figuras. Este es el texto:

Regocijate, España, ensalzada con semejante fulgor; salta de gozo, pues has sido salvada del error de la superstición. Alégrate, ya que por la visita de este huésped [Santiago] dejaste la ferocidad de las bestias y sometiste tu cerviz, antes indómita, al yugo de la humildad de Cristo. Mayores bienes te proporcionó la humildad de Santiago, que la ferocidad de todos tus reyes [léase Hércules y sus sucesores]. Aquella [la humildad de Santiago] te levantó hasta el cielo; éstos [los viejos reyes] te hundieron en el abismo [entiéndase los basamentos del Pórtico]. Ellos te mancillaron con el sacrificio de los ídolos; aquella te purificó, enseñándote el culto del verdadero Dios' ${ }^{142}$.

A esto se añade otro párrafo no menos elocuente que ya en su día señaló Moralejo:

En otro tiempo fuiste célebre [España] por las columnas de Hércules, según las vanas leyendas, más ahora con más felicidad te apoyas en la

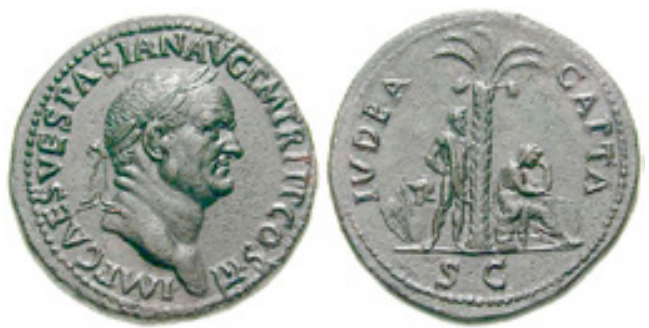

Fig. 21. Sestercio del emperador Vespasiano de la serie ludea Capta, acuñado en el año 71, en cuyo reverso se aprecian dos representaciones masculina y femenina del pueblo y la nación judía sometidos al yugo romano (Foto:https://es.wikipedia.org)

columna firmísima de Santiago. Aquellas, por el error pernicioso de la superstición, te ligaron al diablo [entiéndase los basamentos del Pórtico]; ésta, por su piadosa intercesión, te une a tu Criador; aquellas, como eran de piedra [ídolos paganos], aumentaban tu obcecación; ésta, puesto que es espiritual, adquirió para ti la gracia saludable. ${ }^{143}$

\section{licia! \\ ¡Oh dichoso pueblo de España y de Ga-}

Ahora bien, si todo lo que hemos dicho fuese cierto, como creemos ¿no tendría sentido que la figura posterior arrodillada del parteluz - que, por cierto, mira hacia oriente, hacia el altar mayor donde está la otra imagen sedente del Apóstol y hacia la capilla del Salvador que corona la cabecera de la catedral compostelana, lo que vendría a expresar en un recorrido longitudinal O-E lo mismo que se ha indicado en el recorrido vertical del "trumeau" del Pórtico: Hércules-SantiagoSalvador ${ }^{144}$ - fuese una representación renovada, cristiana, penitente y positiva que se opusiese al primitivo y barbudo Hércules pagano, violento y maligno del basamento del Pórtico?. Reforzaría esta opinión comprobar que la imagen juvenil, aristocrática y casi idealizada de la figura arrodillada podría representar una especie de "figura epónima" de un nuevo y joven "Pueblo de España y Galicia"/"Yspanie et Gallecie plebs" - no conviene olvidar que la primera mención histórica del arrodillado de hacia 1400 lo identificaba curiosamente con otra figura epónima: la mujer llamada "Compostela"145 - ahora convertido al cristianismo por Santiago que así se mostraría, en su nueva personalidad post-hercúlea, libre del peso de la arquitectura del parteluz, en actitud penitente y arrodillada - de ahí su gesto de darse 


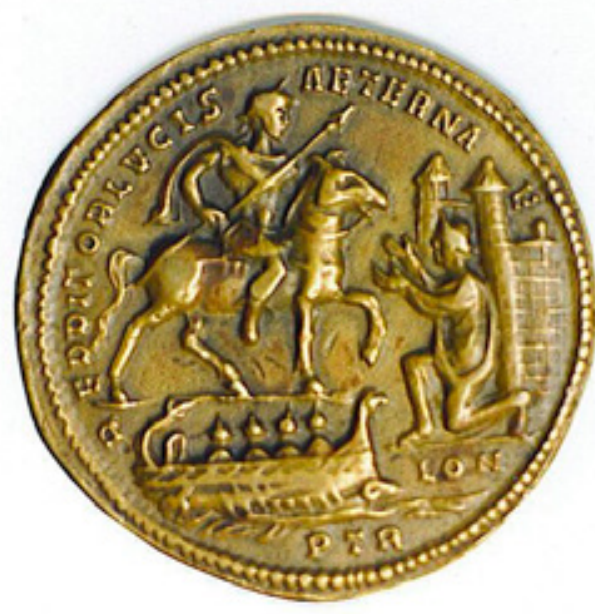

Fig. 22. El emperador Constancio Cloro entrando victorioso en Londres con la representación de la ciudad (LON) suplicante a sus pies (Foto:http://newepicurean.com)

un golpe en el pecho de arrepentimiento - con elegante vestido ante su santo patrono Santiago y ante su supremo Hacedor representado por el Salvador, en ambos casos dispuestos, como ya indicamos, en el altar mayor y en la capilla que preside la cabecera del templo apostólico al fondo de la girola. Y esto parecen sugerirlo, en efecto, dos nuevos párrafos del Calixtino, esta vez sacados del sermón del papa Calixto y que se encuentran en el Veneranda dies. Uno de ellos es el siguiente:

¡Oh dichoso pueblo de España y de Galicia, honrado con el poder de tan gran príncipe!; exaltado no por el mérito de tu bondad sino por el de tan glorioso Apóstol. Él te decoró, él te adornó, él te hizo feliz, él te honró. Tu noche, que no tenía día, se ha convertido en antorcha de la verdadera fe, cuyo esplendor no es posible explicar con palabras. Tú, que antes no tenías la gracia, ahora se te concede abundantemente. Antes ignorabas a tu Criador; ahora por tu Apóstol, conoces a tu Hacedor. Antes estabas sumergida en el error; ahora has sido levantada a la fe apostólica. Antes estabas entregada a las leyes vanas; ahora has aprendido las enseñanzas de libertad. Abjuraste lo que eras y comenzaste a ser lo que no eras. Tú, que habías fabricado templos inmundos, ahora adoras al verdadero Dios. Tú, que yacías en el estiércol de la infidelidad, ahora brillas en la fe apostólica ${ }^{146}$.
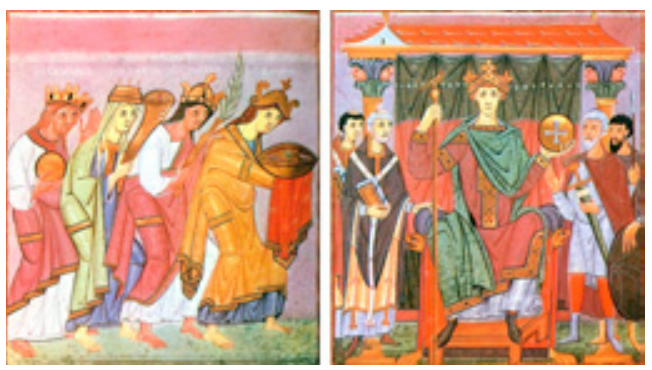

Fig. 23. Las provincias imperiales rindiendo pleitesía al emperador Oton III entronizado y rodeado de miembros de la nobleza y el clero. Evangeliario de Oton III, Reichenau, ca. 1000. (Foto: httpsupload.wikimedia.org)

El otro párrafo, que hemos señalado, prosigue de este modo:

Ruega, pues, pueblo de Galicia, con nos al Apóstol del Señor, para que, a su venerable maestro Cristo Rey, que se sienta en el cielo suplicándole constantemente por nuestros cotidianos delitos, interceda para que podamos despreciar lo terreno y amar lo celestial, para tener como abogado en el último día al que creemos que se ha de sentar sobre el duodécimo asiento y que ha de juzgar a las doce tribus de Israel, para que merezcamos ser colocados con él, concediéndonoslo el Señor ${ }^{147}$.

En otras palabras, creo que podríamos afirmar que estos dos textos están directamente relacionados con lo que vemos representado en el eje del parteluz del Pórtico de la Gloria presidido por el Salvador sedente y coronado como rey en su Gloria, con los bienaventurados de todas las naciones - "omnes populi" - contemplándolo, al apóstol Santiago como abogado mediador y a su querido Pueblo o Nación Española y Gallega, antes y después de su conversión a la Nueva Fe, implorando su socorro y salvación en el último Día (fig. 20).

Por lo demás, no era infrecuente en la iconografía antigua y preferentemente grecorromana la representación de figuras que aludiesen a tierras, naciones, provincias, ciudades o pueblos. Lo común era que aquellas fuesen, por lo general, identificadas por nobles matronas como las que hacen alusión a Hispania, Dacia, Judea o Britania en viejas monedas romanas (fig. 21) o a ciudades concretas como Londinium/Londres en la que conmemora la victoria de Constancio Cloro sobre Alecto y en donde la ciudad del Támesis aparece como una señora arrodillada ante las murallas 


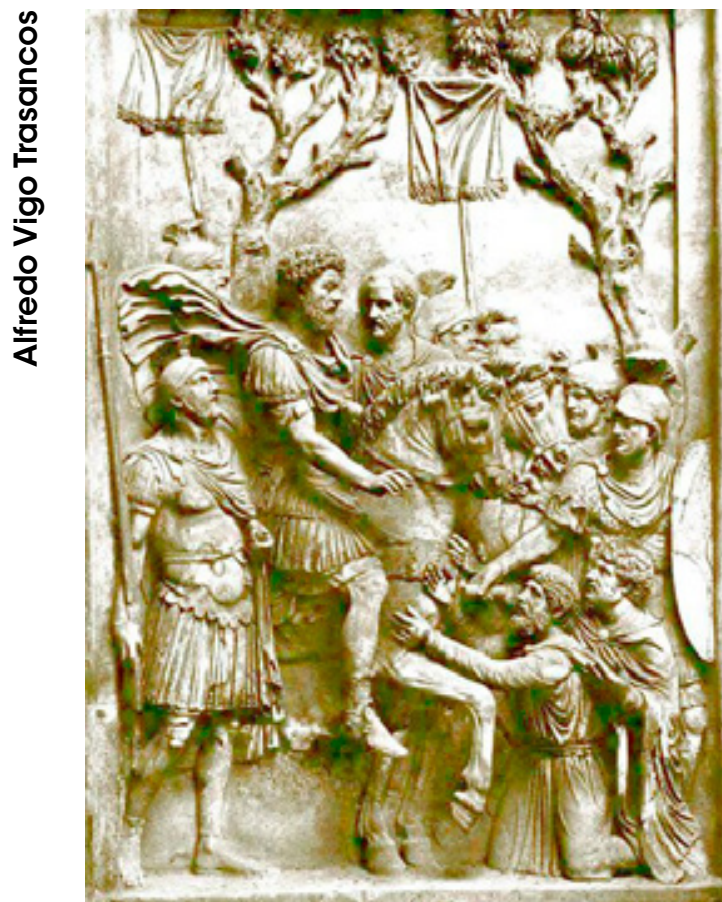

Fig. 24. Bárbaros cautivos arrodillados suplicando piedad a los pies del emperador Marco Aurelio montado a caballo, ca. 176-180, Roma, Museos Capitolinos (Foto: https://s-mediacacheak0.pinimg.com)

y a los pies del emperador a caballo suplicando su piedad (fig. 22). Ya en la plenitud medieval, entre el final de la época carolingia - ca. 870 - y el momento capital del período otoniano - ca. 1000 -, merecen también recordarse las figuras femeninas que, de pie, elegantemente vestidas, con coronas y en actitud de pleitesía hacia el emperador, representan las provincias imperiales 148 y que aparecen, respectivamente, en el "Codex Aureus" de San Emmeram, en el "Registrum Gregorii" de Otón II y en los Evangelios de Otón III (fig. 23) ${ }^{149}$. Suponen, sin duda, un testimonio iconográfico intermedio entre la época romana y la que nosotros estudiamos - aquí también es de interés destacar que, según la Historia de Espanna de Alfonso X, el nombre de la ciudad de A Coruña, fundada por Hércules, se debería a que su primera pobladora fue una mujer llamada Crunna - lo que les da un valor muy relevante. Por el contrario, la representación de los "pueblos" en la cultura romana parece preferir mayoritariamente iconografías masculinas como las que se

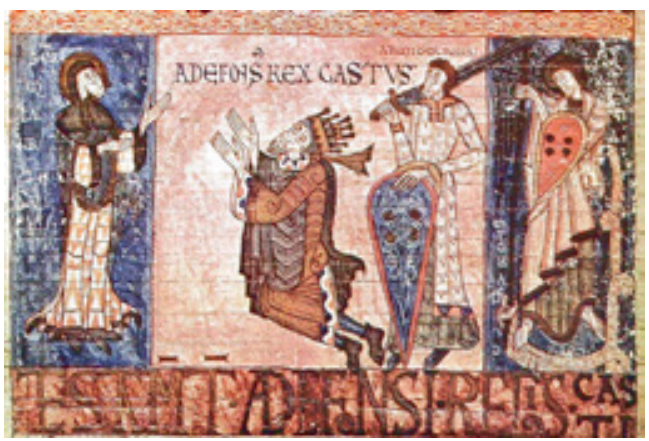

Fig. 25. Representación del rey Alfonso II el Casto arrodillado y suplicante ante el Salvador y los apóstoles. Miniatura del Liber Testamentorum Ecclesiae Ovetensis (detalle), ca. 1118 (Foto:https://upload.wikimedia.org)

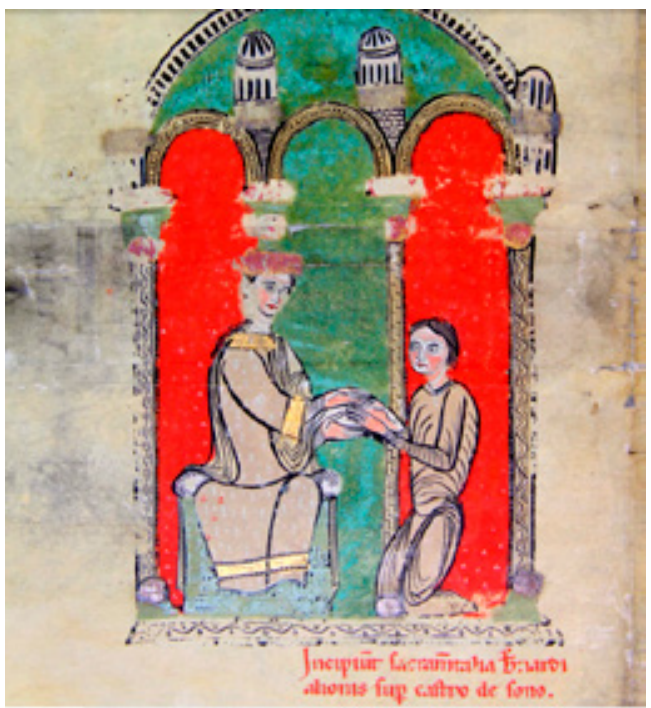

Fig. 26. Juramento de fidelidad de un vasallo a su Señor. Liber Feudorum Maior, fol. 116 del libro segundo, ca. $2^{a}$ mitad del s. XII, Archivo de la Corona de Aragón (Foto: www.mecd.gob.es)

ven, por ejemplo, en la estatua de guerrero galo de Vachères que se guarda en el museo Calvet de Avignon o en relieves de la columna Trajana o de la época de Marco Aurelio, en donde el pueblo germano vencido vuelve a aparecer arrodillado y suplicante ante la imagen ecuestre del emperador que se muestra ante ellos en una actitud triunfal (fig. 24). Es indiferente que, en ocasiones, estos se humillen hincando en el suelo una sola rodilla o las dos como en los casos que estamos comentando. No es fácil, en cualquier caso, encontrar representaciones de este tipo concatenadas entre los siglos II y XII - ¿se apreciará esta diferencia 
iconográfica entre "pueblos" y tierras/naciones/ provincias/ciudades en las dos figuras masculina y femenina que aparecen sometidas al emperador en las monedas de la serie Judea Capta de Vespasiano o en la placa principal del Díptico Barberini datados en los siglos I y VI?. Con todo, tampoco debe olvidarse en la figura del penitente la tradición iconográfica del peregrino contrito que lleva la mano al pecho en acto de arrepentimiento - como se aprecia en alguno de los esculpidos en la iglesia de Santiago de Turégano ya señalada o del rey o vasallo medieval que se postra ante su Supremo Soberano o Señor, tal como se ve en las miniaturas que ilustran el Liber Testamentorum Ecclesiae Ovetensis - se representa en efecto a Alfonso II el Casto arrodillado y suplicante ante el Salvador y los Apóstoles (fig. 25) - o el Liber Feudorum Maior (fig. 26), ambos del siglo XII, que son, por cierto, muy próximas en el tiempo al "Santo dos Croques".

Finalmente, queda por mencionar la relación de todo lo señalado con la figura del monarca Fernando II. Lógicamente, aunque fue su promotor financiero, difícilmente sería su mentor ideológico ${ }^{150}$; pero una referencia a la monarquía, a España, a Galicia y a su patrono Santiago era algo que no se podía soslayar, pues no debemos olvidar que el monarca se consideraba rey de todas las Españas ${ }^{151}$ y un soberano que consideró a Compostela la ciudad principal de su reino, en detrimento de León, y a la catedral de Santiago en el más destacado templo de su monarquía por ser el Apóstol el patrono de todos sus reinos - "caput Hispaniae"152. Incluso es muy probable que, desde el mismo momento en que convirtió a Mateo en el maestro de obras vitalicio de la catedral - 1168 -, lo hiciese convencido de que iba a realizar una obra excepcional en aquel lugar que había elegido para su última morada. Se enterró, en efecto, en la catedral en marzo de $1188^{153}$, aunque como sabemos en una discreta capilla que estaba situada en el lado izquierdo del interior de la puerta norte de Azabachería en donde se dispuso el panteón real y, mucho después, la capilla de Santa Catalina154. Un espacio, por cierto, estrecho, secundario y de poca dignidad para un rey que tanto hizo por Santiago, su catedral y el Reino de Galicia. Por eso que me pregunte, al igual que Ramón Yzquierdo y Gerardo Boto, si la cripta terrena del Pórtico, dispuesta como está en el subsuelo de la Gloria, no estaría destinada para servir de mausoleo del monarca - no olvidemos que en la parte principal del Pórtico en una de las columnas se ve la resurrección de los muertos y en el arco de la epístola el Juicio Final de donde pasan los justos y bienaventurados a la contemplación del Salvador - aunque después, por razones que se nos escapan, nunca fuese habilitada como panteón del rey ${ }^{155}$. Y este hecho creo que también insistiría en la idea de ver en el Pórtico de la Gloria un auténtico e hispánico Portal Real dispuesto como gran cierre occidental del templo de Santiago en la que era, de hecho, la ciudad principal de todos sus reinos ${ }^{156}$.

Llegados hasta aquí, no debemos olvidar las letras grabadas que aparecen en la parte posterior del basamento del parteluz y que ya hemos señalado. Se las ha interpretado preferentemente como alusivas a F(ECIT) o a F(ERNANDUS), pero lo cierto es que actualmente poco más se puede leer que una $\mathrm{F}$ seguida de lo que pudiera ser, no sin ciertas dudas, o una E o una $\mathrm{S}$ o incluso un signo más indescifrable. Nada, pues, que pueda aportar una lectura demasiado certera. Tampoco es seguro que, por su posición retrasada en la base del parteluz, tenga que ver necesariamente con el "Santo dos Croques" pues éste llevaba en la mano, no lo olvidemos, su propia cartela con la palabra o texto que en su día resultaría perfectamente aclaratorio. Por lo tanto, quedan las citadas letras como una incógnita a resolver entre otras muchas que todavía guarda el Pórtico de la Gloria. 


\section{NOTAS}

*Antes de dar paso a todo el aparato crítico que aquí se enumera, quiero dar las gracias a mi compañero Julio Vázquez Castro, pues desinteresadamente y con gran generosidad se prestó a leer y revisar este artículo y a aportar mucha información y sugerencias que sin duda lo han enriquecido de manera significativa. De hecho, me ayudó en cuestiones no sólo de bibliografía, sino en aspectos iconográficos que han resultado claves para la mejor comprensión de lo que aquí se expone. También debe constar que el presente trabajo forma parte del proyecto de investigación titulado "Memoria, textos e imágenes. La recuperación del patrimonio perdido para la sociedad de Galicia", concedido para el trienio 2015-2017 por el Ministerio de Economía y Competitividad. Tiene como código de referencia HAR2014-53893-R. Asimismo se ha beneficiado de la ayuda económica del Plan Galego IDT concedido por la Consellería de Cultura, Educación e Ordenación Universitaria para el bienio 2017-2018, que tiene como código: ED431B 2016/003.

${ }^{1}$ NEIRA DE MOSQUERA, A.: "Historia de una cabeza. 1188", en Antonio Neira de Mosquera, Monografías de Santiago y dispersos de temas compostelanos (1844-1852), Santiago, Bibliófilos gallegos, 1950, p. 37. La edición original se publicó en Santiago, en la Imprenta de la viuda de Compañel e Hijos en 1850. Existe reciente reedición, con introducción de José Daniel Buján, publicada en Santiago de Compostela, Ara Solis-Consorcio de Santiago, 2000.

${ }^{2}$ LÓPEZ FERREIRO, A.: El Pórtico de la Gloria. Estudio sobre este célebre monumento de la basilica compostelana, Santiago, 1893, p. 40 ( $1^{\text {a }}$ ed. de 1886).

${ }^{3}$ Además de los distintos estudios que se citan en las notas que se incluyen en este artículo, como obras de referencia de carácter general pueden consultarse MORALEJO ÁlVAREZ, S.: "Le Porche de la Gloire de la Cathédrale de Compostelle: problèmes de sources et de interprètation", Les Cahiers de SaintMichel de Cuxa, Centre permanent de Recherches \& d'Études Préromanes \& Romanes, juillet 1985, pp. 92-110. Ree- ditado en Patrimonio artístico de Galicia y otros estudios. Homenaje al prof. Dr. Serafín Moralejo Álvarez, I, coordinado por A. Franco Mata, Santiago, 2004, pp. 307-318; del mismo autor: "El Pórtico de la Gloria", en FMR, Franco María Ricci 199, 1993, pp. 28-46. Reeditado en Patrimonio artístico..., op. cit., II, pp. 281-284; CASTIÑEIRAS GONZÁLEZ, M.: El Pórtico de la Gloria, Madrid, San Pablo, 1999 e YZQUIERDO PERRíN, R.: El maestro Mateo y el Pórtico de la Gloria en la catedral de Santiago, León, Edilesa, 2010.

${ }^{4}$ SÁNCHEZ AMEIJEIRAS, R.: "El entorno imaginario del rey: cultura cortesana y/o cultura clerical en Galicia en tiempos de Alfonso IX", en Alfonso IX e a súa época. Pro utilitate regni mei, coordinado por F. López Alsina, A Coruña, Concello da Coruña, 2008, p. 313, ha sugerido que las claves de las tres bóvedas del cuerpo principal del Pórtico de la Gloria (los otros dos serían la cripta y la tribuna alta) pudiesen llevar lámparas o lumbreras que, junto con los florones de la bóveda central que representarían estrellas, aludirían a la caída de los astros, siguiendo el evangelio de San Mateo que anuncia el pasaje previo al Juicio Final (MATEO, 24, 29-44: La venida del Hijo del Hombre. "E inmediatamente después de la tribulación de aquellos días, el sol se oscurecerá, y la luna no dará su resplandor, y las estrellas caerán del cielo y las potencias de los cielos serán conmovidas. Entonces aparecerá la señal del Hijo del Hombre en el cielo; y entonces lamentarán todas las tribus de la tierra, y verán al Hijo del Hombre viniendo sobre las nubes del cielo con poder y gran gloria. Y enviará sus ángeles con gran voz de trompeta, y juntarán a sus escogidos, de los cuatro vientos, desde un extremo del cielo hasta el otro... Pero del día y la hora nadie sabe, ni aun los ángeles de los cielos, sino sólo mi Padre. Mas como en los días de Noé así será la venida del Hijo del Hombre... Por tanto, también vosotros estad preparados; porque el Hijo del Hombre vendrá a la hora que no pensáis"). No obstante, esto que podría tener algún sentido en la bóveda de la derecha donde se representa, en efecto, el Juicio Final en toda su crudeza, difícilmente puede ser asumido para la bóveda central donde se encuentra la visión resplandeciente de la Gloria en el contexto de la Jerusalén Celestial que es, en los tiempos que se narran en los textos bíblicos, un momento posterior y apoteósico en el que los bienaventurados contemplan en todo su esplendor la figura radiante del Salvador.

5 JUAN, Apocalipsis, 21,23: "La ciudad [Santa] no tiene necesidad de sol ni de luna que brillen en ella; porque la gloria de Dios la ilumina y el Cordero es su lumbrera"; JUAN, Apocalipsis, 22,5: "No habrá allí más noche; y no tienen necesidad de luz de lámpara, ni de luz del sol, porque Dios el Señor los iluminará a los bienaventurados".

${ }^{6}$ MORALEJO ÁlVAREZ, S.: "La imagen arquitectónica de la catedral de Santiago de Compostela", en Atti del Convengo Internazionale di Studi: I/ Pellegrinaggio a Santiago di Compostella e la Letteratura Jacopea, Perugia 23-2425 settembre 1983, Perugia, 1983, pp. 37-61. También en Patrimonio artístico de Galicia ..., op. cit., I, p. 243.

7 JUAN, Apocalipsis, 22,1-3: "Después me mostró un río limpio de agua de vida resplandeciente como cristal, que salía del trono de Dios y del Cordero. En medio de la calle de la ciudad, y a uno y otro lado del río, estaba el árbol de la vida que produce doce frutos, dando cada mes su fruto; y las hojas del árbol eran para la sanidad de las naciones. Y no habrá más maldición y el trono de Dios y del Cordero estará en ella, y sus siervos le servirán, y verán su rostro, y su nombre estará en sus frentes. No habrá allí más noche; y no tienen necesidad de luz de lámpara, ni de luz del sol, porque Dios el Señor los iluminará y reinarán por los siglos de los siglos".

${ }^{8}$ Una alusión a la presencia del "árbol de la vida" en el Pórtico de la Gloria la mencionan SCHOTBORGH, F. y SCHLÖR, W.: El Pórtico de la Gloria de Santiago de Compostela, Barcelona, Herder, 1980, pp. 13-14 y lo ven en el propio árbol de Jesé y en todas las figuras coronadas de los justos del Antiguo Testamento y en los 24 ancianos apocalípticos que llevan también la "corona de la vida" mencionada por el Apocalipsis (JUAN, Ap. 2,10: "Permanece fiel hasta la muerte y te daré la corona de la vida"). Curiosamente no mencionan la decoración de la bóveda central que 
sería una representación clara de sus frutos.

${ }^{9}$ En esta misma línea y con el mismo significado metafórico, aparecen en otras muchas iglesias gallegas en donde se ve claramente el influjo del Pórtico compostelano. Suelen representarse bien como grandes flores de las que brotan jugosos frutos o simplemente como frutos en formas de piña que siguen la forma curva de la arquivolta exterior: San Estevo de Ribas de Miño, Carboeiro, etc.

10 JUAN, Apocalipsis, 21,6: "Y me dijo: Hecho está. Yo soy el Alfa y la Omega, el principio y el fin. Al que tuviere sed, yo le daré gratuitamente de la fuente del agua de la vida".

11 "VIDI CIVITATEM SANCTAM HIERUSALEM DESCENDENTEM DE CAELO A DEO". Cit. por YARZA LUACES, J.: El Pórtico de la Gloria, Madrid, Alianza editorial, 1984, pp. 38-39.

${ }^{12}$ Con razón indica el autor que "Si hubiesen perdurado todas ¿no estarían formando por sí mismas la síntesis interpretativa que en los comienzos habló con claridad a cuantos aquí llegaban?". Lamentablemente nadie se preocupó de recogerlas cuando aún se estaba a tiempo. Vid. DÍAZ FERNÁNDEZ, J. Ma: "Teología del Pórtico de la Gloria", en Los instrumentos del Pórtico de la Gloria. Su reconstrucción y la música de su tiempo, vol. I, coord. por J. López Calo, A Coruña, Fundación Barrié, 1993, p. 24

${ }^{13}$ Asimismo señala WARD, M. L.: Studies of the Portico de la Gloria at the catedral of Santiago de Compostela, Ann Arbor, University Microfilm International, 1986 (el texto fue escrito en 1978), p. 104, que los textos que una vez acompañaron estas imágenes tuvieron que haber proporcionado una gran información sobre el programa escultórico que se perdió para siempre y que es imposible de recrear.

${ }^{14}$ La primera referencia a la temática del Pórtico que conocemos es de finales del siglo $\mathrm{XV}$ y responde a un comentario que hace el obispo armenio Mártiros de Arzendjan (1489-1491) en su visita a Santiago. Dice lo siguiente: "Tiene [la catedral] cuatro pórticos ... Delante del Pórtico oeste hay una fuente de la que fluye agua hacia abajo; so- bre el pórtico este está sentado Cristo en un trono, con una representación de los acontecimientos después de Adán y de todo lo que sucederá al fin del mundo. La totalidad de la representación es $\tan$ extraordinariamente hermosa que es imposible describirla". Cit. por HERBERS, K. y PLÖTZ, R.: Caminaron a Santiago. Relatos de peregrinaciones al "fin del mundo", Santiago, Xunta de Galicia, 1999, p. 137. A su vez, en 1610, CASTELLA FERRER, M.: Historia del Apóstol de lesus Christo Sanctiago Zebedeo, Patrón y Capitán General de las Españas, Madrid, 1610, , p. 324, cita el Pórtico brevemente para diferenciar entre año y era, señalando que había sido obra de Mateo y dando cuenta, en parte, de la inscripción de los dinteles: "Confiesso ser opinion assentada en nuestra España, contarse treynta y ocho años la Era antes del Nacimiento del Señor, y desto hallamos historias , y en piedras se halla noticia, como sobre la puerta principal de la Apostolica Iglesia de Santiago está este letrero, diziendo como se acabó aquella portada, y la hyzo el Maestro Matheo: Anno ab Incarnatione Domini M.C.LXXXVIII. Era M.CC. XXVI die kalendas aprilis". Años después, en 1651, en un documento de pago al pintor Crispín de Evelino se indica que se le pagan 130 ducados "por pintar y encarnar las caras, pies y manos de las figuras que están en la portada principal desta Sta. Iglesia que llaman de la Trinidad y las del pilar de mármol en que está la descendencia de Nra. Señora y la Sta. Berónica". La cita la dio a conocer BUSCHBECK, E.H.: Der Pórtico de la Gloria von Santjago de Compostela, Berlín-Viena, 1919, p. 9. Nuestra cita está sacada, no obstante, de CASTIÑEIRAS GONZÁLEZ, M.: Op. cit., p. 62. Finalmente, en 1673, el italiano LAFFI, D.: Viaggio in ponente a San Giacomo di Galitia a Finisterrae, edizione e note a cura di Anna Sulai Capponi, Perugia, Universitá, 1989, p. 203, vuelve a señalar el interés del Pórtico indicando: "Sopra la medesima porta vi è il Giudicio Finale, tutto in figure di mezzo rilievo, cosa bellissima da vedere".

${ }^{15} \mathrm{El}$ primero en mencionar esta glosa creo que fue VILLAAMIL Y CASTRO, J.: La catedral de Santiago. Breve descripción histórica, Madrid, Tipografía de la revista de Archivos, 1909, pp.
85-86: "De muliere nomine Compostela cujus imago est in poste ad caput Petri moniz archiepiscopi", aludiendo al sepulcro que estaba allí. Una buena fotografía de esta anotación puede verse en VALLE PÉREZ, C.: "Mateo. Da Historia á lenda", en O Pórtico da Gloria e o seu tempo. Catálogo da exposición conmemorativa do VIII centenario da colocación dos dinteis do Pórtico da Gloria da Catedral de Santiago de Compostela. Santiago do 16 de setembro ó 17 de novembro de 1988, Santiago, Xunta de Galicia, 1988, p. 159.

${ }^{16}$ La tumba original del arzobispo se habría colocado allí tras su muerte en 1224. Estaba, en efecto, a los pies del Santo dos Croques" y tenía supuestamente el bulto yacente y broncíneo del prelado.

${ }^{17}$ La inscripción de la lápida actual dice "Renovóse el año de 1774". Cit. por ZEPEDANO Y CARNERO, J. Ma: Historia y descripción arqueológica de la basílica compostelana, Lugo, Imprenta de Soto Freire, 1870. Cito por la reedición publicada en Santiago por la Xunta de Galicia en 1999, p.173.

${ }^{18}$ MORALEJO ÁlVAREZ, S.: "Prólogo", en MATEO SEVILLA, M.: El Pórtico de la Gloria en la Inglaterra Victoriana. La invención de una obra maestra, Santiago, Museo Nacional das Peregrinaciones, 1991, p. 13.

${ }^{19}$ MORALEJO ÁlVAREZ, S.: Ídem, ídem. y CASTIÑEIRAS, GONZÁLEZ, M.: Op. cit., p. 23, han sugerido que esta mujer llamada Compostela y mencionada hacia 1400 en la glosa ya citada, podría tener relación con la matrona del mismo nombre que se menciona en el Códice Calixtino (I, XVII): "Otros dicen que el Apóstol echó una maldición a la tierra de Galicia de que no diera más vino en adelante, porque una matrona llamada Compostela, según cuentan, embriagada con vino, se durmió y no anunció al Señor, que visitó la Basílica, mientras él dormía en su regazo. Pues le había encargado el Apóstol, según cuentan, que le avisase cuando el Señor viniese". Vid. Liber Sancti Jacobi. Codex Calixtinus. Traducción por los profesores A. Moralejo, C. Torres y J. Feo, Santiago, 1951, p. 185. Cito por la reedición de Santiago, Xunta de Galicia, Consellería 
de Cultura, 2004, revisada por J.J. Moralejo y $\mathrm{M}^{\mathrm{a}} \mathrm{J}$. García Blanco.

${ }^{20}$ ANDRADE, D.: Excelencias, antigüedad y nobleza de la Arquitectura, Santiago, Antonio Frayz, 1695. Sobre su papel reivindicativo vid los recientes estudios de TAÍN GUZMÁN, M.: Comentario a las Excelencias, antigüedady nobleza de la arquitectura de Domingo de Andrade, Santiago, Xunta de Galicia, 1993 y VIGO TRASANCOS, A.: Barroco. La arquitectura sagrada de antiguo reino de Galicia (1658-1763), Santiago, Consorcio-Teófilo, 2012, especialmente pp. 86 y ss.

${ }^{21}$ MENDOZA DE LOS RÍOS, P.: Theatro Moral y Político de la Noble Academia Compostelana, Santiago, 1731.

22 RIOBÓO Y SEIJAS, A.: Análysis histórica, chronologica de la primitiva erección, progresos y diversas reedificaciones de la Santa Iglesia de Santiago, Santiago, Imprenta de D. Andrés Frayz, 1747, p. 26: "En cuyo tiempo [de Fernando II y Pedro Suárez de Deza] se fabricó hasta la puerta principal de occidente, que dista aora de la actual 7 varas castellanas, y un pie, y lo acredita la Inscripción gravada en su Lintel, que sirve ahora de arco a la vistosa representación de ambos Testamentos, Ilamada vulgarmente la Gloria, en la Era 1226. Año 1188 que se da al margen: Ann. Ab. Incarnatione Domini....".

${ }^{23}$ Vid. VIGO TRASANCOS, A.: La catedral de Santiago y la llustración. Proyecto clásico y memoria histórica (1757-1808), Madrid, Electa-Consorcio, 1999, pp. 126 y 156, nota 347.

${ }^{24}$ CEÁN BERMÚDEZ, J. A.: Diccionario histórico de los más ilustres profesores de las bellas artes en España, III, Madrid, Imprenta de la viuda de Ibarra, 1800, p. 97-98: "Mateo (El maestro) escultor y arquitecto a mediados del siglo XII. Construyó la catedral de Santiago de Galicia y la adornó con estatuas... Representan en el medio la gloria con el Salvador... y se figura a los lados el purgatorio y el infierno...El rey Fernando hizo mucho aprecio del mérito de este profesor, pues le concedió cien maravedís de renta al año en todos los días de su vida... Concluida la obra de la catedral se puso sobre las dos puertas de la fachada principal por dentro la inscrip- ción siguiente en caracteres antiguos: Anno ab incarnatione Dni...".

${ }^{25}$ LLAGUNO Y AMIROLA, E.: Noticias de los arquitectos $y$ arquitectura en España desde su restauración, ilustradas y acrecentadas por D. Juan Agustín Ceán-Bermúdez, Madrid, Imprenta Real, 1829, I, pp.31, 32, 33, 252, 343, 358. Es en la p. 32 donde aparece la mención más amplia: "Pero entre tantos artífices como desde el principio se emplearían en su construcción [catedral de Santiago], solo se halla memoria del que hizo la portada principal de la iglesia. Se llamaba maestro Mateo, y la concluyó en 1188, como parece por una inscripción, que copia Castellá Ferrer, lib. III, fol. 342".

${ }^{26}$ INCLÁN VALDÉS, J.M.: Apuntes para la historia de la Arquitectura y observaciones sobre la que se distingue con la denominación de gótica, Madrid, Ibarra, 1833, p. 65. De la catedral de Santiago solo indica que se había iniciado en 1082, que se había concluido en su cuerpo principal en 1128 "y enteramente en 1188".

${ }^{27}$ FORD, R.: A Handbook for Travellers in Spain and Readers at Home, London, John Murray, 1845. La visita de Richard Ford a Santiago tuvo lugar en junio de 1832.

${ }^{28}$ Manual del viajero en la Catedral de Santiago. Reseña histórica, Madrid, Imprenta de Don Baltasar González, 1847.

${ }^{29}$ CAVEDA, J.: Ensayo histórico sobre los diversos géneros de arquitectura empleados en España desde la dominación romana hasta nuestros dias, Madrid, Imprenta de D. Santiago Saunaque, 1848, p. 180: "El maestro Raimundo construía la catedral de Lugo...; el maestro Mateo, la portada de la catedral de Santiago". STIRLING-MAXWELL, W.: Annals of the Artists of Spain, vol. I, London, John Ollivier, 1848, p. 71.

${ }^{30}$ MELLADO, F. de P.: Recuerdos de un viaje por Galicia en 1850, Madrid, Establecimiento tipográfico de Mellado, 1850, p. 67.

${ }^{31}$ MATEO SEVILLA, M.: "El descubrimiento del Pórtico de la Gloria en la España del XIX", Actas del Simposio Internacional sobre "O Pórtico da Gloria e a arte do seu tempo", Santiago de Compostela, 3-8 de outubro de 1988,
Santiago de Compostela, Xunta de Galicia, Dirección Xeral de Cultura, 1991, pp. 457-477.

${ }^{32}$ MORAlejo Álvarez, S.: "Prólogo", en Mateo Sevilla, M....., op. cit., pp. 11-19.

${ }^{33}$ Op. cit.

${ }^{34}$ Op. cit., p. 40. Así lo indica, en efecto, el propio autor en las notas 1 y 11. Nota 1: "Este artículo fue escrito expresamente para nuestro amigo el distinguido pintor D. Genaro Pérez Villaamil quien ha copiado el Pórtico de la Gloria en su último viaje a Galicia, con la mayor exactitud e inteligencia". Nota 11: "Con la mayor satisfacción citamos un nombre propio en este lugar. El acreditado pintor D. Genaro Pérez Villaamil, natural de esta provincia, entre otras copias de monumentos que ha dibujado en Santiago a principios de 1848 , se debe contar la de este pórtico, como la primera obra monumental de la población".

${ }^{35}$ Sobre el cuadro en cuestión, fechado no obstante en 1849, vid. ARIAS ANGLÉS, E.: El paisajista romántico Jenaro Pérez Villaamil, Madrid, CSIC, 1986, pp. 144-145, 147 y 257. El autor documenta la estancia en Galicia del pintor ferrolano en distintos momentos de 1849. La ficha de catalogación del lienzo, que lleva el n 167 es la siguiente: El Pórtico de la Gloria de la catedral de Santiago de Compostela. Madrid. Palacio de la Moncloa (Patrimonio Nacional), lienzo 1,33x1, 82. Fechado: 1849.1851.

${ }^{36}$ Vid. VÁZQUEZ CASTRO, J.: "El rey de los incensarios. Víctor Hugo y el redescubrimiento romántico del Botafumeiro", Abrente, n 40-41, 1998, pp. 149-186.

${ }^{37}$ NEIRA DE MOSQUERA, A.: Op. cit., p. 35.

${ }^{38}$ Ídem, ídem, pp. 36-37.

${ }^{39}$ Íd., íd., pp. 37 y ss.

${ }^{40}$ RADA Y DELGADO, J. DE LA: Viaje de SS.MM. y AA. por Castilla, León, Asturias y Galicia, verificado en el verano de 1858, Madrid, Imprenta de Aguado, 1860, pp. 721-722: "Este pórtico... tuvo entre las diferentes cabezas que se encuentran en la Gloria el retrato del artista en actitud de sostener una columna". También identifica el "Santo dos Croques" con la imagen del 
Maestro Mateo: "El arquitecto, sin embargo, puso su estatua en el pavimento de la catedral, ... estatua en que viendo el vulgo el cumplimiento de un voto y la ofrenda del ingenio al poder divino, creyó que golpeando las cabezas de los niños en la de ella podría inspirarles elevados pensamientos. De ahí que aquella efigie sea conocida con el nombre de Santo dos Croques o Santo de las Cabezadas".

${ }^{41}$ IGLESIA, A. DE LA: "Estudios arqueológicos. La gloria de la catedral de Santiago", Galicia. Revista universal de este reino, n 16, La Coruña, 1861, p.242. Este artículo también puede consultarse en la reciente reedición de la obra completa del mismo autor titulada: Estudios arqueológicos, edición e introducción de M. R. Saurín de la Iglesia, Cuadernos de Estudios Gallegos, anexo XXXIX, Madrid, 2008, pp. 99-100.

${ }^{42}$ MATEO SEVILLA, M.: El Pórtico de la Gloria..., op, cit., p. 40.

${ }^{43}$ STREET, G.E.: Some Account of Gothic Architecture in Spain, London, John Murray, 1865. Existe traducción española, por la que cito: La arquitectura gótica en España, Madrid, Editorial Saturnino Calleja, 1914, pp. 170-171: "Todas las basas son muy vigorosas y, por lo general, descansan sobre monstruosos seres. La del parteluz presenta una figura humana que rodea con sus brazos el cuello de sendos monstruos alados y de abiertas fauces, mientras que por el otro lado del interior se ve una figura orando y arrodillada, que mira al este, siendo su tamaño mitad del natural aproximadamente".

${ }^{44}$ VILLAAMIL Y CASTRO, J.: Descripción histórico-artístico-arqueológica de la catedral de Santiago, Lugo, Imprenta de Soto Freire, 1866, pp. 98 y 110.

${ }^{45}$ Ídem, ídem, p. 113: "Santo dos croques: que el vulgo conoce con este nombre y que representa al Maestro Mateo, el arquitecto a quien se debe la soberbia construcción de este pórtico, ... con la mano derecha se golpea el pecho y con la izquierda sostiene un tarjetón en que se lee: ARCHITECTUS. El vulgo le profesa particular devoción y lleva a los niños para tocarles la cabeza a la del insigne maestro, en la creencia de que adquirirán grande desarrollo en sus facultades intelectuales y serán inspirados de elevados pensamientos, por lo cual llaman a esta estatua el Santo dos croques y también la "Santa de la memoria". El mismo autor vuelve a insistir en lo mismo en una publicación ligeramente posterior: VILLAAMIL Y CASTRO, J.: "La catedral de Santiago. Su historia y descripción, sus accesorios y mobiliario", El arte en España. Revista mensual del arte y de su historia, director D.G. Cruzada Villaamil, T.VII, Madrid, Imprenta de M. Galiano, 1868, p. 296. En esta ocasión sustituye "ARCHITECTUS" por "architectus".

${ }^{46}$ ZEPEDANO Y CARNERO, J. Ma : Op. cit., p. 182: "Al pie de la columna del centro y junto a la lápida funeraria del arzobispo D. Pedro Muñiz, se halla la estatua del arquitecto Mateo; con la mano derecha se golpea el pecho, y en la izquierda sostiene un tarjetón en que se lee: Architectus".

${ }^{47}$ D.B.C.F.A. (Bernardo Fernández): Reseña Histórica del Pórtico de la Gloria de la S. A. M. I. Catedral de Santiago, Imprenta de Manuel Mirás, 1870, p. 8: "El maestro Mateo se colocó de modo que pudiese prestar alguna ayuda a su señor, se puso como guardándole las espaldas, de rodillas y dirigiendo su vista hacia el altar del trascoro. Este es a quien el vulgo conoce con el nombre de Santo dos Croques, a quien se debe la soberbia construcción de este pórtico... con la mano derecha se golpea el pecho y con la izquierda sostiene un tarjetón en que se lee: ARCHITECTUS".

${ }^{48}$ Sobre las múltiples leyendas que se han asociado a la figura del Maestro Mateo es de utilidad la consulta de BOUZA BREY, F.: "El maestro Mateo en la tradición popular de Galicia", Compostellanum, IV, 1959, pp. 181-194. También VALLE PÉREZ, J. C.: op. cit., p. 159.

49 LONSDALE, R. W.: "West doorway, cathedral of Santiago de Compostella", The Architect. A weekly illustrated journal of art, civil engineering and building, $\mathrm{n}^{\circ} 23$, London, 5 june 1869, pp. 294-296. Posteriormente fue traducido al español por Inocencio Vilardebó : "Pórtico del Occidente de la catedral de Santiago de Compostela", Galicia Diplomática, I, n 36, 1883, p.259: "La figura que aparece en la base de la columna central arrodillada y mirando al Oriente es, según la tradición local, la efigie del Maestro Mateo".

${ }^{50}$ ÁLVAREZ DE LA BRAÑA, R.: Guía del viajero en Santiago, León, Establecimiento tipográfico de Miñón, 1875, p. 18: "Sin embargo la estatua del maestro mereció ser colocada al pie de la extrema columna que sostiene lo que hoy se llama nave de la Soledad. En ella cree el vulgo que golpeando las cabezas de los niños puede inspirarles elevados pensamientos y de ahí que sea conocido con el nombre de O Santo dos Croques".

${ }^{51}$ FORD, R.: A Handbook for Travellers in Spain and Readers at Home, London, John Murray, $5^{a}$ ed., 1878, pp. 242-243: "Las columnas descansan en una serie de monstruos que parecen simbolizar los vicios sometidos por los santos que están encima... En el bajo del pilar central que divide el pórtico, arrodillado hacia el interior, está la figura del arquitecto, Maestro Mateo, que lleva una cartela en la que está inscrita la palabra Architectus".

52 Como testimonio vid. VICUÑA, R. DE LA: "El Pórtico de la Gloria", Galicia Diplomática. Año 3, nº 14 (8 abril de 1888), p. 107: "Y mirando hacia la nave hay una estatua orante que representa al maestro Mateo, autor de tanta maravilla... Pero el vulgo menos escrupuloso que las autoridades eclesiásticas han canonizado al célebre arquitecto con el nombre de Santo dos Croques o Santo de los Chichones por asemejarse a estos los círculos que aparecen en su cabeza a modo de pelo crespo o ensortijado".

${ }^{53}$ FERNÁNDEZ SÁNCHEZ, J. M ${ }^{a}$ y FREIRE BARREIRO, F.: Santiago, Jerusalén, Roma. Diario de una peregrinación, T.I, Santiago, Boletín Eclesiástico, 1880, p. 77.

${ }^{54}$ Op. cit., pp. 134-135: "Terminaremos con un detalle que retrata al hombre y a la época. La imagen de Mateo, de aquel Arquitecto que levantó una de las puertas más bellas que el Cielo tenga sobre la tierra, está de rodillas, dando la espalda a su obra, y dirigiendo su mirada hacia el Altar mayor. El insigne Maestro aparece aún en edad robusta, con la barba afeitada, y la cabeza cubierta de espesa y rizada cabellera. Viste túnica de delgada y flexi- 
ble tela, y encima un no holgado manto sujeto sobre el hombro derecho por una muletilla formada de un pequeño rollo de piel. Las formas del rostro están bien acusadas y revelan energía de carácter y grandeza de ánimo; pero el corazón de Mateo era tan grande, como su cabeza. Con la mano izquierda sostiene un tarjetón, en que antiguamente, según algunos, estaba escrito: ARCHITECTVS (Arquitecto) y con la diestra se golpea el pecho, como si quisiera decir: "Si algo de bello hay, Señor, en la obra que está aquí detrás, vuestro es; lo que en ella hay de malo, es mío. Tened, Señor, piedad de mí, pecador".

55 Íd., íd., p. 135: "En una piedra que está enclavada en el pedestal de la columna, y a la altura del hombro derecho de Mateo, se ven grabadas estas letras: F E C, que parecen abreviatura de FECIT, (hizo)".

${ }^{56}$ Las dos inscripciones, de hecho, llegó a asociarlas (FECIT ARCHITECTUS) mucho después MELLINI, G. L.: El Maestro Mateo en Santiago de Compostela, Granada, Albaicín/Saeda Editores, 1968, s.p., aunque indicando que ya no se leían. No obstante, incide en la "leyenda" de Mateo y en su supuesto autorretrato que considera improbable pero, en cambio, muy propio de la mentalidad del siglo XIX. Estas son sus palabras: "La historia es interesante, porque aunque no es de esperar que nos provea de un autorretrato, alude sin embargo a un debate muy probable ligado al momento del descubrimiento de la puerta, el del retrato que, ciertamente, debía ser de una novedad desconcertante".

${ }^{57}$ Aquí también el estudio-relato de NEIRA DE MOSQUERA, A.: Op. cit., pp. 38-39 tuvo mucho que ver: "También el Cabildo compostelano detiene enfrente de esta imagen la procesión que en las grandes solemnidades recorre las naves de la Catedral antes de la misa mayor. Cumple de esta manera con la fundación de un prelado; pronuncia una conmemoración por el alma del arzobispo D. Pedro Muñiz, cuya sepultura está tan próxima a la estatua del maestro Mateo que esta efigie parece uno de los ángeles que colocaban de rodillas sobre los sepulcros antiguos, y que apartaron en alguna renovación de la lápida. Un destino providencial dirige algunas veces las obras del arte y las creaciones de la naturaleza. Dos hombres de esclarecido renombre, un prelado y un artista, que se apartaban del vulgo por sus elevados pensamientos, perito el primero en las ciencias ocultas y recluso de orden del Papa en el eremitorio de S. Lorenzo en 1218 , por dedicarse a la averiguación de las causas físicas y naturales, y tenido el segundo por impío y sin encontrar sitio donde colocar su cabeza por hacer un justo y merecido alarde de legítimo orgullo colocando el retrato al frente de la obra, se encuentran tan cerca que hasta el vulgo se ve precisado a reconocerlos de una sola mirada. Sobre la sepultura del arzobispo D. Pedro Muñiz se encuentra una lápida de bronce renovada en 1774, donde se lee esta invocación: COMPOSTELANUS PRESUL. PETRUS IIII FUISTI TE DIVINA MANUS PERDUCAT AD DEXTERAM XPTI". Dicho esto, quien mejor ha explicado esta relación orante-prelado ha sido, sin duda MORALEJO ÁlVAREZ, S.: "El 1 de abril de 1188. Marco histórico y contexto litúrgico en la obra del Pórtico de la Gloria", en El Pórtico de la Gloria: música, arte y pensamiento, Santiago, 1988, pp. 19-36. Indica, en efecto, que en un documento del 31 de marzo de 1214 ya aparece establecido el lugar para la sepultura del arzobispo "circa portam occidentalem que ex opposito rescipit altare"; que se enterró en este punto en 1224 en un sepulcro con su yacente de bronce. Dice a su vez que, pese a sus diferencias de material (piedra-bronce), se hace tentadora la hipótesis de una correlación entre ambas efigies, como si así el orante lo fuese a perpetuidad del sepulcro del arzobispo. No obstante, recuerda el autor, que la pérdida del yacente de D. Pedro y el desconocimiento de la relación exacta que pudo tener con el orante, nos impiden ir más allá de la conjetura. Cito por la reedición publicada en Patrimonio artístico de Galicia..., op. cit., II, p. 118. Sea como fuere, si en algún momento hubo alguna relación entre las dos figuras (penitente- yacente del prelado) sin duda fue buscada por el arzobispo (no por Mateo), enterrado allí años después de que fuese hecha la figura del "Santo dos Croques".
${ }^{58}$ VILLAAMIL Y CASTRO, J.: La catedral de Santiago..., op. cit., pp. 8586.

59 Ídem, ídem, pp. 85-86: "En una piedra enclavada en el pedestal de la columna, a la altura del hombro derecho de Mateo, están grabados FEC (fecit)".

${ }^{60}$ Vid. sobre el fotógrafo británico FONTANELLA, L.: Charles Thurston Thompson e o proxecto fotográfico ibérico, Santiago, Xunta de Galicia, 1996.

${ }^{61}$ Al respecto vid. MATEO SEVILLA, M.: El Pórtico..., op cit., especialmente pp. 49 y ss. También es de interés la consulta de VIGO TRASANCOS, A.: "Transformación, utopía y redescubrimiento. La catedral desde el Barroco hasta nuestros días", en M. Núñez Rodríguez (ed.): Santiago, la catedral y la memoria del arte, Santiago, Consorcio, 2000, especialmente pp. 220 y ss. y de FERNÁNDEZ RODRÍGUEZ, B.: "El Pórtico de la Gloria. Lugar de reflexión y encuentro. Años santos y restauraciones", en Santiago, ciudad de encuentros y presencias, coordinado por E. Fernández Castiñeiras y J. M. Monterroso Montero, Santiago, Consorcio-Alvarellos, 2012, pp. 73-99.

${ }^{62}$ Nos recuerda, en efecto, PEVSNER, N.: "The term Architect in the Middle Ages", Speculum, XVII, 1942, p. 556, que el término "Architectus" fue muy poco usado en la Edad Media para referirse a los maestros constructores.

${ }^{63}$ No obstante esta precisión hay algún caso excepcional que merece destacarse, como ocurre con Lanfranco, famoso maestro de obras de Módena, que aparece representado en una miniatura de la Relatio de innovatione ecclesiae Sancti Geminianiun señalado como "Lanfrancus architector" o con un tal "Fedantius architectus et magister edorum" que en el año 1010 aparece como testigo en un documento de San Cugat del Vallés. Vid. MARTínEZ DE AGUIRRE, J.: "Investigaciones sobre arquitectos y talleres de construcción en la España medieval cristiana", Anales de Historia del Arte, 2009, Volumen Extraordinario, p. 133. Por lo demás el artículo es también interesante por su generosa información sobre arquitectos y la práctica arquitectónica en la Edad Media española. 
${ }^{64}$ Incluso en la España del siglo XVI no fue habitual llamar "arquitecto" al maestro de obras o constructor como han demostrado MARÍAS, F.: El largo siglo XVI, Madrid, Taurus, 1989, pp. 496 y ss. y GÓMEZ URDÁÑEZ, C.: "Sobre el arquitecto vitruviano. De la Antigüedad al Renacimiento", en Carmen Lacarra Ducay (Coord.), La difusión del Arte romano en Aragón, Zaragoza, Institución Fernando el Católico (Diputación Provincial de Zaragoza), 1996, pp. 269 y ss.

${ }^{65}$ MARIÑO, B.: "La imagen del arquitecto en la Edad Media: historia de un ascenso", Espacio, Tiempo y Forma, Serie VII, $H^{\mathrm{a}}$ del Arte, t. 13, 2000, p. 13. También es de interés la consulta de CÓMEZ RAMOS, R.: Los constructores de la España medieval, p. 16 y POZA YAGÜE, M.: "El artista románico (canteros y otros oficios artísticos)", Revista Digital de Iconografía Medieval, vol. I, $n^{\circ}$ 2, 2009, pp. 9-22 (Consulta, el 8-agosto-2016).

66 Ídem, ídem.

${ }^{67}$ MACDONALD, W. L.: "Los arquitectos romanos", en KOSTOF, S. (Coor.), El arquitecto: historia de una profesión, Madrid, Cátedra, 1984, pp. 36-37 y 50.

${ }^{68}$ KOSTOF, S.: "El arquitecto en la Edad Media, en Oriente y Occidente", en KOSTOF, S. (Coor.), Op. cit., p. 66.

${ }^{69}$ WHITEHILL, W. M.: Liber Sancti Jacobi, "Codex Calixtinus", T. I, Santiago, Consejo Superior de Investigaciones Científicas, Instituto P. Sarmiento de Estudios Gallegos, 1944, p. 386: "Didascali lapicide qui prius beati lacobi basilicam edificaverunt nominabantur domnus Bernardus senex, mirabilis magister, et Rotbertus, cum ceteris lapicidibus circiter quinquaginta...". También Liber..., op. cit., pp. 604-605: "Los maestros canteros que empezaron a edificar la catedral de Santiago se llamaban don Bernardo el Viejo, maestro admirable, y Roberto, con otros cincuenta canteros poco más o menos que allí trabajaban asiduamente bajo la administración de los fidelísimos don Wicardo y don Segeredo, prior de la Canónica, y el abad don Gundesindo, en el reinado de Alfonso, rey de las Españas, y en el episcopado de don Diego primero, esforzadísimo guerrero y generoso varón".

70 Ídem, ídem.
71 "Eapropter ego Fernandus Dei gratia hispaniarum Rex ex amore Omnipotentis Dei... et ob reverentiam Sti. Jacobi, patroni nostri piissimi pro munere dono et concedo tibi magistro Matheo, qui operis praefati Apostoli primatum obtines et magisterium... Era MCCVI, Regnante Rege dno. Fernando Legione, Extremadura, Gallecia in Asturiis. Ego dns. F. Dei gratia hispaniarum Rex hoc scriptum quod fieri jussi proprio robore confirmo" Cit. por LLAGUNO Y AMIROLA, E.: Op. cit., I, doc. XX, p. 252. También en LÓPEZ FERREIRO, A.: Historia de la Santa A. M. Iglesia de Santiago de Compostela, IV, Santiago, 1901, pp. 93-94 de los apéndices.

72 "ANNO AB INCARNATIONE DNI MCLXXXVIII ERA ICCXXVI DIE KL. APRILIS SUPER LIMINARIA PRINCIPALIUM PORTALIUM ECCLESIAE BEATI JACOBI SUNT COLLACATA PER MAGISTRUM MATHAEUM QUI A FUNDAMENTIS IPSORUM PORTALIUM GESSIT MAGISTERIUM": "En el año de la Encarnación del Señor 1188, era 1226, en el día primero de abril, los umbrales de la portada principal de la iglesia del bienaventurado Santiago fueron colocados por el maestro Mateo, que dirigió la obra de la misma portada desde los cimientos". Cit. por ZEPEDANO Y CARNERO, J. $\mathrm{M}^{\mathrm{a}}$. : Op, cit., p. 182

73 VÁZQUEZ CASTRO, J.: "LOS maestros de obras y la construcción en Galicia durante la Edad Media", en J.A. Sánchez García y J.M. Yáñez Rodríguez (eds.): El aparejador y su profesión en Galicia. De los maestros de obra a los arquitectos técnicos, A Coruña, Consello Galego de Colexios de Aparelladores e Arquitectos Técnicos, 2001, pp. 26 y ss.

${ }^{74}$ VÁZQUEZ CASTRO, J. y CHAO CASTRO, D.: "A Idade Media", en Fontes escritas para a historia da arquitectura e do urbanismo en Galicia (séculos $X I-X X)$, coordinado por A. Vigo Trasancos, vol. I, Santiago, Xunta de Galicia, 2000, pp. 179-196.

75 Sobre la representación del arquitecto y su "retrato" en la iconografía medieval, así como otros aspectos relacionados con su visibilidad y ascenso social puede consultarse GALLET, Y.: "Autoportrait et représentation de soi au Moyen Âge: le cas de Matthieu d'Arras à la cathédrale Saint-Guy de Prague", en Gaucher-Rémond, E. (dir.): Autoportrait et représentation de I'individu, De Boeck Supérieur, Le Moyen Âge, t. 122, fasc. 1, 2016, pp. 41-64.

\section{${ }^{76}$ MARIÑO, B.: Op. cit., p. 14.}

77 Curiosamente, antes de esta data dos afamados escultores seiscentistas gallegos firmaron sus respectivas intervenciones en los coros de madera de las catedrales de Santiago y Lugo con sendas inscripciones en las que se autoproclaman respectivamente como "arquitectus" y "architectus": "JOANNES DAVILA ARQUITECTUS TUDEN DIOCESIS FECIT ANNO 1606" y "FRANCISCO A MOURE GALECUS CIVITATIS AURIENSIS INCOLLA CUI ULTIMA MANUS ACESIT ESCULPTOR ARCHITECTUS INVENIEBAT SCULPEBAT HOC OPUS ANNO DOMINI 1624". Con posterioridad Fernando de Casas y Novoa, en 1738, firmó su proyecto para la fachada de la catedral de Santiago como "arquitecto compostelano". Vid sobre esto y el papel de los arquitectos gallegos en el Barroco VIGO TRASANCOS, A.: BarroCo,..., op., cit., pp. 87-101.

${ }^{78} \mathrm{Como}$ obras de referencia sobre la Torre de Hércules vid. Ciudad y Torre. Roma y la llustración en A Coruña, coordinado por J. Ma Bello Diéguez y A. Vigo Trasancos, A Coruña, Ayuntamiento, 1991 y Torre de Hércules: Finis Terrae Lux. Simposio sobre los faros romanos y la navegación occidental en la Antigüedad, coordinado por F. Arias Vilas, C. Fernández Ochoa y A. Morillo, en Brigantium, 20, A Coruña, 2009.

${ }^{79}$ En efecto, tal como nos recuerda CORNIDE SAAVEDRA, J.: Investigaciones sobre la fundación y fábrica de la torre llamada de Hércules situada a la entrada del puerto de La Coruña, Madrid, Oficina de Benito Cano, 1792, pp. 36-42, el texto de la inscripción latina del faro coruñés, con algunos errores de transcripción, lo publicó por vez primera F. DE OCAMPO: Los cinco libros primeros de la Crónica general de España, Medina del Campo, Guillermo Millis, 1553, cap. XVII, fol. 41. A partir de aquí también la reprodujeron en sus libros Mauro Castellá Ferrer, Francisco de la Huerta y Vega, Fray Martín Sarmiento y otros muchos que trataron sobre el tema de la Torre de Hércules hasta bien 
entrado el siglo XIX; entre ellos VEDÍA Y GOOSSENS, E.: Historia y descripción de la ciudad de La Coruña, Coruña, Imprenta de D. Domingo Puga, 1845, p. 264.

${ }^{80} \mathrm{~A}$ punto de concluir este artículo han aparecido nuevos estudios que parecen insistir en la visión tradicional. Vid. VALLE PÉREZ, C.: "Reflexiones sobre el Maestro Mateo" (p.15) e YZQUIERDO PEIRÓ, R.: "El Maestro Mateo en la catedral de Santiago" (pp. 26-28), ambos en Maestro Mateo en el Museo del Prado, Madrid, Real Academia Galega de Belas Artes, Fundación Catedral de Santiago, Museo Nacional del Prado, 2016. Asimismo, insistiendo en el "retrato" de Mateo, pero aportando la peculiaridad de tratarse de un "retrato de humildad" y, a la vez, de una especie de "retrato a lo divino" por representarse el Maestro Mateo casi como si fuese San Mateo el Evangelista, también presente en el Tetramorfos del tímpano del Pórtico vid. CASTIÑEIRAS GONZÁLEZ, M.: "Autores homónimos: el doble retrato de "Mateo" en el Pórtico de la Gloria", en CASTIÑEIRAS GONZÁLEZ, M. (Ed.): Entre la letra y el pincel: El artista medieval, leyenda, identidad y estatus, El Ejido (Almería), Editorial Círculo Rojo, 2017, pp. 37-52.

81 Recientemente PRADO-VILAR, F.: "Stupor et mirabilia: el imaginario escatológico del maestro Mateo en el Pórtico de la Gloria", en El románico y sus mundos imaginados, Aguilar de Campoo, 2014, pp. 201-203, ha insistido en que el "Santo dos Croques" vendría a constituir una especie de glosa figurativa de la mención Architectus, pues, al parecer, tanto el epígrafe, en su fraseología, como el retrato, en su gestualidad, contienen referencias a la figura del "sapiens architectus" invocada por San Pablo en su primera carta a los corintios. Según esto el retrato del Maestro Mateo nos mostraría al arquitecto como un creador intelectual que, gracias a su sabiduría, devoción y entendimiento profundo de las Sagradas Escrituras conseguiría acceder a un modo de visión espiritual que se reflejaría en su obra. Mateo aparecería ensimismado, recreándose con los ojos del corazón en la visión interior del prototipo de su obra, que no sería otro que esa misma Ciudad Santa descrita por San Juan que estaba materializada, como si de una maqueta arquitectónica se tratase, frente a él, en la estructura del coro pétreo que ocupó los cuatro primeros tramos de la nave central hasta su desmantelamiento en el siglo XVII. En otras palabras, la efigie del Maestro Mateo sería, por tanto, una figura del creador en el sentido tipológico del término, más que un retrato en el sentido moderno, donde se entrelazan alusiones a una doble genealogía del artista, enraizada, por un lado, en las Sagradas Escrituras a través de referencias a modelos bíblicos del "sapiens architectus" al servicio de Dios, y, por otro, en la propia historia constructiva de la catedral de Santiago, jalonada por una serie de artífices de los que Mateo constituye la última generación, y a quienes esta figura también rinde homenaje, preservando su memoria, y la de la obra que se extiende majestuosa frente a él. Aparecería arrodillado al final de un camino que es también el final de la Historia. Mateo miraría así hacia la eternidad.Huelga decir que todo esto, tan rebuscado, podría tener algún sentido de ser el "Santo dos Croques" la imagen real de un arquitecto o de Mateo y de que hubiese existido alguna vez la palabra ARCHITECTUS en la cartela que lleva en su mano izquierda, argumento que, obviamente, no aceptamos por todo lo que venimos exponiendo en este artículo.

${ }^{82}$ WARD, M. L.: Op. cit., p. 116.

${ }^{3}$ NÚÑEZ RODRÍGUEZ, M.: "De la universalidad del pueblo elegido al valor del "credere"", en Santiago, la Catedral..., op. cit., pp. 103 y ss. También del mismo autor NÚÑEZ RODRÍGUEZ, M.: "El especulum morale de Alfonso IX a la luz del Pórtico de la Gloria", Potestas. Revista del Grupo Europeo de Investigación Histórica, N³, 2010, p. 71. La figura, vista así, simbolizaría el acto o gestus contrition del arrepentido en los pecados de la carne para así alcanzar el perdón.

${ }^{84}$ Con una cronología próxima al parecer a 1232, los tres peregrinos que aparecen arrodillados, con bordón y un curioso tocado en la cabeza podrían representar a tres destacados personajes, quizás a un rey, una reina y un obispo. Vid. CASTIÑEIRAS GONZÁlEZ, M.: "El Apóstol está presente: la estatua de
Santiago y sus peregrinos", en Imagens e liturgia na Idade Média, coordinado por Carla Varela Fernandes, Moscavide, Secretariado Nacional para os Bens Culturais da Igreja, 2015, especialmente $p$. 69 y ss. También, del mismo autor, "El Apóstol y sus adorantes peregrinos: el porqué de la imagen coral de Santiago de Turégano (Segovia)", en De peregrinatione. Studi in onore di Paolo Caucci von Saucken, a cura di Giuseppe Arlotta, Perugia, Edizioni Compostellane, 2016, pp. 749 y ss.

${ }^{85}$ Así se indica, en efecto, en el Capítulo XVII. Sermón del Santo papa Calixto en la solemnidad de la elección y de la traslación de Santiago Apóstol, que se celebra el día 30 de Diciembre: "No sin razón los que vienen a visitar a los santos reciben en la iglesia el báculo y el morral bendito. Pues cuando los enviamos con motivo de hacer penitencia al santuario de los santos, les damos un morral bendito, según el rito eclesiástico, diciéndoles: En nombre de nuestro Señor Jesucristo, recibe este morral hábito de tu peregrinación, para que castigado y enmendado te apresures en llegar a los pies de Santiago, adonde ansías llegar, y para que después de haber hecho el viaje vuelvas al lado nuestro con gozo, con la ayuda de Dios, quien vive y reina por los siglos de los siglos. Amén. También, cuando le damos el báculo, así decimos: Recibe este báculo que sea como sustento de la marcha y del trabajo, para el camino de tu peregrinación, para que puedas vencer las catervas del enemigo y llegar seguro a los pies de Santiago, y después de hecho el viaje, volver junto a nos con alegría, con la anuencia del mismo Dios, que vive y reina por los siglos de los siglos. Amén". Liber..., op., cit., p. 196.

${ }^{86}$ Sobre la indumentaria medieval vid. CARNICERO CÁCERES, A. y ALVIRA CABRER, M.: Guía de Indumentaria Medieval Masculina. Reyes y nobles en los Reinos Hispanos (1170 - 1230). http:// fidelisregi.com/Indumentaria_Medieval_Masculina_Nobles_en_los_reinos_ hispanos_1170_1230.pdf (consulta el 3-8-2016).

${ }^{87}$ En efecto, LÓPEZ PACHO, R.: El Pórtico de la Gloria, s.l., 1986, nota 5, dudó que el "Santo dos Croques" pudiese ser el autorretrato de Mateo y de que las letras de la inscripción y la 
cartela fuesen alusivas a FECIT ARCHITECTUS. En su opinión $\mathrm{FE}(\dot{\text { ) }}$ podría constituir un anagrama de FERNANDUS REX, en referencia clara a Fernando II, muerto precisamente en 1188 .

${ }^{8}$ CLAUSSEN, P. C.: "Zu Mateo und seiner Inschrift am Portico de la Gloria", en Santiago de Compostela. Pilgerarchitektur und bildliche Repräsentation in neuer Perspektive, herausgegeben von Bernd Nicolai / Klaus Rheidt, Bern, Peter Lang, 2015, p. 236.

89 Ídem, ídem, p. 236, nota 10.

90 Así se denomina ciertamente en dos ocasiones en el documento de 1168 en que vincula a Mateo como maestro vitalicio de la catedral compostelana. Vid. nota 71. Por otra parte, en opinión de RECUERO ASTRAY, M., ROMERO PORTILLA, P. y RODRÍGUEZ PRIETO, M ${ }^{\mathrm{a}}$ A.: Documentos medievales del Reino de Galicia: Fernando II (11551188), Santiago, Xunta de Galicia, 2000, p. XVII, el título de "Hispaniarum rex" Fernando II lo empezaría a usar en la documentación a partir de mediados de 1160, tras intervenir en Castilla durante la minoría de edad de su sobrino Alfonso VIII, mostrando así ciertas pretensiones hegemónicas.

${ }^{91}$ MORALEJO ÁlVAREZ, S.: El PórtiCO..., op. cit., II, p. 282.

92 Sobre la iconografía regia vid. MORALEJO ÁlVAREZ, S.: "La iconografía regia en el Reino de León (11571230)", en Il Curso de Cultura Medieval, Aguilar de Campoo, 1-6 octubre 1990, León, Centro de Estudios del Románico, 1992. Reproducido en Patrimonio artístico de Galicia..., II, op. cit., p. 161-171.

93 ROMA VALDÉS, A.: Moneda y sistemas monetarios en Castilla $y$ en León durante la Edad Media (10871366), Barcelona-Madrid, Asociación numismática española-Museo Casa de la Moneda, 2000, p. 102.

${ }^{94}$ Sobre los túmulos del panteón real de Santiago vid. MORALEJO ÁLVAREZ, S.: "¿Raimundo de Borgoña o Fernando Alfonso? Un episodio olvidado en la historia del Panteón Real compostelano", en Galicia en la Edad Media. Actas del Coloquio de Santiago de Compostela, 1987, Madrid, 1990, pp. 161-178. Reproducido en Patrimonio artístico de Galicia..., II, op. cit., pp. 173-182. Sobre la cuestión del panteón regio compostelano y la representación de los reyes vid. también NÚÑEZ RODRÍGUEZ, M.: Muerte coronada: el mito de los reyes en la catedral compostelana, Santiago, Universidade de Santiago de Compostela, 1999.

${ }^{95} \mathrm{El}$ tema de la barba, aparentemente menor, diferencia por grupos a los personajes del Pórtico tal y como ha demostrado MORALEJO ÁlVAREZ, S.: El Pórtico de la..., op. cit., II, p. 282. De hecho se distinguen las descomunales barbas de los patriarcas, las más afiladas de los profetas y las más cortas y cuidadas de los apóstoles, todas intentando transmitir una imagen diferente. En este sentido la del hombre con leones del parteluz parece ciertamente distinta, más salvaje y primitiva.

${ }^{96}$ SILVA, R. y BARREIRO FERNANDEZ, J. R.: El Pórtico de la Gloria. Autor e interpretación, Santiago, 1965, p. 112. Para Silva, ciertamente, la figura del hombre barbado del parteluz es un claro motivo sumerio: el héroe Gilgamés "que ha recorrido la Caldea como destructor de monstruos".

${ }^{97}$ Entre quienes más han insistido en la posibilidad de que la figura con leones fuese Adán están IGLESIA, A. DE LA: Op. cit., p. 155; VILLAAMIL Y CASTRO, J. (1866): Descripción..., op. cit., p.110; FITA, F. y FERNÁNDEZ-GUERRA, A.: Recuerdos de un viaje a Santiago de Galicia, Madrid, Imprenta de los Sres. Lezcano y compa., 1880, p. 86; VIDAL RODRÍGUEZ, M.: El Pórtico de la Gloria de la catedral de Santiago: explicación arqueológica y doctrinal, Santiago, I, 1926 , p. 29... y, más recientemente, YARZA LUACES, J.: Op. cit., p. 33; YZQUIERDO PERRÍN, R.: El maestro Mateo, Cuadernos de Arte Español, Historia 16, Madrid, 1992, p. 14; CARBÓ ALONSO, F.: El Pórtico de la Gloria. Misterio y sentido, Madrid, Encuentro, 2009, pp. 49 y 87 (su figura la justifica al ser Adán el padre de la humanidad, aunque lo interpreta como el "Hombre Nuevo" que habría superado su animalidad y sería salvado por el triunfo de Cristo) y, de nuevo, YZQUIERDO PERRÍN, R.: EI maestro Mateo y el Pórtico de la Gloria..., op. cit., pp. 43-44.

${ }^{98}$ VILLAAMIL Y CASTRO, J. (1868): La catedral..., art, cit, p.295; ZEPEDANO Y CARNERO, J. Ma: Op. cit., p. 177;
OTERO TÚÑEZ, R.: "Problemas de la catedral románica de Santiago", Compostellanum, vol. X, n 4, Santiago, 1965, pp. 973-974; YZQUIERDO PERRÍN, R.: "El maestro Mateo y la terminación de la catedral románica de Santiago", en M. C. Lacarra Ducay (coor.), Los caminos de Santiago: arte, historia y literatura, Zaragoza, Institución "Fernando el Católico", 2005, p. 262. Aunque no se refiere en concreto a la figura del forzudo compostelano MONTEIRA ARIAS, I.: "La propagande contre I'Islam dans la sculpture romane du chemin de Saint- Jacques", Compostelle. Cahiers d'Études de Recherche et d'Histoire Compostellanes, $n^{\circ}$ 9, 2006, p. 24, ha considerado recientemente que la representación de Sansón peleando con el león, en el contexto español, sería una alusión al mundo cristiano en su triunfo sobre el islam, basándose para ello en un texto sacado del "Poema de Fernán González". Posteriormente KELLER, S.: "Laster, Feindbilt und der polylobe Bogen: Die Kathedrale von Santiago de Compostela und der Islam", en Santiago de Compostela. Pilgerarchitektur und ..., op. cit., pp. 263-264, opta por considerar que el personaje del Pórtico junto con las restantes figuras animales y humanas del basamento puedan ser una representación simbólica del mal y lo pagano (quizá asociado al Islam) aquí aplastado por el mensaje cristiano que manifiesta la parte principal del Pórtico.

${ }^{99} \mathrm{Al}$ respecto vid. GARCÍA GARCÍA, F. de A.: "La Anástasis - Descenso a los infiernos", Revista Digital de ICOnografía Medieval, vol. III, nº 6, 2011, pp. 1-17 (Consulta, 26-agosto-2016).

${ }^{100}$ Esta iconografía ya la cuestionó YARZA LUACES, J.: Op. cit., p. 33.

101 Vid. REAU, L.: Iconografía del arte cristiano. Iconografía de la Biblia. Antiguo testamento, t. I, vol.1, Barcelona, ediciones del Serbal, 1996, p. 280.

${ }^{102}$ Con razón LÓPEZ PACHO, R.: Op. cit., s.p., aunque considera que la figura del basamento podría ser la representación de Sansón -pese a aparecer con dos leones y no con uno-, piensa más bien en un "Sansón pecador" al estar hermanado con los leones y, como ellos, aplastado por la arquitectura del Pórtico. 
103 "El maestro Mateo colocó a su Rey y Señor [Fernando II rey de León] en una actitud maravillosa para defender las puertas de la iglesia, mientras esta subsista, echado de bruces y con el pecho y cabeza levantados, incorporándose sobre un tarjetón... el cual sostiene sobre sus espaldas todo el peso del entrearco que gravita sobre el parteluz y como sostén de la Gloria de Dios, tiene un león debajo de cada brazo y con sus manos abre sus monstruosas fauces para convertirlos en figura de dos cañones para defensa de la Casa del Señor. Sobre él descansa el pilar de seis columnas enlazadas que sostienen el tímpano de la Gloria". Vid. D.B.C.F.A, (Bernardo Fernández), op. cit., p. 8.

104 Preferentemente PORTER, A. K.: La escultura románica en España, II, Barcelona, 1928, p. 66, n 929; PITA ANDRADE, J. M.: "Varias notas para la filiación artística de Maestre Mateo", Cuadernos de Estudios Gallegos, X, 1955, pp. 393-394; CASTIÑEIRAS GONZÁlEZ, M.: El Pórtico de la Gloria, op. cit., pp. 35-36; NÚÑEZ RODRÍGUEZ, M.: De la universalidad..., op. cit., $p$. 106; CASTIÑEIRAS GONZÁLEZ, M.: "O profeta Daniel na arte europea", en $O$ sorriso de Daniel, exposición dirigida por R. Villares, Santiago, Consello da Cultura Galega, 2004, pág. 179 y, más recientemente, OLAÑETA MOLINA, J. A.: "Modelos, programas e interpretación de la representación de Daniel en el foso de los leones como imagen alegórica de Cristo Triunfante en algunos hitos de la ruta jacobea", ad limina, VII, 2016, pp. 43-82.

105 Vid. sobre el tema GARCíA GARCÍA, F. de A.: "Daniel en el foso de los leones", Revista Digital de Iconografía Medieval, vol. I, n 1, 2009, pp. 1124 (Consulta, 24-agosto-2016).

${ }^{106} \mathrm{Vid}$ al respecto VIGO TRASANCOS, A.: "Tras las huellas de Hércules. La Estoria de Espanna, la Torre de Crunna y el Pórtico de la Gloria", Quintana, n 9 , 2010, pp. 226 y ss. El carácter juvenil y risueño del profeta lo pone también de manifiesto MORALEJO ÁLVAREZ, S.: El Pórtico..., op. cit., II, p. 282, al afirmar que en todas las versiones conocidas del "Ordo prophetarum", que al parecer influyó en la iconográfía del Pórtico, a Daniel se lo describe "etate iuvenis habito vero senex" o como "puer-senex"; es decir como "niño-maduro". Además por la Biblia sabemos también que el profeta se rió "et risi Daniel", cuando pudo demostrar al rey Ciro la superchería de los sacerdotes de Bel.

${ }^{107}$ De hecho se lo suele considerar una prefiguración de Cristo. Vid. REAU, L.: Op. cit., p. 447 y ss.

${ }^{108}$ CASTILLO, A. DEL: El Pórtico de la Gloria, Santiago, Bibliófilos gallegos, 1954, fig. 19

${ }^{109}$ MORALEJO ÁlVAREZ, S.: El Pórtico de la Gloria..., op. cit., Il, p. 284.

110 VIGO TRASANCOS, A.: Tras las huellas..., op. cit., pp. 218 y ss.

111 Vid. YARZA LUACES, J.: Op. cit., p. 6 y NICOLAl, Bernd: "From Transfiguration to Parousia. Examining the development of the West Portal of the Cathedral of Santiago de Compostela", en Santiago de Compostela. Pilgerarchitektur..., op. cit., p. 233.

112 MORALEJO ÁlVAREZ, S.: El 1 de abril de $1188 \ldots$, op. cit., Il, p. 117. Según este autor, los monarcas Fernando II y Alfonso IX, que descansan ambos en la Catedral, al patrocinar su construcción no hacían sino contribuir a la conclusión de su propio panteón dinástico y santuario "nacional". También fue habitual que los dos reyes aludan al Apóstol Santiago como a su patrono personal y de su reino. "En este sentido, cabe ver en el Pórtico el más claro eco hispano de los portails royaux franceses y no sólo en sus formas sino también en la ideología que en estos subyace".

${ }^{113}$ Las citan, entre otros, Pomponio Mela, en su Corografía, que fue escrita en el siglo I y las describe así: "Después hay un monte muy alto situado enfrente del que, al otro lado, se levanta en Hispania: Ilaman Abila a dicho monte, al otro Calpe y a los dos juntos Columnas de Hércules. Da cuenta la fama del origen legendario de esta denominación diciendo que fue el mismo Hércules quien separó los dos montes unidos anteriormente como una cordillera continua y que así fue como al Océano, contenido antes por la mole de los montes, se le dio entrada a los lugares que ahora inunda". Cit por BEJARANO, V. (Ed.): Hispania Antigua según Pomponio Mela, Plinio el Viejo y Claudio Ptolomeo, Barcelona, Instituto de Arqueología y Prehistoria, 1987, p.
104. También las menciona en el siglo V, OROSIO, P.: Historias (Libros I-IV), introducción, traducción y notas de Eustaquio Sánchez Salor, Madrid, Edit. Gredos, 1982, pp.86-87 (Historiarum adversum paganos libri septem): "Europa comienza, como ya dije, en el Polo Norte, desde el rio Tanais... El otro límite de Europa es el Océano Atlántico, en Hispania, sobre todo donde se divisan las Columnas de Hércules junto a las islas de Gades y donde las olas del Océano entran en las fauces del mar Tirreno". Otra narración distinta nos la proporciona, a principios del siglo VII, SAN ISIDORO DE SEVILLA: Etimologías, II, Madrid, 1982, pp. 145 y 193: "El estrecho gaditano debe su nombre a Cádiz, donde se encuentra el umbral del gran Mar en el que se separa del océano; por eso al llegar Hércules a Cádiz levantó allí unas columnas creyendo que allí se encontraba el fin del orbe de las tierras"... "Gadis es una isla situada en el confín de la provincia de Bética y separa Europa de África. En ella pueden verse las columnas de Hércules".

${ }^{114} \mathrm{El}$ primer escritor griego en relatar la lucha de Hércules con Gerión fue, al parecer, Hesíodo en su Teogonía escrita hacia los siglo VIII y VII a.C; pero es en la Geriónida de Estesícoro de Hímera, del s. VI a.C., cuando el episodio se sitúa en Tartessos, tradicionalmente considerado un reino o un territorio de la península Ibérica. La información sobre este tema es amplísima y obviamente escapa a nuestros propósitos; no obstante como obra de consulta que puede sintetizar y ayudar a entender toda su complejidad puede consultarse el documentado trabajo de GONZÁLEZ GARCÍA, F. J.: Hércules contra Gerión. Mitos y leyendas de la Torre de Hércules, 2 vols., Oleiros (A Coruña), Vía Láctea, 1997-1998, donde el lector podrán encontrar además muy amplia bibliografía.

${ }^{115}$ Dice así el texto de Mela: "Pegadas casi a estas costas....hay unas islas recientes... pero, dentre las que no conviene olvidar, la de Gades... y en una punta se asienta la ciudad del mismo nombre y en la otra está el templo de Hércules Egipcio, famoso por sus fundadores, por su veneración, por su antigüedad y por sus riquezas: lo erigieron los tirios; su santidad se debe a los 
huesos de Hércules allí depositados". Cit por BEJARANO, V. (Ed.): Op. cit., pp. 109-110. Por otra parte, en ciertos ambientes debía de estar bastante extendida la creencia de que Hércules había muerto en nuestro país tal como la recoge SAN ISIDORO DE SEVILLA: Op., cit., I, pág. 761: "Después de la muerte de Hércules en España, su ejército, integrado por gentes de distinta procedencia, al quedarse sin jefe, comenzó a errar en busca de un lugar en que asentarse".

116 JIMÉNEZ DE RADA, R.: Historia de los hechos de España, introducción, traducción, notas e índice de Juan Fernández Valverde, Madrid, Alianza editorial, 1989 (De Rebus Hipaniae, obra escrita hacia 1243).

${ }^{117}$ ALFONSO X EL SABIO: "Estoria de Espanna que fizo el muy noble rey don Alfonso fijo del rey don Fernando et de la reyna donna Beatriz", en Primera crónica general de España que mandó componer Alfonso el Sabio y se continuaba bajo Sancho IV en 1289, publicada por Ramón Menéndez Pidal, Madrid, 1955, 2 vols.

${ }^{118}$ ALFONSO X EL SABIO: General Estoria. Segunda parte, II, edición de Antonio G. Solalinde, Lloyd A. Kasten y Víctor R. B. Oelschläger, Madrid, CSIC, 1961.

${ }^{119}$ AL-RASI: Crónica del moro Rasis, versión del Ajbar Muluk al-Andalus de Ahmad ibn Muhammad ibn Musa AlRazi, 889-955; romanzada para el rey don Dionís de Portugal hacia 1300 por Mahomad, alarife, y Gil Pérez, clérigo de don Perianes Porçel, con estudios de Diego Catalán y Ma Soledad de Andrés, Madrid, 1974, Madrid, edit. Gredos, 1974, pp. 122-124: "E dizen que Espan, fijo de Jafed e nieto de Noe, tomo consejo con su mujer e con sus fijos sy fincarían en su tierra en que moravan o sy yrina para las otras tierras a buscar guarida. E tovieron por bien de no fincar ally.... E el metio toda su fazienda en aventura. E metiose en la mar en barcas e anduvieron tanto tiempo por la mar, fasta que llegaron a un rrio a que el puso nombre Ebro, porque a quel que lo consejo avia nombre Ebro. E aquel Ebro salio primera mente e fue catar que tierra era... E vio la tierra a su voluntad, e tornose para Espan e dixo- le. Señor, nos avemos aquí tan buena tierra como la de Ultramar. E entonces salio Espan e toda la otra gente con el. E ellos, después que todos ovieron el rrio pasado, començaron de fazer casas e de labrar e plantar, e tanto fizieron ellos e los otros que después vinieron que tovieron por bien de alçar a Espan por rrey, porque lo fallaron ombre de buen seso e de buenas maneras e muy esforçado. E después que lo fizieron rrey, dixoles: ¿Cómo ha nombre esta tierra de que me fazedes rrey? E eloos le rrespondieron. Tu, señor, nos traxiste a esta tuerra, e tu eres el primero rrey della e has nombre Yspan, tenemos por bien que aya nombre España. ... Desta ora en adelante se començo a poblar España".

${ }^{120}$ Según la fuente que se consulte a Espán se lo nombra también como Hispán, Hispano o Hispalo y se lo considera el héroe epónimo de España.

${ }^{121}$ AL-RASI: Op. cit., pp. 126-127. "Hercoles, quando sopo nuevas que España era poblada, aguiso sus conpañas e basteçio sus naves e vinose para España. E al primer lugar a que aportaron fue el puerto de Calid, aquel que después el poblo e fizo los conçilios. E andando Hercoles por España a su voluntad catando que tierra era, salió a el Helion, rrey de España [Gerion], con todas sus gentes, e lidio con Hercoles e con los griegos, e fue tal su ventura que lo mato Hercoles. E este Helion fue el postrimero rrey de los çinquenta y tres rreyes que vinieron del linaje desde Yspan... E en tal ora fue muerto el rrey Helion [Gerión], que nunca en España ovo después rrey del linaje de Yspan... Hercoles fue rrey griego, el mejor que nunca fue en Grecia, que nunca dexo tierra que el supiese a quel non fuese con su poder. E todos los conquisto".

122 Ídem, ídem, p. 128.

${ }^{123}$ Más información en VIGO TRASANCOS, A.: Tras las huellas..., op. cit., pp. 218 y ss.

124 Sobre el episodio del león de Nemea puede consultarse GRAVES, R.: Los mitos griegos, Barcelona, 2004, pp. 455 y ss. para su iconografía vid. PANDIELLO FERNÁNDEZ, M.: "Hércules", Revista Digital de Iconografía Medieval, vol. IV, no 8, 2012, pp. 67-78 (Consulta 24-agosto-2016).
${ }^{125}$ ALFONSO X EL SABIO: Estoria de Espanna..., op. cit., I, p. 8: "E segund cuenta la su estoria deste Hercules, desque ell ouo muerto el grand puerco montes dArcadia, mato al toro de Creta que era muy brauo e espauentable, e mato otrossi los tres leones amanos: ell uno en el mont Parthemio e los dos en la selua Nemea".

${ }^{126}$ ALFONSO X EL SABIO: General..., op. cit., II, pp. 7-8.

127 Sobre la miniatura vid. CÓMEZ RAMOS, R.: Las empresas artísticas de Alfonso $X$ el Sabio, Sevilla, Diputación, 1979, pp. 191-192; DOMíNGUEZ RODRÍGUEZ, A.: "Hércules en la miniatura de Alfonso X el Sabio", Anales de Historia del Arte, n 1, 1989, p. 96 y VIGO TRASANCOS, A.: Tras las huellas..., op. cit., p. 228. Se conserva en la Biblioteca del Real Monasterio de El Escorial, ms.Y.I.2, fol. 4 .

${ }^{128}$ Fue TATE, R. B.: Ensayos sobre la historiografía peninsular del siglo XV, Madrid, Gredos, 1970, p.17, el primer autor que, al hacer referencia a De Rebus Hispaniae de Jiménez de Rada (S. XIII), vio en el pasaje de Hércules la clave para lo que él denominó "una etnografía clásica de la monarquía española". Tras la lectura de la Crónica del moro Rasis (S. X) debe aceptarse que esta vinculación de nuestra monarquía con el héroe griego es mucho más antigua y tal vez provenga de viejas historias que remonten a una época anterior. Por lo tanto, basándose en estos conocimientos y en el convencimiento de que Hércules estaba en el origen de nuestra monarquía, no debe sorprender que el rey Alfonso X (1221-1284), tiempo después, viese en Hércules al más clásico y legendario fundador de la monarquía española. Sobre estas cuestiones puede consultarse también GÓNZÁLEZ GARCÍA, F. J.: Op. cit., vol. I, especialmente pp. 110 y ss. Por otra parte, en opinión de DOMÍNGUEZ RODRÍGUEZ, A.: op., cit., p. 96, la imagen del héroe griego presidió la decoración del Salón de Reyes del Alcázar de Segovia en tiempos del Rey Sabio y esa misma fue, al parecer, su intención cuando propuso ilustrar con múltiples retratos de nuestros reyes la Estoria de Espanna que, si se hubiese concluido, habría incluido también una amplia representación de escenas de la vida de Hércules. 
129 Sin querer ser, en modo alguno, exhaustivo, como ejemplos de la relación de la Monarquía española con Hércules en la Edad Moderna viene bien recordar que se constata en el Salón de Reinos del palacio del Buen Retiro donde se encontraban los trabajos de Hércules pintados por Zurbarán; en la Bóveda del Casón pintada por Luca Giordano que tenía bajo la cornisa asimismo todos sus trabajos; también nos consta que en el remate superior de la Torre del Rey del palacio real se instaló un busto del famoso héroe siguiendo el programa del Padre Sarmiento para servir de preámbulo a otras imágenes de Hércules que se prodigan en el interior del palacio. De hecho su presencia se destaca en uno de los semicírculos que se disponen bajo la bóveda de la escalera principal donde aparece la figura del héroe levantando las dos columnas de Gibraltar en presencia de Neptuno. No obstante, el más clamoroso tributo a Hércules en el Palacio Real se aprecia en la antecámara de Carlos III o pieza de conversación donde el rey cenaba, que tiene en su bóveda un fresco de Antonio Rafael Mengs con la representación de la Apoteosis de Hércules. Lleva la sala en las esquinas cuatro relieves ovales, obra de Felipe de Castro, que representan otros tantos trabajos del héroe: la sujeción del can Cerbero, el jabalí de Erimanto, la cierva de Cerinea y la hidra de Lerna. Vid. al respecto BROWN, J. y ELLIOTT, J. H.: Un palacio para el rey. El Buen Retiro y la corte de Felipe IV, Madrid, Alianza, 1981, pp.162 y ss. PONZ, A.: Viaje de España, VI, Madrid, Aguilar, 1988, pp. 284-285 y 290-291 y SANCHO, J. L.: Palacio real de Madrid, Madrid, Patrimonio nacional, 2004, p. 54. También VIGO TRASANCOS, A.: "Marte y Mercurio unidos por Hércules. El sueño ilustrado de un gran puerto hispano-indiano en el golfo de los ártabros (1720-1788)", en XVIII Congreso del CEHA. Mirando a Clío. El arte español. Espejo de su Historia, III, coordinado por $\mathrm{M}^{\mathrm{a}} \mathrm{D}$. Barral Rivadulla, E. Fernández Castiñeiras, B. Fernández Rodríguez y J. M. Monterroso Montero, Santiago, Servizo de Publicacións e Intercambio Científico, Universidade de Santiago de Compostela, 2012, especialmente pp. 2077 y ss.
${ }^{130}$ Que en el contexto que comentamos la relación de Hércules con España nos parezca la más apropiada, no excluye que en otros contextos Hércules pueda tener otras interpretaciones y significados. Vid. SENRA GABRIEL Y GALÁN, J. L.: "¿Hércules versus Cristo? una posible simbiosis iconográfica en el románico hispano", Quintana, 1, 2002, pp. 275-283. De hecho, lo habitual fue identificarlo con un personaje heroico asociado a la virtud, como un equivalente del propio Cristo o como representación de la victoria sobre el mal.

131 Obviamente, no podemos asegurar que los leones que se encuentran a los pies de la silla del Apóstol sean la versión domesticada de los fieros leones que aparecen en el basamento, aunque sería muy sugerente esta lectura; pero al mismo tiempo debe recordarse que en muchos ejemplares de sillas curules antiguas que han llegado hasta nuestros días es muy frecuente la presencia de cabezas de leones decorando los brazos y entendidas como un simple estándar ornamental sin mayores implicaciones.

${ }^{132}$ Así nos lo recuerda, en efecto, el Calixtino. Vid. Liber..., op. cit., pp. 167 y 190: ". . . a Juan le tocó Asia, que está ala derecha; a Santiago, España, que está a la izquierda en la división de las provincias". "Él no sólo predicó en Judea y Samaria, sino que vino a honrar a España y a Galicia, y a estas gentes, antes impías, con la virtud las transformó en la Iglesia de Cristo".

133 "MISIT ME DOMINUS". Cit. por VILLAAMIL Y CASTRO, J.: Descripción..., op. cit., p. 106.

134 "DEUS AUTEM INCREMENTUM DEDIT IN HAC REGIONE" cit. por. Ídem, ídem, p. 107. DÍAZ FERNÁNDEZ, J. Ma: Op. cit., pp. 29-30, nos recuerda que el texto pertenece a San Pablo, aunque retocado para la ocasión. De hecho, "las últimas palabras -in hac regione- ajenas al texto bíblico, son una concesión a lo circunstancial e histórico en el solar donde su cuerpo descansa después de haberlo fecundado con su predicación".

135 Vid. HERBERS, K.: "El Códice Calixtino. El libro de la iglesia compostelana", en Compostela y Europa. La historia de Diego Gelmírez, coordinado por M. Castiñeiras González, Milán, Skira, 2010, pp. 122-141.

$$
\begin{aligned}
& { }^{136} \text { Liber..., op. cit., p. } 168 . \\
& { }^{137} \text { Ídem, ídem. } \\
& { }^{138} \text { Íd., íd. p. } 220 . \\
& { }^{139} \text { Íd., íd. } \\
& { }^{140} \text { Íd., íd. p. } 219 . \\
& { }^{141} \text { Íd., íd., p. } 169 . \\
& { }^{142} \text { Íd., íd., p. } 168 . \\
& { }^{143} \text { Íd., íd., p. 169. Vid. también }
\end{aligned}
$$
MORALEJO ÁlVAREZ, S.: El Pórtico..., op. cit., II, p. 284

${ }^{144}$ Aunque esta precisión me parece poco relevante para la relación simbólica que se ha señalado, no olvido que, en el medio de la nave, se encontraba el viejo coro pétreo de Mateo que debió de levantarse entre 1188 y 1200 . Conviene recordar, no obstante, que la gran sillería de los canónigos compostelanos tenía una puerta abierta justo en el centro del trascoro que permitía el contacto visual de la figura arrodillada con el altar mayor y, en última instancia, siquiera en el plano simbólico, con la capilla principal de la cabecera dedicada al Salvador. Vid. sobre el coro OTERO TÚÑEZ, R. e YZQUIERDO PERRÍN, R.: El coro del maestro Mateo, A Coruña, Fundación Barrié, 1990, p. 79.

145 También es oportuno recordar que en la Estoria de Espanna del Alfonso $X$, de hacia 1270 , una mujer llamada Crunna habría dado nombre a la ciudad herculina de A Coruña por ser su primera pobladora. Vid. Op. cit., p. 9-10: "E mando [Hércules] en aquel logar fazer una torre muy grand, e fizo meter la cabega de Gerion en el cimiento, e mando poblar y una grand cibdat, e fazie escreuir los nombres de los omnes e de las mugeres que y uinien poblar, y el primero poblador que y uino fue una muger que auie nombre Crunna, e por essol puso assi nombre a la cibdat.".

$$
\begin{aligned}
& { }^{146} \text { Liber..., op. cit., p. } 219 . \\
& { }^{147} \text { Íd., íd., p. } 232 . \\
& { }^{148} \text { La alusión a estas miniaturas }
\end{aligned}
$$
medievales, que no iban citadas en el texto original, son fruto de la precisa orientación dada por mi desconocido revisor "por pares" que ha demostrado tener una amplia cultura iconográfica. Desde aquí mi agradecimiento.

${ }^{149}$ En las dos obras otonianas representan en concreto las provincias de Sclavinia, Germanía, Gallia y Roma. Más información en BANGO TORVISO, 
I. G.: "La imagen del emperador", en http://www.artehistoria.com/v2/contextos/3787.htm (consulta el 18 - abril - 2017).

150 Coincido con CASTIÑEIRAS GONZÁLEZ, M.: "El Maestro Mateo o la unidad de las artes", en Maestros del románico en el Camino de Santiago, Aguilar de Campóo, Fundación Santa María la Real, 2010, pp. 211-212 y 222 , en que quien dispuso el programa ideológico que ordena el Pórtico tuvo que ser necesariamente un canónigo culto de la basílica compostelana que disponía de un abundante material textual perfectamente adecuado a su labor. Y en este sentido el Calixtino, que compila tantos textos de exaltación jacobea, es indudable que debió de resultar una fuente determinante. Con razón dice DÍAZ FERNANDEZ, J. Ma: Op, cit., p. 23: "Pero si el Códice [Calixtino] ya estaba aquí cuando Fernando II llegó a Santiago y Maestro Mateo comenzó la obra, yo me pregunto por qué los textos teológicos del Códice no pudieron verse socorridos para el caso, tanto al menos como algunos de los títulos, ya bien conocidos, de la contemporánea biblioteca arzobispal".

${ }^{151}$ En relación con este protagonismo hegemónico de Fernando II señala D'EMILIO, J.: "The building and the pilgrims'guide", en Williams, J. y Stones, A. (eds.): The Codex Calixtinus and the shrine of St, James, Tübingen, Gunter Narr Verlag, 1992, pp. 197-198, que tuvo lugar sobre todo en los años en que ocupó el reino de Castilla su sobrino Alfonso VIII, menor de edad, y le arrebató a éste la ciudad de Toledo en 1162. Perdida de nuevo por el rey leonés la ciudad imperial en 1166, los intereses del monarca por Santiago se incrementaron de manera sustantiva, manifestándose de manera evidente en las obras llevadas a cabo en la fachada occidental.

${ }^{152}$ Así lo indica, de hecho, el propio monarca en un diploma de 1158 , el primero de ciento treinta y uno que él y su hijo Alfonso IX otorgaron a la iglesia compostelana: "A los que desean conservar y ampliar el reino de España se les ha de aconsejar que se empeñen en tener propicio al santísimo Santiago, patrono cierto y especial de los españoles". Cit. por LÓPEZ ALSINA, F.: "Merce- des reales a la iglesia de Santiago", en O Pórtico da Gloria e o seu tempo, op. cit., p. 179. También es aclaratorio el documento de 1168 en que el rey concede a Mateo una pensión vitalicia y que se encargue de las obras de la catedral: "Por eso yo, Fernando, por la gracia de Dios rey de las Españas, por amor al Dios Omnipotente por quien reinan los reyes, y reverencia al santísimo apóstol Santiago, nuestro piadosísimo patrón", cit. por VÁZQUEZ CASTRO, J. y CHAO CASTRO, D.: Op. cit., p. 55. Insiste en estas cuestiones MORALEJO ÁlVAREZ, S.: "El 1 de abril de 1188...", op. cit., II, p. 117. Según este autor, Fernando II al patrocinar la construcción del Pórtico no hacía sino contribuir a la conclusión de su propio panteón dinástico y santuario "nacional". Al mismo tiempo HERBERS, K: "La monarquía, el papado y Santiago de Compostela en el Medioevo", en Santiago de Compostela: ciudad y peregrino. Actas del $V$ congreso internacional de Estudios Xacobeos, Santiago, Xunta de Galicia, 2000, p. 112 nos recuerda que en este tiempo, según un documento del 21 de abril de 1183, el Apóstol y Compostela eran considerados cabezas del reino. También acepta estas opiniones NICOLAl, B.: op, cit., p. 225. Finalmente, no debemos olvidar que el patronazgo de Santiago tenía ya una vieja tradición en España que remontaba a la época asturiana. Al respecto vid. LÓPEZ ALSINA, F.: "Cabeza de oro refulgente de España: los orígenes del patrocinio jacobeo sobre el reino astur", en RUIZ DE LA PEÑA, J. I. (coor.), Las peregrinaciones a Santiago de Compostela y San Salvador de Oviedo en la Edad Media. Actas del Congreso Internacional celebrado en Oviedo del 3 al 7 de diciembre de 1990, Oviedo, Servicio de Publicaciones del Principado de Asturias, 1993, pp. 27-36.

153 "Et este rey Don Fernando de Leon, fijo dell Emperador et hermano del rey Don Sancho de Castiella, acabados ya con buen andança XXI anno de su regnado en su regno, fino en la villa de Benavent: et enterraronle en la eglesia de Sant Yague de Gallizia, cerca su abuelo el conde don Remond que yace $y$, et cerca la emperatriz donna Berenguella su madre...Et finco por heredero de Leon Don Alffonsso, fijo deste rey Don Fernando et de la reyna Doña Urra- ca, fija del rey don Alffonsso de Portugal". Cit. por ALFONSO X EL SABIO: La Estoria de Espanna..., op. cit., p. 676. Al parecer, contraviniendo inicialmente sus deseos de recibir sepultura en la catedral de Santiago de Compostela, fue enterrado en otro lugar, posiblemente en el Panteón de Reyes de San Isidoro de León, pues a su viuda, la reina Urraca, no le convenía trasladar los restos mortales a Santiago de Compostela, ya que su arzobispo, Pedro Suárez de Deza era partidario del rey Alfonso IX y no de la reina Urraca. Posteriormente, sus restos fueron trasladados por orden de su hijo Alfonso IX a la catedral compostelana. La traslación de los restos del rey Fernando II es mencionada en un diploma otorgado en Zamora por el rey Alfonso IX de León, y fechado el 4 de mayo de 1188 , en el que se certifica que los restos reales había sido trasladados a la catedral de Santiago de Compostela por orden de su hijo. https://es.wikipedia. org/wiki/Fernando_II_de_Le\%C3\%B3n (consulta el 7- agosto-2016).

${ }^{154} \mathrm{Al}$ respecto vid. PUENTE MlGUEZ, J. A.: "El sepulcro del conde Raimundo de Borgoña en la catedral de Santiago", en BARRAL RIVADULLA, M ${ }^{a}$ D. y LÓPEZ VÁZQUEZ, J. M.: Estudios sobre patrimonio artístico: homenaje del Departamento de Historia del Arte y de la Facultad de Geografía e Historia de la Universidad de Santiago de Compostela a la Prof. Dra. Ma del Socorro Ortega Romero, Santiago de Compostela, Xunta de Galicia, 2002, pp. 83-95 y GARCÍA GONZÁLEZ, S.: "El panteón regio compostelano. La pérdida de la memoria", en ALDEA CELADA, J. M. et al. (Coords.): Los lugares de la Historia, Salamanca, 2013, pp. 972-994.

${ }^{155}$ Vid. YZQUIERDO PERRÍN, R.: El maestro Mateo, op. cit., p. 10 y ВОТО VARELA, G., "Panthéons royaux des cathédrales de Saint- Jacques-de-Compostelle et de Palma de Mallorca. À la recherche d'un espace funéraire qui n'a jamais été utilisé », Espace ecclésial et liturgie au Moyen Age, A Baud (ed.), Lyon, 2010, pp. 285 y ss.

${ }^{156}$ Además de "rey de las España", Fernando II se proclamaba asimismo rey de León, de Galicia y Asturias y de Extremadura. Vid. nota 71 . 
Historia de una invención: realidad y ficción del supuesto autorretrato del Maestro Mateo

\section{REFERENCIAS}

Aldea Celada, José Manuel et al., ed. 2013. Los lugares de la Historia. Salamanca: Hergar Ediciones Antema.

Alfonso X el Sabio. 1955. "Estoria de Espanna que fizo el muy noble rey don Alfonso fijo del rey don Fernando et de la reyna donna Beatriz." In Primera crónica general de España que mandó componer Alfonso el Sabio y se continuaba bajo Sancho IV en 1289. 2 vols. Ed. by Ramón Menéndez Pidal, Madrid: Gredos.

Alfonso X el Sabio. 1961. General Estoria. Segunda parte, II. Ed. by Antonio G. Solalinde, Lloyd A. Kasten and Víctor R. B. Oelschläger. Madrid: Consejo Superior de Investigaciones Científicas.

Al-Rasi. 1974. Crónica del moro Rasis, versión del Ajbar Muluk al-Andalus de Ahmad ibn Muhammad ibn Musa Al-Razi, 889-955; romanzada para el rey don Dionís de Portugal hacia 1300 por Mahomad, alarife, y Gil Pérez, clérigo de don Perianes Porçel. Ed. by Diego Catalán and $\mathrm{M}^{\mathrm{a}}$ Soledad de Andrés. Madrid: Gredos.

Álvarez de la Braña, Ramón. 1875. Guía del viajero en Santiago. León: Establecimiento tipográfico de Miñón.

Andrade, Domingo de. 1695. Excelencias, antigüedad y nobleza de la Arquitectura. Santiago: Antonio Frayz.

Arias Anglés, Enrique. 1986. El paisajista romántico Jenaro Pérez Villaamil. Madrid: Consejo Superior de Investigaciones Científicas.

Arias Vilas, Fernando, Carmen Fernández Ochoa and Ángel Morillo, ed. 2009. Torre de Hércules: Finis Terrae Lux. Simposio sobre los faros romanos y la navegación occidental en la Antigüedad. Brigantium, 20. A Coruña: Museo Arqueolóxico e Histórico da Coruña.

Arlotta, Giuseppe, ed. 2016. De peregrinatione. Studi in onore di Paolo Caucci von Saucken. Perugia: Edizioni Compostellane.

Bango Torviso, Isidro. "La imagen del emperador." Accessed April 18, 1027. http://www. artehistoria.com/v2/contextos/3787.htm
Barral Rivadulla, María Dolores, and José Manuel López Vázquez, ed. 2002. Estudios sobre patrimonio artístico: homenaje del Departamento de Historia del Arte y de la Facultad de Geografía e Historia de la Universidad de Santiago de Compostela a la Prof. Dra. $M^{a}$ del Socorro Ortega Romero. Santiago de Compostela: Xunta de Galicia.

Barral Rivadulla, María Dolores, et al., ed. 2012. Mirando a Clío. El arte español. Espejo de su Historia, III. XVIII Congreso del CEHA. Santiago: Universidade de Santiago de Compostela.

Baud, Anne, ed. 2010. Espace ecclésial et liturgie au Moyen Age. Lyon.

Bejarano, Virgilio, ed. 1987. Hispania Antigua según Pomponio Mela, Plinio el Viejo y Claudio Ptolomeo. Barcelona: Instituto de Arqueología y Prehistoria.

Bello Diéguez, José María and Alfredo Vigo Trasancos, ed. 1991. Ciudad y Torre. Roma y la Ilustración en A Coruña. A Coruña: Ayuntamiento.

Boto Varela, Gerardo. 2010. "Panthéons royaux des cathédrales de Saint- Jacques-de-Compostelle et de Palma de Mallorca. À la recherche d'un espace funéraire qui n'a jamais été utilisé." In Espace ecclésial et liturgie au Moyen Age. Ed. by Anne Baud, 275-309. Lyon: Publications de la Maison de l'Orient et de la Méditerranée.

Bouza Brey, Fermín. 1959. “El maestro Mateo en la tradición popular de Galicia." Compostellanum 4: 181-194.

Brown, Jonathan, and John. H. Elliott. 1981. Un palacio para el rey. El Buen Retiro y la corte de Felipe IV. Madrid: Alianza.

Buschbeck, Ernst Heinrich. 1919. Der Pórtico de la Gloria von Santjago de Compostela. BerlínViena.

Carbó Alonso, Félix. 2009. El Pórtico de la Gloria. Misterio y sentido. Madrid: Encuentro.

Carnicero Cáceres, Alberto and Martín Alvira Cabrer. Guía de Indumentaria Medieval Masculina. Reyes y nobles en los Reinos Hispanos (1170 - 1230). Accessed August 3, 2016. http://fidelisregi.com/Indumentaria_Medie- 
val_Masculina_Nobles_en_los_reinos_hispanos_1170_1230.pdf

Castellá Ferrer, Mauro. 1610. Historia del Apóstol de lesus Christo Sanctiago Zebedeo, Patrón y Capitán General de las Españas. Madrid: Alonso Martín de Balboa.

Castillo, Ángel del. 1954. El Pórtico de la Gloria. Santiago: Bibliófilos gallegos.

Castiñeiras González, Manuel. 1999. El Pórtico de la Gloria. Madrid: San Pablo.

Castiñeiras González, Manuel. 2004. "O profeta Daniel na arte europea." In O sorriso de Daniel. Ed. by Ramón Villares, 31-45. Santiago: Consello da Cultura Galega.

Castiñeiras González, Manuel. 2010. “El Maestro Mateo o la unidad de las artes." In Maestros del románico en el Camino de Santiago, 187233. Aguilar de Campóo: Fundación Santa María la Real.

Castiñeiras González, Manuel. 2015. “El Apóstol está presente: la estatua de Santiago y sus peregrinos." In Imagens e liturgia na Idade Média. Ed. by Carla Varela Fernandes, 6388. Moscavide: Secretariado Nacional para os Bens Culturais da Igreja.

Castiñeiras González, Manuel. 2016. “El Apóstol y sus adorantes peregrinos: el porqué de la imagen coral de Santiago de Turégano (Segovia)." In De peregrinatione. Studi in onore di Paolo Caucci von Saucken. Ed. by Giuseppe Arlotta, 749-790. Perugia: Edizioni Compostellane.

Castiñeiras González, Manuel. 2017. "Autores homónimos: el doble retrato de "Mateo" en el Pórtico de la Gloria." Entre la letra y el pincel: El artista medieval, leyenda, identidad y estatus. Ed. by Manuel Castiéiras González, 37-52. El Ejido: Editorial Círculo Rojo.

Castiñeiras González, Manuel, ed., 2010. Compostela y Europa. La historia de Diego Gelmírez. Milán: Skira.

Castiñeiras González, Manuel, ed. 2017. Entre la letra y el pincel: El artista medieval, leyenda, identidad y estatus. El Ejido: Editorial Círculo Rojo.
Caveda, José. 1848. Ensayo histórico sobre los diversos géneros de arquitectura empleados en España desde la dominación romana hasta nuestros días, Madrid: Imprenta de D. Santiago Saunaque.

Ceán Bermúdez, Juan Agustín. 1800. Diccionario histórico de los más ilustres profesores de las bellas artes en España. III. Madrid: Imprenta de la viuda de Ibarra.

Claussen, Peter Cornelius. 2015. "Zu Mateo und seiner Inschrift am Portico de la Gloria." In Santiago de Compostela. Pilgerarchitektur und bildliche Repräsentation in neuer Perspektive. Ed. by Bernd Nicolai and Klaus Rheidt, 235-252. Bern: Peter Lang.

Cómez Ramos, Rafael. 1979. Las empresas artísticas de Alfonso X el Sabio. Sevilla: Diputación provincial.

Cómez Ramos, Rafael. 2006. Los constructores de la España medieval. Sevilla: Universidad.

Cornide Saavedra, Jose. 1792. Investigaciones sobre la fundación y fábrica de la torre llamada de Hércules situada a la entrada del puerto de La Coruña. Madrid: Oficina de Benito Cano.

D.B.C.F.A. (Bernardo Fernández). 1870. Reseña Histórica del Pórtico de la Gloria de la S. A. M. I. Catedral de Santiago. Santiago: Imprenta de Manuel Mirás.

D'Emilio, James. 1992. "The building and the pilgrims'guide." In The Codex Calixtinus and the shrine of St, James. Ed. By John Williams y A. Stones, .Tübingen: Gunter Narr Verlag.

Díaz Fernández, José María. 1993. “Teología del Pórtico de la Gloria." In Los instrumentos del Pórtico de la Gloria. Su reconstrucción y la música de su tiempo, I, ed. by José López Calo, 19-49. A Coruña: Fundación Barrié.

Domínguez Rodríguez, Ana. 1989. "Hércules en la miniatura de Alfonso X el Sabio." Anales de Historia del Arte 1: 91-99.

El románico y sus mundos imaginados. 2014. Aguilar de Campoo: Centro de Estudios del Románico.

Fernández Rodríguez, Begoña. 2012. “El Pórtico de la Gloria. Lugar de reflexión y encuentro. Años santos y restauraciones." In Santiago, 
ciudad de encuentros y presencias, ed. by E. Fernández Castiñeiras y J. M. Monterroso Montero, 73-99. Santiago: Consorcio-Alvarellos.

Fernández Sánchez, Jose María, and Francisco Freire Barreiro. 1880. Santiago, Jerusalén, Roma. Diario de una peregrinación, I. Santiago: Boletín Eclesiástico.

Fernando II de León. Accessed August 7, 2016. https://es.wikipedia.org/wiki/Fernando_II_de_ Le \%C3\%B3n

Fita, Fidel, and Aureliano Fernández-Guerra. 1880. Recuerdos de un viaje a Santiago de Galicia. Madrid: Imprenta de los Sres. Lezcano.

Fontanella, Lee. 1996. Charles Thurston Thompson e o proxecto fotográfico ibérico. Santiago: Xunta de Galicia.

Ford, Richard. 1845. A Handbook for Travellers in Spain and Readers at Home. London: John Murray.

Ford, Richard. 1878. A Handbook for Travellers in Spain and Readers at Home. 5a ed. London: John Murray.

Franco Mata, Ángela, ed. 2004. Patrimonio artístico de Galicia y otros estudios. Homenaje al prof. Dr. Serafín Moralejo Álvarez, 2 vols. Santiago: Xunta de Galicia.

Gallet, Yves. 2016. "Autoportrait et représentation de soi au Moyen Âge: le cas de Matthieu d'Arras à la cathédrale Saint-Guy de Prague." In Autoportrait et représentation de l'individu. Ed. by E. Gaucher-Rémond. De Boeck Supérieur, Le Moyen Âge, 122, nº 1: 41-64.

García García, Francisco de Asís. 2009. “Daniel en el foso de los leones." Revista Digital de Iconografía Medieval 1, no 1: 11-24. Accessed August 24, 2016. https://www.ucm.es/data/ cont/docs/621-2013-11-13-DanielFoso.pdf

García García, Francisco de Asís. 2011. "La Anástasis - Descenso a los infiernos." Revista Digital de Iconografía Medieval 3, no. 6: 1-17. Accesed August 26, 2016. https://www.ucm. es/data/cont/docs/621-2013-11-21-3.\%20 An\%C3\%A1stasis.pdf

García González, Sonsoles. 2013. "El panteón regio compostelano. La pérdida de la memoria."
In Los lugares de la Historia. Ed. by José Manuel Aldea Celada et al., 972-994. Salamanca: Hergar Ediciones Antema.

Gaucher-Rémond, Elisabeth, ed. 2016. Autoportrait et représentation de l'individu, De Boeck Supérieur, Le Moyen Âge, t. 122, fasc. 1.

Gómez Urdáñez, Carmen. 1996: "Sobre el arquitecto vitruviano. De la Antigüedad al Renacimiento." In La difusión del Arte romano en Aragón, ed. by Carmen Lacarra Ducay, 265-296. Zaragoza: Institución Fernando el Católico.

González García, Francisco Javier. 1997-1998. Hércules contra Gerión. Mitos y leyendas de la Torre de Hércules. Oleiros:Vía Láctea.

Graves, Robert. 2004. Los mitos griegos: BarceIona: Círculo de Lectores.

Herbers, Klaus. 2010. "El Códice Calixtino. El libro de la iglesia compostelana." In Compostela y Europa. La historia de Diego Gelmírez. Ed. by Manuel Castiñeiras González, 122-141. Milán: Skira.

Herbers, Klaus y Robert Plötz. 1999. Caminaron a Santiago. Relatos de peregrinaciones al "fin del mundo". Santiago: Xunta de Galicia.

Iglesia, Antonio de la. 1861. "Estudios arqueológicos. La gloria de la catedral de Santiago." Galicia. Revista universal de este reino, $\mathrm{n}^{\circ} 16$ : 242.

Iglesia, Antonio de la. 2008. Estudios arqueológicos. Ed. by María Rosa Saurín de la Iglesia. Madrid: Cuadernos de Estudios Gallegos, anexo XXXIX.

Inclán Valdés, Juan Miguel. 1833. Apuntes para la historia de la Arquitectura y observaciones sobre la que se distingue con la denominación de gótica. Madrid: Ibarra.

Isidoro de Sevilla. 1982. Etimologías, II. Madrid: Publicación católica.

Jiménez de Rada, Rodrigo. 1989. Historia de los hechos de España. Ed. by Juan Fernández Valverde. Madrid:Alianza editorial.

Juan. Apocalipsis. Accesed May 21, 2016. https:// www.iglesia.net/biblia/libros/apocalipsis.html 
Keller, Sarah. 2015. "Laster, Feindbilt und der polylobe Bogen: Die Kathedrale von Santiago de Compostela und der Islam." In Santiago de Compostela. Pilgerarchitektur und bildliche Repräsentation in neuer Perspektive. Ed. by Bernd Nicolai and Klaus Rheidt, 253-267. Bern: Peter Lang.

Kostof, Spiro. 1984. "El arquitecto en la Edad Media, en Oriente y Occidente." In El arquitecto: historia de una profesión, ed. by Spiro Kostof, 65-97. Madrid: Cátedra.

Kostof, Spiro, ed. 1984. El arquitecto: historia de una profesión. Madrid: Cátedra.

Lacarra Ducay, Carmen, ed. 1996. La difusión del Arte romano en Aragón. Zaragoza: Institución Fernando el Católico.

Lacarra Ducay, Carmen, ed. 2005. Los caminos de Santiago: arte, historia y literatura. Zaragoza: Institución "Fernando el Católico".

Laffi, Domenico. 1989. Viaggio in ponente a San Giacomo di Galitia a Finisterrae. Ed. by Anna Sulai Capponi. Perugia: Universitá.

Liber Sancti Jacobi. Codex Calixtinus. 1951. Traducción por los profesores A. Moralejo, C. Torres y J. Feo. Santiago: Instituto "Padre Sarmiento" de Estudios Gallegos.

Llaguno y Amirola, Eugenio. 1829. Noticias de los arquitectos y arquitectura en España desde su restauración, ilustradas y acrecentadas por D. Juan Agustín Ceán Bermúdez. I. Madrid: Imprenta Real.

Lonsdale, R. W. 1869. "West doorway, cathedral of Santiago de Compostella." The Architect. A weekly illustrated journal of art, civil engineering and building, no 23 (5 June): 294-296.

Lonsdale, R. W. 1883. "Pórtico del Occidente de la catedral de Santiago de Compostela" traducido al castellano por Inocente Vilardebó. Galicia Diplomática 1, no 36 (11 Marzo): 257-261.

López Alsina, Fernando. 1988: “Mercedes reales a la iglesia de Santiago." In O Pórtico da Gloria e o seu tempo, 179-180. Santiago: Xunta de Galicia.

López Alsina, Fernando. 1993. "Cabeza de oro refulgente de España: los orígenes del patrocinio jacobeo sobre el reino astur." In Las pe- regrinaciones a Santiago de Compostela y San Salvador de Oviedo en la Edad Media. Ed. by Juan Ignacio Ruiz de la Peña, 27-36. Oviedo: Servicio de Publicaciones del Principado de Asturias.

López Alsina, Fernando, ed. 2008. Alfonso IX e a súa época. Pro utilitate regni mei. A Coruña: Concello da Coruña.

López Calo, José, ed. 1993. Los instrumentos del Pórtico de la Gloria. Su reconstrucción y la música de su tiempo, I. A Coruña: Fundación Barrié.

López Ferreiro, Antonio. 1893. El Pórtico de la Gloria. Estudio sobre este célebre monumento de la basilica compostelana. Santiago de Compostela: Imprenta del Seminario Conciliar.

López Ferreiro, Antonio. 1901. Historia de la Santa A. M. Iglesia de Santiago de Compostela. IV. Santiago: Imprenta del Seminario Conciliar.

López Pacho, Ricardo. 1986. El Pórtico de la Gloria.

Macdonald, W. L. 1984. "Los arquitectos romanos." In E/ arquitecto: historia de una profesión, ed. by Spiro Kostof, 35-63. Madrid: Cátedra.

Maestro Mateo en el Museo del Prado. 2016. Madrid: Real Academia Galega de Belas Artes, Fundación Catedral de Santiago, Museo Nacional del Prado.

Maestros del románico en el Camino de Santiago. 2010. Aguilar de Campoo: Centro de Estudios del Románico.

Manual del viajero en la Catedral de Santiago. Reseña histórica. 1847. Madrid: Imprenta de Don Baltasar González.

Marías, Fernando. 1989. El largo siglo XVI. Madrid: Taurus.

Mariño, Beatriz. 2000: "La imagen del arquitecto en la Edad Media: historia de un ascenso." Espacio, Tiempo y Forma, Serie VII, Ha del Arte, 13: 11-25.

Martínez de Aguirre, Javier. 2009. "Investigaciones sobre arquitectos y talleres de construcción en la España medieval cristiana." Anales 
de Historia del Arte, Volumen Extraordinario: 127-163.

Mateo. Evangelio. Accessed August 21, 2016 https://www.sanpablo.es/libro-pueblo-dedios/la-biblia/nuevo-testamento/evangeliosegun-san-mateo/24

Mateo Sevilla, Matilde. 1991. El Pórtico de la Gloria en la Inglaterra Victoriana. La invención de una obra maestra. Santiago: Museo Nacional das Peregrinaciones.

Mateo Sevilla, Matilde. 1991. "El descubrimiento del Pórtico de la Gloria en la España del XIX." In Actas del Simposio Internacional sobre "O Pórtico da Gloria e a arte do seu tempo", 457-477. Santiago de Compostela: Xunta de Galicia.

Mellado, Francisco de Paula. 1850. Recuerdos de un viaje por Galicia en 1850. Madrid: Establecimiento tipográfico de Mellado.

Mellini, Gian Lorenzo. 1968. El Maestro Mateo en Santiago de Compostela. Granada: Albaicín/ Saeda Editores.

Mendoza de los Ríos, Pablo. 1731. Theatro Moral y Político de la Noble Academia Compostelana. Santiago.

Monteira Arias, Inés. 2006. "La propagande contre l'Islam dans la sculpture romane du chemin de Saint- Jacques." Compostelle. Cahiers d'Études de Recherche et d'Histoire Compostellanes 9: 10-36.

Moralejo Álvarez, Serafín. 1983. "La imagen arquitectónica de la catedral de Santiago de Compostela." In Atti del Convengo Internazionale di Studi: Il Pellegrinaggio a Santiago di Compostella e la Letteratura Jacopea. Perugia: 37-61. Reissued in Patrimonio artístico de Galicia y otros estudios. Homenaje al prof. Dr. Serafín Moralejo Álvarez. 2004. I. Ed. by Ángela Franco Mata, 237-246. Santiago: Xunta de Galicia.

Moralejo Álvarez, Serafín. 1985. "Le Porche de la Gloire de la Cathédrale de Compostelle: problèmes de sources et de interprètation." Les Cahiers de Saint-Michel de Cuxa (Julio): 92-110. Reissued in Patrimonio artístico de Galicia y otros estudios. Homenaje al prof. Dr. Serafín Moralejo Álvarez. 2004. I. Ed. by Án- gela Franco Mata, 307-318. Santiago: Xunta de Galicia.

Moralejo Álvarez, Serafín. 1988. “El 1 de abril de 1188. Marco histórico y contexto litúrgico en la obra del Pórtico de la Gloria." In El Pórtico de la Gloria: música, arte y pensamiento, 19-36. Santiago: Xunta de Galicia. Reissued in Patrimonio artístico de Galicia y otros estudios. Homenaje al prof. Dr. Serafín Moralejo Álvarez. 2004. II. Ed. by Ángela Franco Mata, 113-120. Santiago: Xunta de Galicia.

Moralejo Álvarez, Serafín. 1990. “¿Raimundo de Borgoña o Fernando Alfonso? Un episodio olvidado en la historia del Panteón Real compostelano." In Galicia en la Edad Media, 161178. Madrid: Sociedad Española de Estudios Medievales. Reissued in Patrimonio artístico de Galicia y otros estudios. Homenaje al prof. Dr. Serafín Moralejo Álvarez. 2004. II. Ed. by Ángela Franco Mata, 173-182. Santiago: Xunta de Galicia.

Moralejo Álvarez, Serafín. 1991. "Prólogo." In Mateo Sevilla, Matilde. El Pórtico de la Gloria en la Inglaterra Victoriana. La invención de una obra maestra, 11-19. Santiago: Museo Nacional das Peregrinaciones.

Moralejo Álvarez, Serafín. 1992. "La iconografía regia en el Reino de León (1157-1230)." In /I Curso de Cultura Medieval, Aguilar de Campoo, 1-6 octubre 1990. León: Centro de Estudios del Románico. Reissued in Patrimonio artístico de Galicia y otros estudios. Homenaje al prof. Dr. Serafín Moralejo Álvarez. 2004. II. Ed. by Ángela Franco Mata, 161-171. Santiago: Xunta de Galicia.

Moralejo Álvarez, Serafín. 1993. “El Pórtico de la Gloria." FMR, Franco María Ricci 199: 28-46. Reissued in Patrimonio artístico de Galicia y otros estudios. Homenaje al prof. Dr. Serafín Moralejo Álvarez. 2004. I. Ed. by Ángela Franco Mata, 281-284. Santiago: Xunta de Galicia.

Neira de Mosquera, Antonio. 1950. "Historia de una cabeza. 1188." In Monografías de Santiago y dispersos de temas compostelanos (18441852), by Antonio Neira de Mosquera, 27-42. Santiago de Compostela: Bibliófilos gallegos. 
Neira de Mosquera, Antonio. 1950. Monografías de Santiago y dispersos de temas compostelanos (1844-1852). Santiago de Compostela: Bibliófilos gallegos.

Neira de Mosquera, Antonio. 2000. Monografías de Santiago y dispersos de temas compostelanos (1844-1852). Ed. by José Daniel Buján. Santiago de Compostela:Ara Solis-Consorcio de Santiago.

Nicolai, Bernd. 2015. "From Transfiguration to Parousia. Examining the development of the West Portal of the Cathedral of Santiago de Compostela." In Santiago de Compostela. Pilgerarchitektur und bildliche Repräsentation in neuer Perspektive. Ed. by Bernd Nicolai and Klaus Rheidt, 213-233. Bern: Peter Lang. https://doi.org/10.3726/978-3-0351-0858$3 / 22$

Nicolai, Bernd, and Klaus Rheidt, ed. 2015. Santiago de Compostela. Pilgerarchitektur und bildliche Repräsentation in neuer Perspektive. Bern, Peter Lang. https://doi.org/10.3726/9783-0351-0858-3

Núñez Rodríguez, Manuel. 1999. Muerte coronada: el mito de los reyes en la catedral compostelana. Santiago: Universidade de Santiago de Compostela.

Núñez Rodríguez, Manuel. 2000. “De la universalidad del pueblo elegido al valor del "credere"." In Santiago, la Catedral y la memoria del Arte. Ed. by Manuel Núñez Rodríguez, 99129. Santiago: Consorcio.

Núñez Rodríguez, Manuel. 2010: “El especulum morale de Alfonso IX a la luz del Pórtico de la Gloria." Potestas. Revista del Grupo Europeo de Investigación Histórica, no 3: 69-98.

Núñez Rodríguez, Manuel, ed. 2000. Santiago, la catedral y la memoria del arte. Santiago: Consorcio.

O Pórtico da Gloria e a arte do seu tempo. 1991. Actas del Simposio Internacional celebrado en Santiago de Compostela, 3-8 de outubro de 1988. Santiago de Compostela: Xunta de Galicia.

O Pórtico da Gloria e o seu tempo. 1988. Catálogo da exposición conmemorativa do VIII centenario da colocación dos dinteis do Pórtico da
Gloria da Catedral de Santiago de Compostela. Santiago do 16 de setembro ó 17 de novembro de 1988. Santiago: Xunta de Galicia.

Ocampo, Florián de. 1553. Los cinco libros primeros de la Crónica general de España. Medina del Campo: Guillermo Millis.

Olañeta Molina, Juan Antonio. 2016. “Modelos, programas e interpretación de la representación de Daniel en el foso de los leones como imagen alegórica de Cristo Triunfante en algunos hitos de la ruta jacobea." Ad limina 7: 43-82.

Orosio. 1982. Historias (Libros I-IV). Ed. by Eustaquio Sánchez Salor. Madrid: Gredos.

Otero Túñez, Ramón. 1965. "Problemas de la catedral románica de Santiago". Compostellanum 10, no 4: 963-980.

Otero Túñez, Ramón, and Yzquierdo Perrín, Ramón. 1990. El coro del maestro Mateo. A Coruña: Fundación Barrié.

Pandiello Fernández, María. 2012. "Hércules." Revista Digital de Iconografía Medieval no 8: 67-78. Accesed August 24, 2016. https://www. ucm.es/data/cont/docs/621-2013-11-21H\%C3\%89RCULES. \%20Mar\%C3\%ADa\%20 Pandiello.pdf

Pevsner, Nicolaus. 1942. "The term Architect in the Middle Ages." Speculum 17, no 4 (October): 549-562. https://doi.org/10.2307/2856447

Pita Andrade, José Manuel. 1955. "Varias notas para la filiación artística de Maestre Mateo." Cuadernos de Estudios Gallegos 10: 373-403.

Ponz, Antonio. 1988. Viaje de España, VI. Madrid: Aguilar.

Porter, A. Kingsley. 1928. La escultura románica en España. II. Barcelona: Gustavo Gili.

Poza Yagüe, Marta. 2009. "El artista románico (canteros y otros oficios artísticos)." Revista Digital de Iconografía Medieval I, no 2: 2009: 9-22. Accesed August 8, 2016. https://www. ucm.es/data/cont/docs/621-2013-11-214.\%20Artista\%20rom\%C3\%A1 nico.pdf

Prado-Vilar, Francisco. 2014. "Stupor et mirabilia: el imaginario escatológico del maestro Mateo en el Pórtico de la Gloria." In El románico y 
sus mundos imaginados, 181-204. Aguilar de Campoo.

Puente Míguez, José Antonio. 2002. “El sepulcro del conde Raimundo de Borgoña en la catedral de Santiago." In Estudios sobre patrimonio artístico: homenaje del Departamento de Historia del Arte y de la Facultad de Geografía e Historia de la Universidad de Santiago de Compostela a la Prof. Dra. $M^{a}$ del Socorro Ortega Romero. Ed. by María Dolores Barral Rivadulla, and José Manuel López Vázquez, 83-95. Santiago de Compostela: Xunta de Galicia.

Rada y Delgado, Juan de la. 1860. Viaje de SS.MM. y AA. por Castilla, León, Asturias y Galicia, verificado en el verano de 1858. Madrid: Imprenta de Aguado.

Reau, Louis. 1996. Iconografía del arte cristiano. Iconografía de la Biblia. Antiguo testamento. I. 1. Barcelona: ediciones del Serbal.

Recuero Astray, Manuel, Paz Romero Portilla and María de los Ángeles Rodríguez Prieto. 2000. Documentos medievales del Reino de Galicia: Fernando I/ (1155-1188). Santiago: Xunta de Galicia.

Riobóo y Seijas, Antonio. 1747. Análysis histórica, chronologica de la primitiva erección, progresos y diversas reedificaciones de la Santa Iglesia de Santiago. Santiago: Imprenta de D. Andrés Frayz.

Roma Valdés, Antonio. 2000. Moneda y sistemas monetarios en Castilla y en León durante la Edad Media (1087-1366). Barcelona-Madrid: Asociación numismática española-Museo Casa de la Moneda.

Ruiz de la Peña, Juan Ignacio, ed. 1993. Las peregrinaciones a Santiago de Compostela y San Salvador de Oviedo en la Edad Media. Actas del Congreso Internacional celebrado en Oviedo del 3 al 7 de diciembre de 1990. Oviedo: Servicio de Publicaciones del Principado de Asturias.

Sánchez Ameijeiras, Rocío. 2008. "El entorno imaginario del rey: cultura cortesana y/o cultura clerical en Galicia en tiempos de Alfonso IX." In Alfonso IX e a súa época. Pro utilitate regni mei, 307-325. A Coruña: Concello da Coruña.
Sánchez García, Jesús Ángel, and José Manuel Yáñez Rodríguez, eds. 2001. El aparejador y su profesión en Galicia. De los maestros de obra a los arquitectos técnicos. A Coruña: Consello Galego de Colexios de Aparelladores e Arquitectos Técnicos.

Sancho, José Luís. 2004. Palacio real de Madrid. Madrid: Patrimonio nacional.

Schotborgh, Frans y Wolfgang Schlör. 1980. El Pórtico de la Gloria de Santiago de Compostela. Barcelona: Herder.

Senra Gabriel y Galán, José Luís. 2002. “ ¿Hércules versus Cristo? una posible simbiosis iconográfica en el románico hispano." Quintana 1: 275-283.

Silva, Rafael, and José Ramón Barreiro Fernández. 1965. El Pórtico de la Gloria. Autor e interpretación, A Coruña: Moret.

Stirling-Maxwell, William. 1848. Annals of the Artists of Spain. I. London: John Ollivier.

Street, George Edmund. 1865. Some Account of Gothic Architecture in Spain. London: John Murray.

Street, George Edmund. 1914. La arquitectura gótica en España. Madrid: Editorial Saturnino Calleja.

Taín Guzmán, Miguel. 1993. Comentario a las Excelencias, antigüedad y nobleza de la arquitectura de Domingo de Andrade. Santiago: Xunta de Galicia.

Tate, Robert Brian. 1970. Ensayos sobre la historiografía peninsular del siglo XV. Madrid: Gredos.

Valle Pérez, Carlos. 1988. "Mateo. Da Historia á lenda." In O Pórtico da Gloria e o seu tempo. Catálogo da exposición conmemorativa do VIII centenario da colocación dos dinteis do Pórtico da Gloria da Catedral de Santiago de Compostela, 195-196. Santiago: Xunta de Galicia.

Valle Pérez, Carlos. 2016. "Reflexiones sobre el Maestro Mateo." In Maestro Mateo en el Museo del Prado, 13-18. Madrid: Real Academia Galega de Belas Artes, Fundación Catedral de Santiago, Museo Nacional del Prado. 
Varela Fernandes, Carla, ed. 2015. Imagens e liturgia na Idade Média. Moscavide, Secretariado Nacional para os Bens Culturais da Igreja.

Vázquez Castro, Julio. 1998. “El rey de los incensarios. Víctor Hugo y el redescubrimiento romántico del Botafumeiro." Abrente 40-41: 149-186.

Vázquez Castro, Julio. 2001. "Los maestros de obras y la construcción en Galicia durante la Edad Media." In El aparejador y su profesión en Galicia. De los maestros de obra a los arquitectos técnicos. Ed. by Jesús A. Sánchez García y José Manuel Yáñez Rodríguez, 1992. A Coruña: Consello Galego de Colexios de Aparelladores e Arquitectos Técnicos.

Vázquez Castro, Julio, and David Chao Castro. 2000. "A Idade Media." In Fontes escritas para a historia da arquitectura e do urbanismo en Galicia (séculos XI-XX). Ed. by Alfredo Vigo Trasancos, I, 179-196. Santiago: Xunta de Galicia.

Vedía y Goossens, Enrique. 1845. Historia y descripción de la ciudad de La Coruña. A Coruña: Imprenta de D. Domingo Puga.

Vicuña, Ramón L. de. 1888. “El Pórtico de la Gloria." Galicia Diplomática 3, no 14 (8 Abril): 106-108.

Vidal Rodríguez, Manuel.1926. El Pórtico de la Gloria de la catedral de Santiago: explicación arqueológica y doctrinal .I. Santiago: El Eco Franciscano.

Vigo Trasancos, Alfredo. 1999. La catedral de Santiago y la llustración. Proyecto clásico y memoria histórica (1757-1808). Madrid: Electa-Consorcio.

Vigo Trasancos, Alfredo. 2000. “Transformación, utopía y redescubrimiento. La catedral desde el Barroco hasta nuestros días." In Santiago, la catedral y la memoria del arte, ed. by Manuel Núñez Rodríguez, 187-242. Santiago: Consorcio.

Vigo Trasancos, Alfredo. 2010. "Tras las huellas de Hércules. La Estoria de Espanna, la Torre de Crunna y el Pórtico de la Gloria." Quintana 9: 217-233.
Vigo Trasancos, Alfredo. 2012. Barroco. La arquitectura sagrada de antiguo reino de Galicia (1658-1763). Santiago: Consorcio-Teófilo.

Vigo Trasancos, Alfredo. 2012. "Marte y Mercurio unidos por Hércules. El sueño ilustrado de un gran puerto hispano-indiano en el golfo de los ártabros (1720-1788)." In Mirando a Clío. El arte español. Espejo de su Historia, III. Ed. by María Dolores Barral Rivadulla, et al., 17301751. Santiago: Universidade de Santiago de Compostela.

Villaamil y Castro, José. 1866. Descripción histórico-artístico-arqueológica de la catedral de Santiago. Lugo: Imprenta de Soto Freire.

Villaamil y Castro, José. 1868. “La catedral de Santiago. Su historia y descripción, sus accesorios y mobiliario." El arte en España. Revista mensual del arte y de su historia 7: 296.

Villaamil y Castro, José. 1909. La catedral de Santiago. Breve descripción histórica. Madrid: Tipografía de la revista de Archivos.

Villares, Ramón, ed. 2004. O sorriso de Daniel. Santiago: Consello da Cultura Galega.

Ward, Michel Lauer. 1986. Studies of the Portico de la Gloria at the catedral of Santiago de Compostela. Ann Arbor: University Microfilm International.

Whitehill, Walter Muir. 1944. Liber Sancti Jacobi, "Codex Calixtinus", I. Santiago: Consejo Superior de Investigaciones Científicas. Instituto Padre Sarmiento de Estudios Gallegos.

Williams, John, and A. Stones, ed. 1992. The Codex Calixtinus and the shrine of St, James. Tübingen: Gunter Narr Verlag.

Yarza Luaces, Joaquín. 1984. El Pórtico de la Gloria. Madrid: Alianza editorial.

Yzquierdo Perrín, Ramón. 1992. El maestro Mateo. Cuadernos de Arte Español. Madrid: Historia 16.

Yzquierdo Perrín, Ramón. 2005. “El maestro Mateo y la terminación de la catedral románica de Santiago." In Los caminos de Santiago: arte, historia y literatura. Ed. by María del Carmen Lacarra Ducay, 253-284. Zaragoza: Institución "Fernando el Católico". 
Historia de una invención: realidad y ficción del supuesto autorretrato del Maestro Mateo

of Yzquierdo Perrín, Ramón. 2010. El maestro Ma-

C teo y el Pórtico de la Gloria en la catedral de Santiago. León: Edilesa.

Yzquierdo Peiró, Ramón. 2016. “El Maestro Mateo en la catedral de Santiago." In Maestro Mateo en el Museo del Prado, 19-52. Madrid: Real Academia Galega de Belas Artes, Fun- dación Catedral de Santiago, Museo Nacional del Prado.

Zepedano y Carnero, José María. 1870. Historia y descripción arqueológica de la basílica compostelana. Lugo: Imprenta de Soto Freire. Reissued in 1999. Santiago: Xunta de Galicia. 